\title{
DIAGNOSE NUTRICIONAL E RESPOSTAS DO CAPIM-BRAQUIÁRIA SUBMETIDO A DOSES DE NITROGÊNIO E ENXOFRE
}

\author{
ANACLETO RANULFO DOS SANTOS \\ Engenheiro Agrônomo
}

Orientador:Prof. Dr. FRANCISCO ANTONIO MONTEIRO

Tese apresentada à Escola Superior de Agricultura "Luiz de Queiroz", da Universidade de São Paulo, para obtenção do titulo de Doutor em Agronomia, Área de Concentração: Solos e Nutrição de Plantas.

$P \mid R A C I C A B A$

Estado de São Paulo-Brasil

Dezembro -1997 
Dados Internacionais de Catalogaçāo na Publicaçāo (CIP) DIVISÃo DE BIBLIOTECA E DOCUMENTAÇĀO - Campus "Luiz de Queiroz"/USP

Santos, Anacleto Ranulfo dos

Diagnose nutricional e respostas do capim-braquiária submetido a doses de nitrogênio e enxofre / Anacleto Ranulfo dos Santos. - - Piracicaba, 1997.

115 p. : il.

Tese (doutorado) - Escola Superior de Agricultura Luiz de Queiroz, 1997.

Bibliografia.

1. Capim braquiária 2. Diagnose 3. Enxofre 4. Graninea forrageira 5. Matéria seca 6. Nitrogênio 7. Nutrição vegetal 


\section{DIAGNOSE NUTRICIONAL E RESPOSTAS DO CAPIM-BRAQUIÁRIA SUBMETIDO A DOSES DE NITROGÊNIO E ENXOFRE}

ANACLETO RANULFO DOS SANTOS

Aprovada em: 09/01/1998

Comissão julgadora:

Prof. Dr. Francisco Antonio Monteiro

ESALQ/USP

Prof. Dr. Sila Carneiro da Silva ESALQ/USP

Prof. Dr. Takashi Muraoka CENAIUSP

Prof. Dr. Joaquim Carlos Werner

IZISAA

Prof. Dr. Luis Roberto de Andrade Rodrigues

FCA/UNESP

Prof. Dr. FRANCISCO ANTONIO MONTEIRO Orientador 
Aos meus pais José Ranulfo e Adelaide, aos meus irmãos e cunhados,

\section{OFEREÇO}

A minha esposa DORA e aos nossos filhos CAMILO e FELIPE, 


\section{AGRADECIMENTOS}

Ao Prof. Dr. Francisco Antonio Monteiro pela excelente orientação, incentivo, convivência e confiança apresentada.

Ao Prof. Dr. Antonio Roque Dechen pela amizade sincera, incentivo, apoio e confiança.

Ao Prof. Dr. Quirino Augusto de Camargo Carmello pela amizade, apoio e incentivo.

A todos os demais professores do Curso de Solos e Nutrição de Plantas pelos conhecimentos transmitidos e amizade firmada.

Ao Pesquisador José Guilherme de Freitas do Instituto Agronômico de Campinas, pela colaboração na utilização do clorofilômetro e amizade.

Às Bibliotecárias Eliana M. Garcia Sabino e Kátia M. Andrade Ferraz pela ajuda na correção das referências bibliográficas.

Aos estagiários do Setor de Nutrição de Plantas pela colaboração nos trabalhos e amizade firmada.

Aos funcionários do Laboratório de Nutrição Mineral de Plantas, Edinéia C.S. Mandoni, Fernando E. Ré, Lúcia H.S.P. Forti, Lurdes A.D. de González, Mirtes V. Sesso, Nivanda M. de Moura e Sueli M.A.C. Bovi e a estagiária Giovana M. de Oliveira, pelo expressivo apoio.

Aos colegas de curso e amigos, especialmente Ana Aparecida da Silva, Beatriz Dias Corrêa, João Batista Rodrigues de Abreu e Waldssimiler Teixeira de Mattos pela amizade sincera, ajuda e incentivo constante.

À Universidade Federal da Bahia - Escola de Agronomia, pela oportunidade concedida para realização deste curso.

À CAPES pelo apoio financeiro e institucional prestado para a 
realização deste trabalho.

À Universidade de São Paulo - Escola Superior de Agricultura "Luiz de Queiroz" pelo oferecimento deste Curso de Pós-Graduação. 


\section{SUMÁRIO}

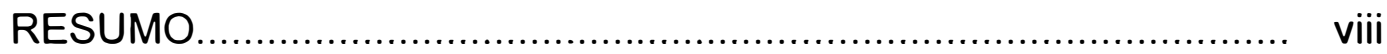

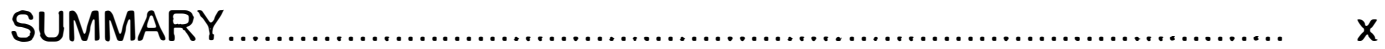

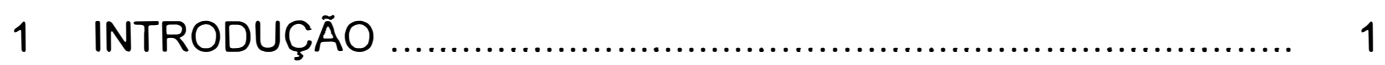

2 REVISÃO DE LITERATURA _.............................................. 3

2.1 Brachiaria decumbens Stapf. ................................................. 3

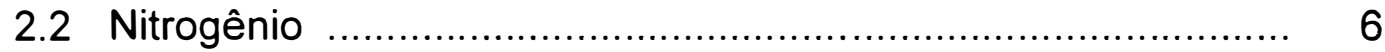

2.3 Nitrogênio no capim-braquiária ............................................... 8

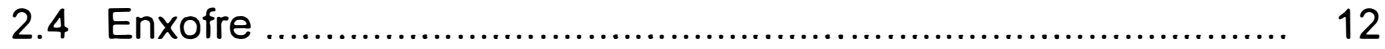

2.5 Enxofre no capim-braquiária ............................................ 15

2.6 Relação nitrogênio:enxofre .............................................. 17

2.7 Perfilhamento do capim-braquiária......................................... 19

2.8 Atividade da redutase do nitrato ........................................ 22

2.9 Teor de clorofila no capim-braquiária...................................... 24

2.10 Nivel crítico e sintomatologia de deficiência de nitrogênio e

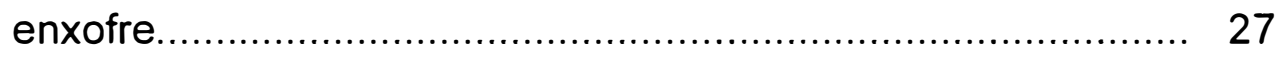

3 DIAGNOSE NUTRICIONAL E RESPOSTAS DO CAPIMBRAQUIÁRIA SUBMETIDO A DOSES DE NITROGÊNIO ......... 30

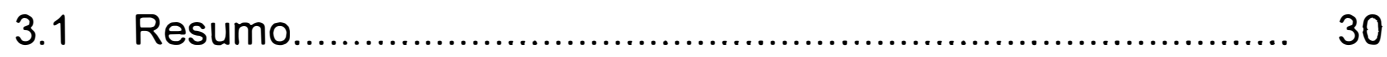

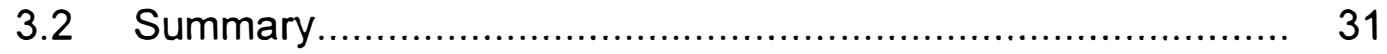

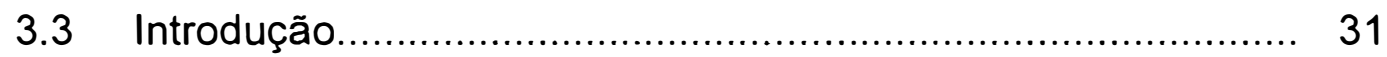

3.4 Material e métodos....................................................... 34

3.4.1 Localização e espécie forrageira........................................... 34

3.4.2 Doses de nitrogênio, soluções nutritivas e delineamento experimental. 
3.4.3 Instalação e condução do experimento..................................... 35

3.4.4 Produção de matéria seca ................................................... 36

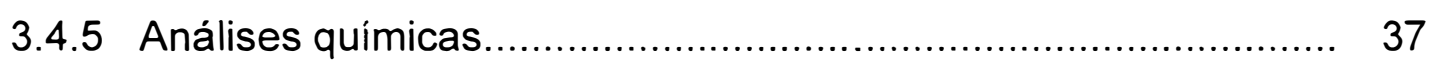

3.4.6 Análises estatísticas........................................................ 38

3.5 Resultados e discussão..................................................... 39

3.5.1 Produção de matéria seca ................................................ 39

3.5.2 Número de perfilhos no capim-braquiária................................ 42

3.5.3 Atividade da redutase do nitrato............................................. 46

3.5.4 Estimativa do teor de clorofila através do valor SPAD.............. 49

3.5.5 Concentração de nitrogênio nos componentes da parte aérea 51

3.5.6 Concentração de nitrogênio nas raizes .................................. 54

3.5.7 Acúmulo de nitrogênio nos componentes da planta................. 55

3.5.8 Nivel crítico de nitrogênio no capim-braquiária.......................... 58

3.5.9 Relação do teor de $\mathrm{N}$ e valor SPAD no capim-braquiária ......... 60

3.5.10 Sintomatologia de deficiência de nitrogênio............................... 62

3.6 Conclusões....................................................................... 63

4 DIAGNOSE NUTRICIONAL E RESPOSTAS DO CAPIMBRAQUIÁRIA SUBMETIDO A DOSES DE ENXOFRE .................. 64

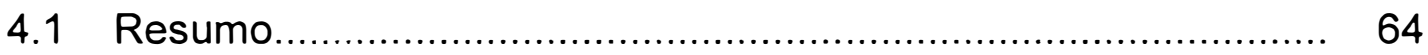

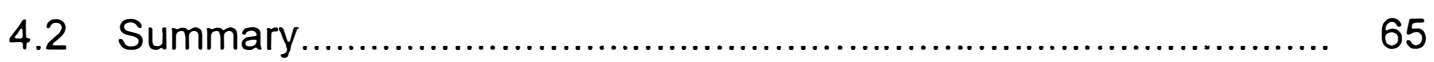

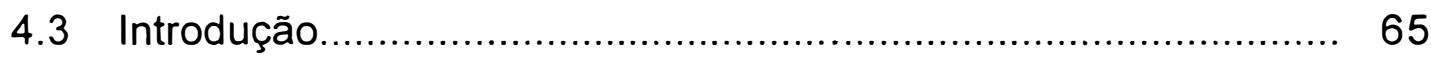

4.4 Material e métodos............................................................. 67

4.4.1 Localização e espécie forrageira............................................. 67

4.4.2 Doses de enxofre, soluções nutritivas e delineamento

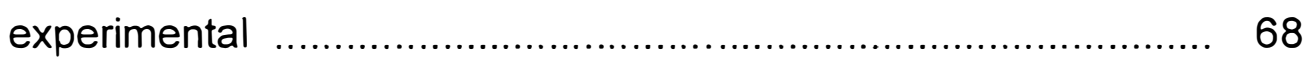

4.4.3 Instalação e condução do experimento....................................... 69 
4.4.4 Produção de matéria seca................................................... 70

4.4.5 Análises químicas........................................................... 70

4.4.6 Análises estatísticas...................................................... 72

4.5 Resultados e discussão.................................................... 72

4.5.1 Produção de matéria seca ................................................ 72

4.5.2 Número de perfilhos no capim-braquiária .............................. 76

4.5.3 Atividade da redutase do nitrato........................................... 77

4.5.4 Estimativa do teor de clorofila através do valor SPAD............. 80

4.5.5 Concentração de enxofre nos componentes da parte aérea...... 82

4.5.6 Concentração de enxofre nas raízes ....................................... 86

4.5.7 Acúmulo de enxofre nos componentes da planta..................... 87

4.5.8 Relação N:S no capim-braquiária.......................................... 91

4.5.9 Nível crítico de enxofre no capim-braquiária............................ 93

4.5.10 Sintomatologia de deficiência de enxofre ............................... 96

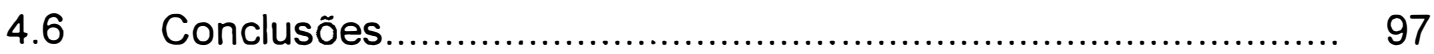

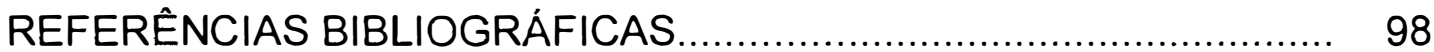




\title{
DIAGNOSE NUTRICIONAL E RESPOSTAS DO CAPIM-BRAQUIÁRIA SUBMETIDO A DOSES DE NITROGÊNIO E ENXOFRE
}

\author{
Autor: ANACLETO RANULFO DOS SANTOS \\ Orientador: Prof. Dr. FRANCISCO ANTONIO MONTEIRO
}

\section{RESUMO}

Foram realizados dois experimentos em casa-de-vegetação com o capim-braquiária (Brachiaria decumbens Stapf. cv. Basilisk) cultivado em solução nutritiva, utilizando sílica como substrato. O primeiro experimento foi desenvolvido no periodo dezembro de 1995 a fevereiro de 1996 e foram avaliadas oito doses de nitrogênio $\left(0 ; 14 ; 42 ; 126 ; 210 ; 294 ; 378\right.$ e $462 \mathrm{mg} \mathrm{L}^{-1}$ ). O segundo experimento foi desenvolvido no periodo de outubro a dezembro de 1996 e foram utilizadas oito doses de enxofre $(0 ; 2 ; 4 ; 16 ; 32 ; 48 ; 64$ e 80 $\mathrm{mg} \mathrm{L}^{-1}$ ). Os estudos tiveram como objetivos avaliar os efeitos do nitrogênio e do enxofre na produção de matéria seca. no número de perfilhos, na atividade da redutase do nitrato, no teor de clorofila, na concentração e no acúmulo de cada elemento estudado nos componentes da planta e estabelecer parâmetros para determinação do nivel crítico desses nutrientes nessa forrageira.

Em cada um dos experimentos foi utilizado o delineamento de blocos completos ao acaso, com quatro repetições. No primeiro experimento, o primeiro corte das plantas ocorreu aos 39 dias após o transplante para os vasos e o segundo corte aos 31 dias após o primeiro corte. No segundo 
experimento, as plantas foram colhidas aos 40 dias após o transplante para os vasos e novamente 30 dias após o primeiro corte. Nos dois experimentos as plantas foram separadas em folhas não-expandidas, lâminas de folhas novas, lâminas de folhas velhas e colmos+bainhas. Após o segundo corte as raizes também foram coletadas.

No primeiro experimento as doses de nitrogênio proporcionaram aumentos na produção de matéria seca da parte aérea e das raízes e no número de perfilhos do capim-braquiária. A atividade da redutase do nitrato e 0 teor de clorofila também foram influenciados pelo nitrogênio da solução. A concentração de nitrogênio foi mais baixa nos colmos+bainhas que nos demais componentes da parte aérea da forrageira. As lâminas de folhas novas mostraram-se as mais indicadas para a avaliação do estado nutricional de nitrogênio no capim-braquiária e o nível crítico de nitrogênio nessas lâminas está entre 14,5 e $22 \mathrm{~g} \mathrm{de} \mathrm{kg}^{-1}$ de matéria seca.

No segundo experimento, as doses de enxofre proporcionaram aumentos na produção de matéria seca no capim-braquiária e influenciaram no número de perfilhos no segundo cultivo. A atividade da redutase do nitrato e o teor de clorofila, nos dois crescimentos da forrageira, foram alterados pelas doses de enxofre na solução. A concentração de enxofre foi mais baixa nos colmos+bainhas nas doses mais baixas e nas lâminas de folhas novas nas doses mais altas de enxofre na solução, no primeiro crescimento. No segundo período do cultivo, a mais alta concentração de enxofre ocorreu nas lâminas de folhas velhas com exceção da dose mais alta avaliada. O acúmulo de enxofre foi menor nas folhas não-expandidas e maior nos colmos+bainhas, nos dois crescimentos do capim-braquiária. As lâminas de folhas novas revelaram-se as mais indicadas para a avaliação do estado nutricional de enxofre no capimbraquiária e o nível crítico de enxofre nelas está entre 0,81 a $1,0 \mathrm{~g} \mathrm{de} \mathrm{S} \mathrm{kg}^{-1}$ de matéria seca. 


\title{
NUTRIENT DIAGNOSIS AND RESPONSES OF Brachiaria decumbens TO NITROGEN AND SULFUR RATES
}

\author{
Author: ANACLETO RANULFO DOS SANTOS \\ Adviser: Prof. Dr. FRANCISCO ANTONIO MONTEIRO
}

\section{SUMMARY}

Two experiments were carried out in greenhouse conditions with Brachiaria decumbens Stapf. cv. Basilisk. Plants were grown in nutrient solution, using ground quartz as substrate. The first experiment was conducted from December 1995 to Febuary 1996, and eight rates of $N$ were evaluated $(0 ; 14$; $42 ; 126 ; 210 ; 294 ; 378$ and $462 \mathrm{mg} \mathrm{L}^{-1}$ ). In the second experiment plants were grown from October to December of 1996 and eight rates of sulfur were used $\left(0 ; 2 ; 4 ; 16 ; 32 ; 48 ; 64\right.$ and $\left.80 \mathrm{mg} \mathrm{L}^{-1}\right)$. The objective of this study was to evaluate the effects of nitrogen and sulfur on dry matter yield, tiller number. nitrate reductase activity, chlorophyll concentration, accumulation and concentration of each element in the plant components, and to establish parameters to determine the critical level of each nutrient. In each experiment a complete randomized block design was used, with four replications. In the first experiment, plants were first harvested 39 days after transplanting the seedlings to the pots and the second harvest was done 31 days after the first one. In the second experiment, plants were harvested 40 days after transplantig the seedlings to the pots, and again 30 days after the first harvest. Plants were harvested and separated into non-expanded leaves, young leaf blades, old leaf 
blades and stems+sheaths. After the second harvest roots were also collected.

The results of the first experiment showed significant responses of Brachiaria decumbens to nitrogen rates on dry matter yield of plant tops and roots, tiller number, nitrate reductase activity and chlorophyll concentration. The results showed that nitrogen concentration was lower in stems+sheaths than in any other plant top part. Young leaf blades should be sampled to for nitrogen diagnosis in Brachiaria decumbens and the critical level of nitrogen in this plant part is in the range of 14.5 the $22 \mathrm{~g} \mathrm{~N} \mathrm{~kg}^{-1}$ on dry matter.

The results of the second experiment showed significant effects of the sulfur rates on dry matter yield of Brachiaria decumbens. There was no significant effects of sulfur on the tiller number in the first growth, but such effect was observed in the second growth. Both nitrate reductase activity and chlorophyll concentration significantly changed with sulfur rates. The sulfur concentration was lower in stems+sheaths and in the young leaf blades in the higher rates of sulfur, in the first. In the second growth the highest sulfur concentration occured in the old leaf blades, with except for the highest sulfur rates. Sulfur accumulation was lower in the non-expanded leaves and higher in the stems+sheaths in the two growth periods. Young leaf blades are recommended for sulfur diagnosis in Brachiaria decumbens, and the critical level of sulfir in this plant part is between 0.81 the $1.00 \mathrm{~g} \mathrm{~S} \mathrm{~kg}^{-1}$ of dry matter. 


\section{INTRODUÇÃO}

O modelo de desenvolvimento da pecuária brasileira é considerado pouco eficiente. Entre os muitos fatores de interferência constata-se o desequilíbrio no sistema produtivo, uma vez que a aplicação da ação tecnológica vem sendo mais intensiva no melhoramento genético animal do que na obtenção e no estabelecimento de forrageiras mais produtivas. Neste contexto, deve-se considerar com mais ênfase a importância econômica do fornecimento de forragem através das pastagens, pois estas constituem a base dos sistemas de produção dos rebanhos.

O predomínio de pastagens nativas que apresentam baixo rendimento e a implantação de forrageiras em solos com baixa fertilidade, com altas concentrações de alumínio e sujeitos a veranicos, também são fatores que limitam a disponibilidade e a qualidade da forragem. Plantas forrageiras vêm sendo pesquisadas com mais intensidade nos últimos anos, na busca de se conseguir material genético de maior produtividade e mais adaptado às condições edafoclimáticas das regiões brasileiras.

O capim-braquiária (Brachiaria decumbens Stapf.), bastante difundido nas regiões brasileiras (principalmente nas áreas de cerrado, com aproximadamente 206 milhões de hectares) apresenta boas condições de adaptabilidade edafo-climática. Apesar de sua destacada importância, essa forrageira vem apresentando queda de produção após ciclos de pastejo devido a degradação das pastagens. Têm sido observados problemas de deficiências minerais em cultivos de capim-braquiária, sendo que, informações relativas à 
composição mineral, mostram que essa forrageira apresenta respostas diferenciadas quando submetida a variações na disponibilidade de nitrogênio e de enxofre no sistema de produção.

O lançamento de gramíneas forrageiras como tentativa de aumentar a produtividade e melhorar o valor nutritivo e alimentício das pastagens não tem atingido a expectativa do mercado, provavelmente pela escassez de resultados referentes às exigências nutricionais desses capins e o inadequado manejo aplicado.

O estudo de processos metabólicos na forrageira envolvendo o nitrogênio e o enxofre permitirá melhor conhecimento da potencialidade produtiva das gramíneas. As informações geradas podem contribuir positivamente no estabelecimento, no aumento da produtividade e no controle da degradação das pastagens.

Os objetivos deste estudo foram avaliar respostas da Brachiaria decumbens Stapf. cv. Basilisk, cultivada em solução nutritiva, a doses de nitrogênio e de enxofre quanto à produção de matéria seca, ao número de perfilhos, à atividade da enzima redutase do nitrato, ao teor de clorofila, o nivel crítico, à concentração e o acúmulo desses nutrientes nos componentes da planta. 


\section{REVISÃO DE LITERATURA}

\subsection{Brachiaria decumbens Stapf.}

A introdução de capins do trópico africano em áreas tropicais da América tem sido de grande importância, por apresentar uma melhor adaptação às condições de baixa fertilidade do solo e das variações climáticas com médias e altas precipitações concentradas no verão. No Brasil, as primeiras introduções basearam-se nas espécies Melinis minutiflora Pal de Beauv, Hyparrhenia rufa (Ness) Stapf. e Panicum maximum Jacq., e posteriormente as espécies dos gêneros Digitaria, Setaria, Cynodon, destacando-se as do gênero Brachiaria principalmente pela grande expansão das áreas de pastagens na região dos cerrados (Rocha, 1991).

Tendo como principal centro de origem a África tropical e de ocorrência natural as savanas africanas, a Brachiaria decumbens Stapf. é uma das gramineas que mais tem sido utilizada para formação de pastagens no mundo. No Brasil há dois cultivares de Brachiaria decumbens. O primeiro, conhecido como cultivar IPEAN, foi introduzido pelo Instituto de Pesquisa Agropecuária do Norte - IPEAN no Belém-PA em 1952, é de crescimento mais decumbente, com raizes nos nós e folhas muito pilosas. O segundo. proveniente da Austrália, porém de origem também africana, teve seu desenvolvimento inicial no Estado de São Paulo, é mais robusto, de crescimento sub-erecto e com folhas menos pilosas. É conhecido como cultivar 
Basilisk ou braquiária Australiana (Alcântara, 1987).

Cultivada em todas as regiões do pais, essa forrageira destaca-se nas grandes extensões de áreas na região Central. Estima-se que pastagens de braquiária ocupem mais de 40 milhões de hectares no Brasil e as espécies Brachiaria decumbens e Brachiaria brizantha cv. Marandu representam mais de 85 \% dessa área (Valle \& Miles, 1994). Santos Filho (1990) citou a acentuada atividade de produção de sementes de Brachiaria no pais a partir da década de 70, passando de importador mundial para o principal exportador, e estimou que as espécies do gênero Brachiaria respondiam por $70 \%$ da quantidade de sementes de forrageiras comercializadas anualmente no pais.

Os capins do gênero Brachiaria vem ocupando de forma crescente, as áreas de pastagens nativas, que geralmente são de baixo rendimento de forragem e de proteina bruta, sendo considerado o capim mais plantado no pais e utilizado na cria, recria e engorda dos animais. De modo geral, as braquiárias são espécies que têm elevado potencial de produção de forragem em solos férteis ou corrigidos com adubações (Soares Filho, 1994).

De acordo com Valle \& Miles (1994), os estudos de melhoramento com os capins do gênero Brachiaria são recentes e envolvem hibridação interespecifica por não existirem ainda plantas sexuais compativeis nas espécies de importância agronômica. Citaram também que já foram iniciados os primeiros cruzamentos entre Brachiaria ruziziensis, sexual e artificialmente tetraploidizada, com Brachiaria decumbens e Brachiaria brizantha, apomiticas tetraploides naturais. Além disso, consideraram grandes as perspectivas de obtenção de novos cultivares por via de seleção direta ou melhoramento genético.

Rocha (1985) relatou que em levantamento realizado pelo Instituto Agronômico e pelo Instituto de Zootecnia, a Brachiaria decumbens ocorria em $92 \%$ dos municipios do Estado de São Paulo. 
A disseminação da Brachiaria decumbens, deu-se de maneira acentuada devido à boa produção e germinação de sementes, alta agressividade na competição com vegetação nativa e elevada disseminação pela semeadura natural. Além disso, constata-se ser mais tolerante à seca que os capins angola (Brachiaria multica), tangola (híbrido de Tannagrass e angola), Brachiaria humidicola e Brachiaria ruziziensis. O capim-braquiária, muito usado nos cerrados, foi o primeiro capim a ser plantado em larga escala, embora se desenvolva melhor em regiões tropicais úmidas onde as estações secas não duram mais que quatro meses. As pastagens formadas com essa forrageira frequentemente apresentam redução gradativa de produtividade após estabelecimento (Carvalho et al., 1991). Segundo Myers \& Robbins (1991), a deficiência de nitrogênio é o principal fator de degradação das pastagens cultivadas.

Soares Filho et al. (1992) citaram que a maioria das pastagens com capim-braquiária no Estado de São Paulo encontram-se em estado de degradação e consideraram, dentre as causas mais comuns para esse declínio, o esgotamento da fertilidade do solo e o manejo inadequado das gramíneas.

Karia \& Andrade (1996) relataram que, entre os acessos avaliados pelo Centro de Pesquisa Agropecuária dos Cerrados (CPAC), Centro Internacional de Agricultura Tropical (CIAT) e o Centro Nacional de Recursos Genéticos (CENARGEN), o gênero Brachiaria representou $84 \%$ das introduções efetuadas de 1986 a 1989, destacando-se entre as gramíneas por sua adaptação aos solos da região do Cerrado.

No ecossistema de pastagem os componentes de produção, como o solo com todos os seus atributos físicos, químicos e biológicos, a gramínea forrageira, os macro e microrganismos animais, os fatores externos e o manejo aplicado devem interagir para que haja um processo dinâmico com maximização ou mesmo manutenção da eficiência na produtividade da 
forrageira e dos animais que se beneficiam dessa pastagem. A não observância desses princípios é sem dúvida o principal responsável pelos fracassos na condução de sistemas de produção duradouros e produtivos na atividade pecuária (Nascimento Jr. et al., 1994).

Considerando aspectos que influenciam uma pastagem estabelecida, a densidade de plantas, que é resultado da relação entre o aparecimento de novas plantas e da mortalidade das existentes, é alterada pelas condições climáticas adversas ou mesmo devido a processos competitivos. $O$ arranjamento e o espaçamento das plantas devem receber o manejo adequado, como também a ação dos sucessivos pastejos que estimulam a planta a um novo ajuste morfológico para se estabilizarem no sistema.

\subsection{Nitrogênio}

O nitrogênio, apesar de abundante na atmosfera na forma de $N_{2}$, está presente em pequenas quantidades na maioria dos solos. Este elemento é um constituinte de numerosos compostos orgânicos, entre os quais aminoaçúcares, aminas, amidas, vitaminas, pigmentos (Malavolta, 1979), aminoácidos, proteínas, ácidos nucléicos e molécula de clorofila (Mengel \& Kirkby, 1987). De acordo com Taiz \& Zeiger (1991) o nitrogênio é o elemento chave em muitos compostos presentes nas células das plantas, destacando sua importância pelo fato de que apenas o oxigênio, o carbono e o hidrogênio são mais abundantes nas células das plantas superiores.

A matéria seca das plantas contém cerca de 2 a $4 \%$ de nitrogênio. $\mathrm{Na}$ planta, o nitrogênio pode ser fracionado em $\mathrm{N}$-inorgânico $\left(\mathrm{NO}_{3}{ }^{-}\right.$e $\left.\mathrm{NH}_{4}{ }^{+}\right), \mathrm{N}$ protéico e $\mathrm{N}$-alfa amino solúvel que é a fração mais variável devido aos 
distúrbios nutricionais (Silveira, 1980). A diminuição da intensidade luminosa e da temperatura pode causar aumento da quantidade de $\mathrm{N}$-alfa amino nos tecidos e provocar limitação na produção de matéria seca da planta. Em condições de deficiência ou quando em excesso de nitrogênio as formas solúveis começam a acumular-se nos tecidos (Novoa \& Loomis, 1981)

O nitrogênio, uma vez absorvido pela planta, é reduzido à forma amoniacal e combinado nas cadeias orgânicas da planta, formando ácido glutâmico que constituirá os aminoácidos. Esses são básicos na formação de proteinas, que participam nos processos metabólicos das plantas, tendo um papel mais funcional que estrutural.

As formas amoniacal e nitrica podem ser absorvidas e metabolizadas pelas plantas (Tisdale et al.,1985). O devido conhecimento da proporção de amônio e nitrato no sistema de cultivo é importante fator no que se refere à aquisição de nitrogênio pelas plantas (Mills et al.,1976).

Mengel \& Kirkby (1987) relataram que o nitrato é frequentemente a fonte preferida pelas culturas porém, depende da espécie da planta e de fatores ambientais. Os mesmos autores enfatizaram que a absorção do nitrato é um processo ativo, que o mesmo move-se contra um gradiente eletroquímico e é dependente da concentração de nitrato no meio externo. Segundo DeaneDrummond, (1990), essa absorção é regulada pela absorção de cátions como $\mathrm{K}^{+}, \mathrm{Ca}^{++}, \mathrm{Mg}^{++}$ou pela excreção de outros ânions $\left(\mathrm{OH}^{-}\right.$ou $\left.\mathrm{HCO}_{3}{ }^{-}\right)$para manter a eletronegatividade dentro da planta.

Marschner (1995) citou que a acumulação do nitrato no vacúolo é fundamental para o balanço de cátions e ânions assim como para o processo de osmoregulação. Para tanto, torna-se necessária a redução do nitrato a amônia para que haja incorporação do nitrogênio em estruturas orgânicas nas plantas.

A absorção do amônio pode induzir aumento na absorção de forma 
aniônica. Este amônio pode promover efeito competitivo com os cátions básicos, de maneira tal que a concentração destes cátions venha a ser menor em plantas dependentes de nitrogênio amoniacal do que nítrico (Adams, 1981). Grande parte do amônio absorvido pode ser incorporado em compostos orgânicos nas raizes e ser armazenado nos vacúolos das células das raízes. Em condições normais o amônio não é acumulado, porém por ser tóxico em concentrações relativamente baixas, pode causar alterações metabólicas. Essa condição pode ocorrer se houver absorção excessiva ou a falta de esqueletos carbônicos para sua incorporação (Fernandes \& Rossielo, 1986).

\subsection{Nitrogênio no capim-braquiária}

A adubação nitrogenada tem sido muito estudada nos sistemas de pastagens, principalmente pela comprovada importância que este nutriente exerce no desenvolvimento das forrageiras. De acordo com Vicente-Chandler (1973), as gramíneas tropicais podem responder a doses de nitrogênio de até $1800 \mathrm{~kg} \mathrm{ha}^{-1}$ ano $^{-1}$, sendo que estas respostas ocorrem de forma diferenciada, dependendo da espécie.

Werner et al. (1967), estudando o capim-colonião, observaram que, à exceção da adubação fosfatada, a falta da adubação nitrogenada foi a que mais influenciou no crescimento inicial dessa forrageira, limitando a produção de matéria seca e o número de perfilhos.

Avaliando o comportamento da Brachiaria ruziziensis em Porto Rico, Vicente-Chandler et al. (1972) encontraram respostas até $400 \mathrm{~kg}$ de $\mathrm{N} \mathrm{ha}^{-1}$ para intervalos de corte de 30 e 45 dias e até $200 \mathrm{~kg}_{\text {de N ha }}{ }^{-1}$ para 60 e 90 dias.

Trabalho desenvolvido pelo CIAT (1978) mostrou que, no primeiro ano o capim-braquiária 606 respondeu positivamente até a dose de $400 \mathrm{~kg}$ de 
$\mathrm{N}$ ha ${ }^{-1}$, enquanto que o colonião precisou de $200 \mathrm{~kg}_{\text {de }} \mathrm{N} \mathrm{ha}^{-1}$ para atingir seu máximo rendimento de matéria seca. No segundo ano, essas forrageiras apresentaram respostas lineares até $400 \mathrm{~kg}$ de $\mathrm{N} \mathrm{ha}^{-1} \mathrm{ano}^{-1}$.

Estudando níveis de nitrogênio até a dose de $1400 \mathrm{~kg} \mathrm{ha}^{-1} \mathrm{em}$ Brachiaria decumbens, Harding \& Grof (1978) consideraram o nivel de $365 \mathrm{~kg}$ de $\mathrm{N}$ ha ${ }^{-1}$ ano $^{-1}$ como ótimo, em termos de produção de matéria seca e aproveitamento de nitrogênio.

Sanzonowicz (1986) relatou que em pastagens estabelecidas há mais de cinco anos, o nitrogênio foi o principal nutriente que limitou 0 rendimento em matéria seca das pastagens de Brachiaria ruziziensis e Brachiaria decumbens. Segundo Boin (1986), a produção de matéria seca de gramíneas em resposta à adubação nitrogenada, dentro de limites, apresentou comportamento normalmente linear, variando fundamentalmente com a frequência de cortes e com as condições de solo e clima.

Resposta diferencial na produção de matéria seca foi obtida por Pereira (1986), na avaliação de quatro braquiárias submetidas a cinco doses de nitrogênio em solos de cerrrado. A Brachiaria decumbens e Brachiaria ruziziensis tiveram as maiores produções de matéria seca em todas as doses de nitrogênio, exceto na ausência de adubação nitrogenada em que a Brachiaria decumbens cv.IPEAN foi a mais produtiva.

Alvim et al. (1990) constataram que todos os acessos de Brachiaria estudados em Latossolo Vermelho-Amarelo responderam aos níveis de nitrogênio aplicado até $150 \mathrm{~kg} \mathrm{ha}^{-1}$. $\mathrm{Na}$ dosagem de $75 \mathrm{~kg}$ de $\mathrm{N} \mathrm{ha}^{-1}$, a produção de matéria seca dos acessos de Brachiaria decumbens e Brachiaria brizantha não apresentaram diferenças. Entretanto, na ausência deste elemento os acessos de Brachiaria decumbens foram os mais produtivos. Respostas marcantes na produção de matéria seca da Brachiaria decumbens submetida até a dose de $400 \mathrm{~kg}$ de $\mathrm{N} \mathrm{ha}^{-1} \mathrm{ano}^{-1}$, foram observadas por 
Carvalho et al. (1991).

Hoffmann (1992) obteve a máxima produção da Brachiaria decumbens com o emprego da dose de $437 \mathrm{mg}$ de $\mathrm{N} \mathrm{kg}^{-1}$ de solo. Santos et al. (1995) observaram que o capim-vencedor (Panicum maximum) submetido a doses de nitrogênio atingiu o rendimento máximo de matéria seca da parte aérea com a dose de $362 \mathrm{mg}$ de $\mathrm{N} \mathrm{L}^{-1}$ de solução nutritiva. Em estudo com doses de nitrogênio, Almeida \& Monteiro (1995) citaram que as máximas respostas do capim-coastcross 1 (Cynodon dactylon) na produção de matéria seca da parte aérea ocorreriam mediante o emprego de doses superiores a 280 mg de $N^{-1}$ de solução nutritiva.

A concentração de proteína bruta é um dos parâmetros utilizados para avaliação das plantas forrageiras. Milford \& Minson (1965) citaram que há redução do consumo de matéria seca pelos animais quando o teor de proteína bruta estiver abaixo de $7 \%$ nas forrageiras tropicais.

Objetivando avaliar o valor nutritivo de espécies forrageiras tropicais, Bredon \& Horrell (1962) encontraram variação no teor de proteína bruta de 5,2 a $7,5 \%$ na Brachiaria decumbens e de 4,2 a $7,5 \%$ na Brachiaria brizantha. Monteiro \& Werner (1977) avaliaram o comportamento do capim-colonião cultivado em vasos com Podzólico Vermelho-Amarelo, variação Laras, e verificaram importância destacada do fósforo e do nitrogênio no estabelecimento da forrageira. com aumento de produção de matéria seca e de proteína total em relação ao tratamento testemunha.

Oliveira (1980), estudando a Brachiaria decumbens, observou que o teor de proteína foi constante a partir do $42^{\circ}$ dia de crescimento e, de maneira geral, acompanhou o rendimento da cultura. Nesse estudo, o teor de proteína bruta na matéria seca a $105{ }^{\circ} \mathrm{C}$ variou de $7,90 \%$ a $2,64 \%$ no período de 21 a 126 dias de crescimento.

Botrel et al. (1990) observaram que o teor de proteína bruta na 
matéria seca aumentou em todos os acessos de Brachiaria em função do nitrogênio aplicado tanto no período da seca como no período das águas. Estes autores sugeriram que, em se mantendo o suprimento adequado de nitrogênio, as gramineas do gênero Brachiaria podem constituir alternativas para alimentar vacas em lactação com potencial médio de produção de leite.

Baixas concentrações de nitrogênio na parte aérea da Brachiaria decumbens foram observadas por Fernandes et al. (1985), tendo valores variando de 0,78 a 0,90\%, considerando o nível zero e a aplicação de $40 \mathrm{~kg}$ de $\mathrm{N}$ ha ${ }^{-1}$, respectivamente. Na Colombia, Salinas \& Gualdrón (1988) também observaram teores relativamente baixos de $\mathrm{N}$-total na parte aérea de três espécies de Brachiaria (B. decumbens, B. brizantha, B. humidicola), sendo que esses teores decresceram rapidamente com o aumento da idade das plantas na rebrota. No capim-braquiária o teor de nitrogênio diminuiu na estação chuvosa (de 2,04\% aos 28 dias para $1,10 \%$ aos 84 dias) enquanto na estação seca esta redução foi de 1,5 \% para 0,82 \%, para o mesmo período.

Carvalho et al. (1991) constataram em um Latossolo VermelhoAmarelo álico, que a concentração de nitrogênio na parte aérea da Brachiaria decumbens aumentou linearmente com aplicação desse nutriente até $400 \mathrm{~kg}$ $\mathrm{ha}^{-1}$. Para esses autores, as concentrações de nitrogênio na parte aérea dessa forrageira foram consideradas baixas com valores de 1,7 a 2,1 \%, e quando não se aplicou o nitrogênio as concentrações deste nutriente variaram de 0,8 a $1,4 \%$. Também verificaram que nos tratamentos com elevadas produções de matéria seca, obtidas com altos niveis de adubação, houve uma redução nas concentrações de nitrogênio na forragem, caracterizando-se um efeito de diluição.

Faquin et al. (1995b) estudaram a omissão de nutrientes nos capins Brachiaria brizantha e Andropogon gayanus e observaram que os tratamentos que mais limitaram o crescimento das plantas foram a omissão de $N, P$ e K. 
Este fato pode ser explicado pelo efeito de concentração dos elementos nos tecidos, devido à baixa produção de matéria seca nestes tratamentos.

\subsection{Enxofre}

Este nutriente é componente dos aminoácidos cisteína, metionina e cistina, os quais podem conter cerca de $90 \%$ do total de enxofre na planta. É componente da acetil CoA e produtos secundários na planta, está envolvido na formação da clorofila e na síntese de vitaminas como tiamina e biotina (Malavolta et al., 1974). Além disso, faz parte da ferredoxina, molécula transferidora de elétrons envolvida na fotossíntese, na fixação de nitrogênio atmosférico e na redução de compostos oxidados tal como o nitrato (Malavolta et al., 1974; Smith \& Siregar, 1983; Mengel \& Kirkby, 1987).

Malavolta (1980) mencionou que o enxofre é absorvido ativamente pelas raizes e preferencialmente na forma oxidada de sulfato $\left(\mathrm{S}_{-} \mathrm{SO}_{4}{ }^{-2}\right)$ e na forma orgânica como aminoácidos (cisteína, metionina, cistina), enquanto o S$\mathrm{SO}_{2}$, existente no ar, pode ser absorvido pelas folhas de forma pouco eficiente. $\mathrm{Na}$ planta, $\circ \mathrm{S}_{-} \mathrm{SO}_{4}{ }^{-2}$ é transportado predominantemente na direção acrópeta. Contudo, a capacidade da planta para deslocar o enxofre na direção basípeta é reduzida. O mesmo autor relatou que a função metabólica mais importante do enxofre é a sua formação no radical sulfidrilo $(-\mathrm{SH})$, que constitui o grupo ativo de muitas enzimas envolvidas no anabolismo e no catabolismo dos carboidratos, gorduras e proteinas.

$\mathrm{Na}$ atmosfera a concentração de $\mathrm{SO}_{2}$ está na faixa de 10 a $40 \mu \mathrm{g} \mathrm{m}^{-3}$, e quando em alta concentração $\circ \mathrm{SO}_{2}$ é considerado tóxico para as plantas. $\mathrm{O}$ nivel considerado crítico para plantas anuais é de $120 \mu \mathrm{g} \mathrm{m}^{-3}$ e para as perenes, destacando-se os ecossistemas florestais, em torno de $60 \mu \mathrm{g} \mathrm{m}^{-3}$. Em 
plantas, quando submetidas ao efeito tóxico do $\mathrm{SO}_{2}$ por período prolongado, o gás $\mathrm{SO}_{2}$ e os ânions $\mathrm{HSO}_{3}{ }^{-}$e $\mathrm{SO}_{3}{ }^{2-}$ podem acumular e limitar a fotofosforilação, além de provocar distúrbios na membrana do cloropasto (Mengel \& Kirkby, 1987). $\mathrm{O} \mathrm{SO}_{2}$ da atmosfera pode ser dissolvido nas gotas de água das chuvas e desta forma penetrar no solo, onde é oxidado $\mathrm{a} \mathrm{SO}_{4}{ }^{2-}$.

Marschner (1995) relatou que a cisteína é o primeiro produto estável da redução do sulfato assimilado e atua como precursor para sintese de todos os outros compostos orgânicos contendo enxofre reduzido, como também para formação de produtos biosintéticos, como o etileno. Altas concentrações de cisteina podem inibir a ação da enzima adenosina 5-fosfosulfato (APS) sulfotransferase que atua no processo de redução do sulfato. $O$ fornecimento de amônio em relação ao nitrato favorece o aumento da atividade dessa enzima.

Em plantas deficientes em enxofre, a inibição da sintese de proteinas está correlacionada à acumulação de nitrogênio orgânico solúvel e de nitrato. Nessas plantas, tanto decresce a quantidade de proteinas como o conteúdo de enxofre nessas proteinas, indicando proteinas com baixa proporção de metionina e cisteína, porém com alta proporção de outros aminoácidos como arginina e asparagina que são sintetizados (Marschner. 1995).

Nas plantas superiores, as enzimas assimilatórias do sulfato reduzido estão localizadas nos cloroplastos, porém podem ser encontradas em menor quantidade nos plastídeos das raízes. Em geral, a redução do sulfato é muitas vezes maior nas folhas verdes do que nas raizes.

Nas plantas das regiões tropicais a deficiência de enxofre vem sendo constatada frequentemente, tornando-se um sério problema para a maioria das culturas, e particularmente para as plantas forrageiras. O baixo teor de enxofre no perfil do solo é dependente da sua pedogênese e das práticas culturais 
aplicadas no sistema solo-planta. De acordo com Sanches (1981), a maior parte do enxofre contido nos solos tropicais não adubados está na forma orgânica.

McClung et al. (1959) relataram que solos do Planalto Central brasileiro apresentavam problemas de baixo teor de enxofre, sendo que 0 crescimento das plantas nos tratamentos com omissão deste elemento foi de apenas 4 a $30 \%$ do obtido no tratamento com enxofre. Esses autores verificaram que, em condições de queimada simulada, $75 \%$ do enxofre contido na matéria seca das gramíneas perdeu-se por volatilização e que o enxofre remanescente nas cinzas era facilmente passivel de ser lixiviado.

Nos últimos anos a maior utilização de adubos concentrados como a uréia, o superfosfato triplo e o cloreto de potássio, reduziu significativamente a adição do enxofre nas áreas de cultivo, com efeitos mais agravantes em solos de textura mais arenosa, com baixos teores de matéria orgânica, com alta incidência pluviométrica favorecendo a lixiviação do sulfato e nos submetidos a queimadas periódicas (Malavolta et al., 1974; Vitti \& Novais, 1986).

Outros fatores também merecem destaque quanto à redução da disponibilidade de enxofre para as plantas. Pode-se ressaltar o desenvolvimento de agricultura intensiva com elevado nivel de tecnificação, variedades melhoradas com maior exigência nutricional, ocasionando maior extração de enxofre do sistema de produção, perdas de sulfato por lixiviação após calagem e adubação fosfatada. Estudo com plantas de algodoeiro demonstraram que o conteúdo de açúcar nas folhas diminuiu marcadamente com a deficiência de enxofre na planta, indicando que a concentração de $\mathrm{CO}_{2}$ é reduzida nesta condição. Também, a síntese de proteínas é reduzida e o suprimento de carboidratos necessários para as funções metabólicas (assimilação de nitrogênio e enxofre) pode ser muito reduzido (Ergle \& Eaton, 1951). 


\subsection{Enxofre no capim-braquiária}

Mikkelsen \& Camberato (1995) citaram que forrageiras implantadas em solo com baixo teor de enxofre geralmente têm menor conteúdo em proteínas e alta concentração de nitrato, o que afeta 0 desempenho e 0 desenvolvimento animal. Segundo Shirley \& Mariante (1976) o teor de enxofre na faixa de 0,1 a $0,2 \%$ na forrageira é recomendado para dietas de bovinos e ovinos. Aceitando-se o teor de $0,1 \%$, apenas $30 \%$ dos capins e $52 \%$ das leguminosas no pasto se situaram dentro ou acima desse nível no Estado de São Paulo, em levantamento realizado por Gallo et al. (1974). Nesse estudo, os autores encontraram teor de enxofre da ordem de $0,14 \%$ na matéria seca da parte aérea do capim Brachiaria decumbens.

Werner et al. (1967), estudando respostas do capim-colonião em um Latossolo Vermelho-Escuro fase arenosa, observaram significativo aumento na produção de matéria seca quando se empregou $40 \mathrm{~kg}$ de $\mathrm{S} \mathrm{ha}^{-1}$ numa adubação completa.

Estudo desenvolvido pelo CIAT (1978) na Colômbia demonstrou que, entre as gramíneas avaliadas quanto à influencia do enxofre, a Brachiaria decumbens foi a mais exigente, respondendo a aplicações de até $20 \mathrm{~kg}$ de $\mathrm{S}$ $\mathrm{ha}^{-1}$, enquanto a Brachiaria humidicola foi a menos exigente.

Casagrande \& Souza (1982), estudando resposta de gramíneas forrageiras a quatro doses de enxofre $\left(0,15,30,60 \mathrm{~kg} \mathrm{ha}^{-1}\right)$ em três solos (Areia Quartzosa, Latossolo Vermelho Escuro eutrófico fase cerradão, Latossolo Vermelho Escuro distrófico fase cerrado), após três cortes, observaram que as forrageiras responderam significativamente até $30 \mathrm{~kg}$ de $S$ $\mathrm{ha}^{-1}$, sendo Brachiaria decumbens e Melinis minutiflora cv. Cabelo-de-Negro as que mais responderam em aumento da produção de matéria seca.

Werner \& Monteiro (1988) relataram que as maiores respostas de 
forrageiras à adubação com enxofre têm ocorrido em solos arenosos com baixos teores de matéria orgânica, e que pastagens exclusivas de gramíneas não adubadas com nitrogênio e fósforo mostram pouca ou nenhuma resposta ao enxofre. Esses autores citaram que a concentração deste nutriente na planta acima daquela requerida para a sintese de proteínas resulta em acumulação do enxofre no tecido vegetal, especialmente na forma de sulfato.

Trabalhando com Latossolo Vermelho-Escuro, Ferrari Neto (1991) verificou que entre outros nutrientes o enxofre apresentou niveis de deficiências severas para o desenvolvimento do capim-braquiária e do colonião, que são as forrageiras mais usadas na região do Arenito Caiuá no Paraná. Em condições de omissão de enxofre, essas forrageiras apresentaram redução de 30 a 41\% na produção de matéria seca da parte aérea, no total de dois cortes.

A Brachiaria decumbens alcançou o máximo rendimento da parte aérea com adição de $76 \mathrm{mg}$ de $S \mathrm{~kg}^{-1}$ de solo (Hoffmann, 1992). A aplicação de doses de enxofre até a dose de $160 \mathrm{mg} \mathrm{kg}^{-1}$ de solo resultou em aumento no teor de enxofre na parte aérea no primeiro e segundo cortes de 0,06 a 0,34 $\%$. Entretanto, com $\circ$ incremento de doses de nitrogênio, o teor de enxofre diminuiu de 0,34 a $0,22 \%$ no primeiro corte e de 0,55 a $0,28 \%$ no segundo corte.

Estudando Brachiaria decumbens cv. Basilisk e Brachiaria brizantha cv. Marandu crescidas em Latossolo Vermelho-Escuro, Ferrari Júnior et al. (1994) verificaram que os teores de enxofre apresentaram valores médios de $0,12 \%$ e não diferiram entre as gramíneas. Os teores de proteina bruta nos capins estiveram acima de $7 \%$ quando cortados até por volta de 64 dias para Brachiaria decumbens e 67 dias para Brachiaria brizantha.

Respostas significativas na produção de matéria seca da braquiária decumbens cultivada em vasos com Latossolo Vermelho-Escuro devido a aplicação de doses de enxofre, foram observadas por Faquin et al. (1995b). 
Avaliando a Brachiaria brizantha submetida a doses de enxofre em solução nutritiva, Monteiro \& Ono (1995) constataram efeitos significativos da aplicação deste nutriente na produção de matéria seca da parte aérea e das raízes da planta.

Marques et al. (1995) relataram que a omissão de enxofre não afetou o rendimento total de matéria seca da parte aérea da Brachiaria brizantha e Andropogon gayanus cultivados em Cambissolo álico. Monteiro et al. (1995) verificaram reduções significativas na produção de matéria seca e na altura das plantas no tratamento em que se omitiu enxofre, quando comparado ao tratamento completo.

Faquin et al. (1995b) observaram que a matéria seca do segundo corte da Brachiaria brizantha apresentou baixo teor de enxofre $(0,03 \%)$ no tratamento com omissão desse nutriente, quando comparado ao tratamento completo $(0,08 \%)$. Estes autores não constataram diferença significativa entre esses tratamentos no capim-andropogon (0,06 e 0,05\% respectivamente).

Em estudo com Brachiaria decumbens, Faquin et al. (1995a) observaram que as máximas produções de matéria seca no primeiro e no segundo cortes, foram obtidas nas doses de enxofre de 65 e $100 \mathrm{mg} \mathrm{kg}^{-1}$ de solo, respectivamente. Entretanto, 90\% destas produções nos dois cortes

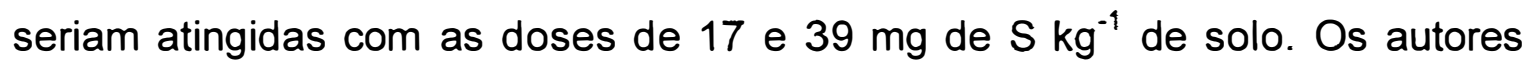
ressaltaram que os maiores incrementos na produção ocorreram com as doses mais baixas de enxofre.

\subsection{Relação nitrogênio:enxofre}

A importância do equilíbrio entre a quantidade de nitrogênio $e$ enxofre no solo e na planta é refletida no crescimento e no estado nutricional 
do vegetal. A adição de doses mais elevadas de um desses elementos no sistema de produção pode induzir à menor disponibilidade de um outro elemento para a planta.

O nitrogênio e o enxofre são componentes da molécula dos aminoácidos. Em condições de deficiência desses elementos pode ocorrer menor teor de aminoácidos, diminuição na síntese de proteínas e aumento na relação $\mathrm{N}$ solúvel: $\mathrm{N}$ protéico.

O suprimento de enxofre para atender as necessidades das forrageiras tem sido avaliado através da concentração de S-total, S-sulfato e relação $\mathrm{N}: \mathrm{S}$ no tecido da planta. A relação $\mathrm{N}: \mathrm{S}$ tem sido preferencialmente utilizada para avaliar o estado nutricional das plantas forrageiras, assim como 0 máximo rendimento em matéria seca, uma vez que essa relação mantém-se mais constante nos diferentes estádios de desenvolvimento da planta (Spencer et al., 1977; Smith \& Siregar, 1983).

Segundo Tisdale (1977) a maioria das plantas tem crescimento adequado quando a relação $\mathrm{N}: \mathrm{S}$ da forragem está entre 14:1 e 16:1. Esse autor sugeriu que, quando os teores de $S$ na forragem estiverem ao redor de 0,20 a $0,25 \%$ ou mais e a proporção $\mathrm{N}: \mathrm{S}$ estiver entre $10: 1$ e 12:1, serão considerados adequados aos animais e não haverá melhoria no desempenho animal com suplementação de enxofre.

$\mathrm{Na}$ parte aérea de plantas da espécie Brassica napus L., foi observada redução na produção de matéria seca e na relação $\mathrm{N}: \mathrm{S}$ quando doses elevadas de enxofre foram aplicadas na ausência de nitrogênio (Jansen \& Bettany, 1984).

Monteiro \& Carriel (1987) citaram que a aplicação de $40 \mathrm{~kg}$ de $S \mathrm{ha}^{-1}$ num solo Podzólico resultou numa relação N:S de 13,7:1 e numa porcentagem aproximada de $0,08 \%$ de enxofre no capim-colonião, por ocasião do segundo corte. Werner \& Monteiro (1988) relataram que as pastagens com deficiência 
em nitrogênio apresentam baixas respostas ao enxofre. Consequentemente, alta disponibilidade de nitrogênio requer maior aplicação de enxofre, uma vez que este nutriente é importante no metabolismo do nitrogênio e na síntese de proteína.

\subsection{Perfilhamento do capim-braquiária}

Langer (1963), em estudo de revisão, citou que a capacidade de perfilhamento das gramíneas forrageiras depende de muitos fatores, entre os quais destacam-se as características genéticas de cada espécie e o seu estado nutricional. Enfatizou que o nitrogênio é o nutriente mais importante para o perfilhamento de gramíneas estabelecidas, visto que, em condições de deficiência deste nutriente, o número de perfilhos na planta é significativamente reduzido.

Nabinger (1997) citou que genótipos com alta taxa de surgimento de folhas, apresentam alto potencial de perfilhamento e, assim, determinam uma pastagem com uma densidade de perfilhos mais elevada do que aquelas com baixa taxa de surgimento de folhas. Plantas mais espaçadas permitem maior incidência de luz na base de suas touceiras, estimulando aparecimento de perfilhos em maior número e por maior tempo do que para plantios adensados, que tendem a ser menos eretos por conta da menor competição por luz no início.

O número e o tamanho dos perfilhos, dentro de limites, podem compensar o efeito de densidade de plantas, sendo aspectos que influenciam a produtividade de uma pastagem (Langer, 1974). Nabinger (1997) relatou efeitos positivos do nitrogênio na taxa de aparecimento de perfilho. Contudo, altas disponibilidades desse elemento podem determinar uma menor densidade de 
perfilhos na pastagem devido ao mais rápido desenvolvimento do índice de área foliar e ao aumento na mortalidade. Langer (1974) citou que o perfilho caracteriza a unidade estrutural e produtiva das gramíneas forrageiras, e é classificado em aéreo e basal.

O aparecimento e o desenvolvimento de perfilhos estão associados à atividade meristemática. Nas gramíneas tropicais e considerando as diferenças entre genótipos, o perfilhamento relaciona-se positivamente com as altas temperaturas, maior intensidade luminosa e maior disponibilidade de água e nutrientes minerais (Langer, 1963). De acordo com a severidade do corte, estádio de crescimento e genótipo da planta, a remoção do ápice ou de todo o caule pode promover ou inibir o perfilhamento (Favoretto, 1993). De acordo com Nabinger (1997), o potencial de perfilhamento ou de ramificação de um genótipo é determinado pela sua velocidade de emissão de folhas pois a cada folha formada corresponde a geração de uma ou mais gemas axilares.

O nitrogênio é fundamental no crescimento de gramíneas, tendo influência no tamanho das folhas, no colmo e no desenvolvimento dos perfilhos (Werner, 1986). O momento da aplicação do adubo nitrogenado, a luminosidade e a disponibilidade de água no solo são fatores que influenciam no efeito do nitrogênio no perfilhamento da planta. Esse nutriente deve estar disponivel no periodo em que a planta estimula todos os sítios de crescimento para a reconstituição da parte aérea (Corsi, 1986). Gastal \& Nelson (1994) citaram que o nitrogênio influencia na taxa de elongação foliar em função do acúmulo deste nutriente na zona de alongamento da folha, mais especificamente na região de divisão celular. A deficiência de nitrogênio reduz ligeiramente a duração de vida das folhas, porém, a taxa de senescência aumenta devido ao pronunciado efeito do nitrogênio na taxa de aparecimento e no tamanho da folha (Mazzanti \& Lemaire 1994).

De acordo com Andrade (1987), condições favoráveis no início da 
estação de crescimento facilitam o desenvolvimento das gemas, o que define elevada densidade de perfilhos. Entretanto, com o aumento do índice de área foliar, ocorre maior competitividade por luz, reduzindo a densidade de perfilhos. Com o crescimento da forrageira tem-se verificado aumento no peso do perfilho, que depende das condições ambientais, influenciando a taxa de aparecimento de folhas e elongação do colmo, que são maiores com o estímulo ao florescimento (Langer, 1974; Corsi,1986).

Hoffmann (1992) avaliou o efeito de doses de nitrogênio até a dose de $500 \mathrm{mg} \mathrm{kg}^{-1}$ de solo em Brachiaria decumbens e observou que 0 perfilhamento, por ocasião do primeiro corte, seguiu a mesma tendência de resposta da matéria seca (quadrática), embora as doses para o perfilhamento máximo, ou 80 e $90 \%$ do máximo, tenham sido superiores às necessárias para a produção de matéria seca. Nesse estudo, a braquiária apresentou, em relação ao colonião, maiores perfilhamento e produção de matéria seca.

Em estudo de omissão de nutrientes, Morikawa (1993) constatou perfilhamento mais prolifico no Andropogon gayanus que no Brachiaria brizantha, sendo os nutrientes fósforo, nitrogênio e enxofre os que mais limitaram o perfilhamento das forrageiras. Abreu (1994), estudando o capimTanzânia, verificou que o suprimento de nitrogênio na forma de nitrato proporcionou maiores produções de matéria seca e de perfilhamento quando comparado com o suprimento de $25 \%$ ou mais do total de nitrogênio como amônio na solução.

Marques et al. (1995) trabalharam em Cambissolo álico com a Brachiaria brizantha e Andropogon gayanus. Também verificaram que, depois do fósforo, o elemento mais limitante no perfilhamento foi o nitrogênio. Além disso, a omissão de enxofre não afetou o perfilhamento desses capins. Em estudo desenvolvido com capim-vencedor em solução nutritiva, Santos et al. (1995) observaram que a baixa disponibilidade de nitrogênio afetou 
significativamente o perfilhamento da planta.

Em estudo com Brachiaria brizantha, Monteiro et al. (1995) verificaram reduções significativas no número de perfilhos no tratamento em que se omitiu o enxofre, quando comparado ao tratamento completo.

Trabalhando em vasos com Latossolo Vermelho-Escuro, Faquin et al. (1995) observaram respostas significativas às aplicações de enxofre para o

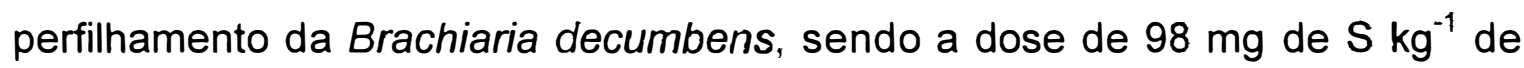
solo a que proporcionou o número máximo de perfilhos. Contudo, não foi constatada influencia desse nutriente no perfilhamento do capim-colonião.

\subsection{Atividade da redutase do nitrato}

Em solos oxidados, o nitrato é a principal forma de nitrogênio disponivel, assim como a mais absorvida pelas plantas. É necessario que ocorram algumas transformações do nitrato na planta para que o mesmo possa ser metabolizado pelo vegetal. Taiz \& Zeiger (1991) relataram que o ion nitrato, após ser absorvido pela planta, pode ser armazenado nos vacúolos das células das raízes ou ser translocado via xilema para a parte aérea, onde poderá ser armazenado ou reduzido. Nas plantas das regiões tropicais e subtropicais, essa redução ocorre principalmente na parte aérea da planta e independe da concentração externa desse ion, enquanto que em plantas das regiões temperadas a redução ocorre preferencialmente nas raízes.

A reação de redução do nitrato é catalisada pela redutase do nitrato, uma enzima que está presente em todas as partes da planta. $O$ aumento do conteúdo de nitrato pode ser resultado da intensificação da absorção de nitrato e da diminuição da atividade dessa enzima. A redutase do nitrato é importante no metabolismo da planta e sua atividade está relacionada com a taxa de 
assimilação de nitrato e, de alguma maneira, ao rendimento de matéria seca e ao teor de proteina na planta.

A atividade da redutase de nitrato também tem sido utilizada como indicadora do "status" de nitrogênio na planta e como parâmetro para aplicação de fertilizantes (Johnson et al., 1976). Beevers \& Hageman (1969) relataram que a atividade da redutase do nitrato pode ser induzida pela temperatura, intensidade luminosa e suprimento do nitrato.

Nambiar et al. (1988) observaram que a redução do nitrato pode ocorrer tanto nas raízes como nas folhas, dependendo da espécie e taxa de absorção. Em espécies tropicais e subtropicais, a redução do nitrato ocorre principalmente na parte aérea, independentemente da concentração externa desse ín. Em experimento com Brachiaria decumbens, Fernandes \& Freire (1976) concluíram que a atividade da redutase do nitrato pode ser usada para indicar o "status" do nitrogênio na planta quando se deseja evitar ação de fatores ambientais.

Fernandes et al. (1978) constataram que a atividade da redutase do nitrato em Brachiaria sp. apresentou alta e positiva correlação $(r=0,97)$ com o teor de nitrogênio protéico nas folhas e bainhas. O nitrato adicionado parceladamente, assim como o incremento de baixa dose de nitrogênio na forma mais reduzida, aumentou a atividade dessa enzima, parecendo indicar uma indução na síntese de compostos orgânicos com o aumento da atividade metabólica que resulta na absorção mais rápida de nitrato.

Trabalhando com capim-colonião e proporções de amônio e nitrato, Andrade (1994) constatou que a atividade "in vitro" da redutase do nitrato aumentou significativamente quando foram fornecidas ambas as fontes de nitrogênio, indicando certa ação estimuladora do íon amônio na atividade da enzima.

Duke \& Reisenauer (1986) citaram que o metabolismo de todas as 
plantas depende do enxofre e que a sua baixa disponibilidade causa disfunções básicas no metabolismo, que podem resultar em reduções no crescimento, na produção e na qualidade do material vegetal produzido. Além disso, em plantas deficientes em enxofre, a concentração de nitrogênio protéico decresce e aumenta a concentração de nitrogênio não protéico como nitrato, amidas e argininas (Friedrich \& Schrader, 1978). Esses autores citaram que a redução do nitrato e a síntese de proteínas são inibidas pela deficiência de enxofre. Também observaram que em cultura de milho deficiente em enxofre, a redução do nitrato e assimilação do amônio foram igualmente afetados. Reuveny et al. (1980) relataram que, em cultura de fumo, a atividade da redutase do nitrato foi drasticamente reduzida pela deficiência de enxofre. Esses autores concluíram que a atividade da redutase do nitrato é inibida pela acumulação de produtos finais da redução do nitrato (aminoácidos) quando há deficiência de enxofre. Citaram ainda que esse comportamento pode não ser regra geral para outras culturas. Srivastava (1980) relatou que o suprimento externo de nitrito, amônio e aminoácidos pode aumentar, diminuir ou ter pouco ou mesmo nenhum efeito sobre a atividade da redutase do nitrato nas plantas.

\subsection{Teor de clorofila no capim-braquiária}

A determinação indireta do teor de clorofila de algumas culturas vem sendo feita através do aparelho Chlorophyll Meter SPAD-502 (Soil Plant Analysis Development), desenvolvido pela Minolta no Japão. Este clorofilômetro expressa os resultados em valores de unidades SPAD e apresenta algumas vantagens, como ser portátil e leve, apresentar facilidade de manuseio e obtenção de leituras rápidas correspondentes ao teor de clorofila no limbo foliar (não havendo necessidade de destruição da parte amostrada), poder ser

usado em diversas condições ambientais a campo e predizer o aparecimento 
inicial da deficiência de nitrogênio (Minolta Camera Co, 1989).

O clorofilômetro vem sendo utilizado como ferramenta alternativa para avaliação da nutrição da planta. Ainda são escassas as informações de pesquisas correlacionando os resultados das leituras do clorofilômetro com os teores de nutrientes e o rendimento das diversas culturas.

A quantidade de leituras com o clorofilômetro para otenção do valor SPAD médio deve ser suficientemente representativa para que haja maior estabilidade dos resultados. Neste sentido, Yadava (1986) procedeu à medição do teor de clorofila pelo método convencional de laboratório e leitura pelo clorofilômetro em 22 espécies representando 14 famílias de plantas, e obteve os maiores coeficientes de correlação quando foram feitas 40 leituras no limbo foliar das plantas. Os valores SPAD variaram de 22,3 a 51,8 e corresponderam a 191,4 a $460,4 \mu \mathrm{mol} \mathrm{cm}{ }^{-1}$ de clorofila.

Campbell et al. (1990) avaliaram o efeito de doses de nitrogênio em Malus domestica Borkh e verificaram resposta linear positiva dos valores SPAD e do teor de clorofila. Os autores constataram respostas diferenciadas das plantas em função das épocas (inverno e verão) e entre as condições de cultivo. Em casa-de-vegetação, os valores SPAD foram de 36 a 64 e corresponderam a 4,8 a $15 \mu \mathrm{g} \mathrm{cm}^{-2}$ de clorofila extraída, enquanto que no campo os resultados foram mais altos, sendo os valores SPAD de 42 a 64 no primeiro ano e de 52 a 67 no segundo ano, o que correspondeu a 20,6 a 80,0 e 40,0 a $80,0 \mu \mathrm{g} \mathrm{cm}^{-2}$ de clorofila extraída, respectivamente. Resultados referentes à utilização do clorofilômetro para determinação do estado nutricional em gramíneas forrageiras não foram encontrados na literatura.

Resultados disponíveis na literatura e referentes à cultura do arroz (Chubachi et al.,1986; Turner \& Jund, 1991; Peng et al., 1993) demonstram que a utilização do clorofilômetro é uma alternativa para expressar, com precisã e de forma indireta, o teor de clorofila da planta assim como poder estimar a 
concentração de nitrogênio na folha em função do peso seco além de predizer a necessidade de uso de fertilizante nitrogenado.

Peng et al. (1995) confirmaram a utilização eficiente do Chlorophyll Meter SPAD 502 na diagnose do "status" de nitrogênio em cultura de arroz. Esses autores obtiveram leituras do clorofilômetro que variaram entre 35 e 63 unidades de valor SPAD, em função da idade da planta.

Piekielek \& Fox (1992) destacaram o uso do clorofilômetro em predizer respostas da cultura do milho à fertilização nitrogenada. Nas condições desse cultivo, a leitura em unidades de valor SPAD de 43,3 foi estabelecida como nivel crítico para produção de grãos. Smeal \& Zang (1994) obtiveram alta correlação de leituras do clorofilômetro em unidades de valor SPAD com resultados das análises químicas de nitrogênio no tecido foliar da cultura de milho. Nesse estudo, determinaram que o nivel crítico para esta cultura foi de 52 unidades de valor SPAD e consideraram o uso do clorofilômetro como importante ferramenta para o manejo da fertirrigação. Piekielek et al. (1995) avaliaram a suficiência de nitrogênio na cultura do milho e definiram que os valores SPAD de 52 a 56 foram considerados adequados para a nutrição da planta. Para essa mesma cultura, Malavolta et al. (1997) consideraram como adequados os valores SPAD entre 45 e 48 unidades.

Avaliando a cultura do trigo no inverno quanto à fertilização nitrogenada, Fox et al. (1994) relataram que os resultados através do clorofilômetro foram mais precisos que os baseados na concentração de nitrogênio para estimar a necessidade de fertilizantes nitrogenados. Esses autores definiram como nivel crítico para a cultura do trigo a leitura de 46 unidades de valor SPAD. Malavolta et al. (1997) sugeriram que, na cultura do trigo, a amostragem seja feita no meio da primeira folha totalmente expandida a partir da ponta da planta, e consideraram os valores SPAD entre 48 e 52 como adequados. 
Mayol (1996), estudando a influência de doses de ferro no teor de clorofila em dois cultivares de arroz, obteve alta correlação entre os teores de ferro e os valores determinados pelo clorofilômetro, cujas leituras variaram de 39 a 45 unidades SPAD.

Segundo Friedrich \& Schrader (1978), plantas deficientes em enxofre diminuem a taxa fotossintética, a concentração de clorofila nas folhas decrescem drasticamente e os cloroplastos podem sofrer degeneração. Nessas condições, a utilização do clorofilômetro pode ser uma alternativa viável para predizer, em valor SPAD, a concentração de clorofila na forrageira.

\subsection{Nível crítico e sintomatologia de deficiência de nitrogênio e enxofre}

A planta em nutrição adequada apresenta, em seus tecidos, todos os elementos em quantidades e proporções necessárias para atingir altas produções(Malavolta, 1997).

A avaliação do estado nutricional da planta pode ser realizada através da diagnose foliar, que consiste na determinação de teores de nutrientes no material vegetal amostrado. Nesse caso, a folha é considerada o órgão que melhor reflete as diferenciações no suprimento de nutrientes. O conhecimento das concentrações dos nutrientes nos compartimentos da planta é fundamental para o planejamento do sistema de produção a ser desenvolvido.

Andrews (1965) conceituou nivel crítico como sendo a concentração do nutriente na planta em que se obtém a máxima produção. Ulrich \& Hills (1967) definiram como nivel crítico a concentração correspondente a uma produção de $90 \%$ daquela considerada adequada. Dow \& Roberts (1982) consideraram o nivel crítico de um elemento na planta como sendo uma faixa 
de concentração e não apenas um ponto correspondente às condições de crescimento ótimo. Okhi (1987) também definiu que o nível crítico do nutriente é a concentração que reduz em $10 \%$ a produção máxima, o qual é definido como nível crítico de deficiência. A concentração tóxica do nutriente que reduz na mesma proporção é conhecida como nível crítico tóxico. Malavolta et al. (1997) consideraram essas condições como nivel crítico inferior e superior, respectivamente.

Estudos referentes à determinação do nível crítico de nitrogênio nos componentes das gramíneas forrageiras não foram encontrados na literatura. Entretanto, tem-se observado valores de nível crítico de enxofre para algumas forrageiras.

Resultados relativos a diversas gramíneas foram apresentados por Smith \& Siregar (1983), que sugeriram concentrações de S-total nessas plantas da ordem de $0,07 \%$ a $0,11 \%$ como nível crítico desse elemento. Resultados semelhantes foram obtidos por Hoffmann (1992) em estudos com Brachiaria decumbens.

No primeiro crescimento do capim-braquiária, Faquim et al. (1995a) obtiveram o nivel crítico de enxofre para 80 e 90\% da produção máxima da parte aérea de 0,9 e $1,0 \mathrm{~g} \mathrm{~kg}^{-1}$ de matéria seca e nas folhas novas de 0,9 e 1,2 $\mathrm{g}$ de $\mathrm{S} \mathrm{kg}^{-1}$ de matéria seca, respectivamente. No segundo crescimento o nível crítico foi de 1,5 e $2,4 \mathrm{~g}_{\text {de }} \mathrm{S} \mathrm{kg}^{-1}$ de matéria seca, sendo explicada tal diferença devido ao efeito de concentração deste nutriente nessa parte da planta. No primeiro crescimento do capim-colonião, o nível crítico de enxofre na parte aérea foi 0,9 e $1,1 \mathrm{~g} \mathrm{Se} \mathrm{kg}^{-1}$ de matéria seca, e nas folhas novas de 0,8 e $1,0 \mathrm{~g}_{\text {de } S \mathrm{~kg}^{-1}}$ de matéria seca. Rao et al. (1996) citaram que em capimbraquiária o nível crítico de enxofre na parte aérea foi de $1,6 \mathrm{~g}_{\text {de }} \mathrm{S} \mathrm{kg}^{-1}$ de matéria seca.

A identificação visual da deficiência nutricional da planta é feita 
normalmente observando-se folhas, que por falta ou excesso de um determinado elemento expressa uma sintomatologia característica. A sintomatologia da deficiência de nitrogênio ou enxofre em gramíneas forrageiras depende muito da espécie avaliada e da disponibilidade destes nutrientes para as plantas.

Werner (1986) relatou que, nas gramíneas, a deficiência de nitrogênio é mais intensa nas folhas mais velhas que apresentam secamento acelerado e morte prematura, enquanto que na deficiência de enxofre, o amarelecimento primeiro ocorre nas folhas mais novas, precedendo as mais velhas que tendem a permanecerem vivas por mais tempo.

Mikkelsen \& Camberato (1995) citaram que a avaliação de sintomatologia visual causada pela deficiência de nitrogênio e de enxofre, frequentemente é confundida porque ambos são essenciais para a formação da molécula de clorofila, e que baixa concentração destes nutrientes no tecido da planta resultam em uma coloração verde pálido. Afirmaram que os sintomas são mais pronunciados em folhas recentemente formadas naquelas plantas deficientes em enxofre, devido à baixa redistribuição deste nutriente dentro da planta.

Santos et al. (1995) verificaram sintoma visual característico de deficiência de nitrogênio no capim-vencedor em dose zero e até aplicação de doses com $126 \mathrm{mg}$ de $\mathrm{N} \mathrm{L}^{-1}$ de solução. Monteiro et al. (1995) observaram sintomas visuais de deficiência de enxofre no capim-Marandu no tratamento onde houve omissão de enxofre. 


\section{DIAGNOSE NUTRICIONAL E RESPOSTAS DO CAPIM- BRAQUIÁRIA SUBMETIDO A DOSES DE NITROGÊNIO}

\subsection{Resumo}

O experimento foi realizado em casa-de-vegetação no período de dezembro de 1995 a fevereiro de 1996, com Brachiaria decumbens Stapf. cv. Basilisk cultivada em solução nutritiva, utilizando sílica como substrato. Foi utilizado o delineamento de blocos completos ao acaso, com quatro repetições. As plantas foram colhidas aos 39 dias do transplante para os vasos e novamente 31 dias após o primeiro corte. Foram avaliadas oito doses de nitrogênio $\left(0 ; 14 ; 42 ; 126 ; 210 ; 294 ; 378\right.$ e $\left.462 \mathrm{mg} \mathrm{L}^{-1}\right)$ na produção de matéria seca, no número de perfilhos, na atividade da redutase do nitrato, no teor de clorofila e na concentração e no acúmulo de nitrogênio na planta. As doses de nitrogênio proporcionaram aumentos na produção de matéria seca da parte aérea e das raízes e no número de perfilhos da forrageira. A atividade da redutase do nitrato e o teor de clorofila foram mais influenciados no primeiro crescimento do que no segundo. A concentração de nitrogênio foi mais baixa nos colmos+bainhas que nos demais componentes da parte aérea e o acúmulo do nutriente foi menor nas folhas não-expandidas e maior nos colmos+bainhas, nos dois crescimentos. As lâminas de folhas novas mostraram-se as mais indicadas para a avaliação da nutrição em nitrogênio na Brachiaria decumbens.

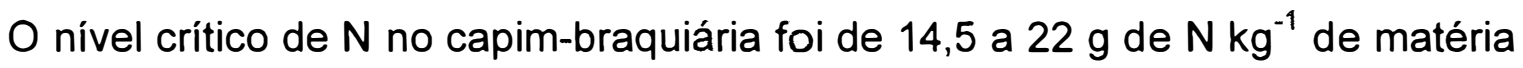
seca, o qual corresponde a valor SPAD de 37 a 49, respectivamente. 


\subsection{Summary: NUTRIENT DIAGNOSIS AND RESPONSES OF Brachiaria decumbens Stapf TO NITROGEN RATES}

An experiment was carried out in a greenhouse with Brachiaria decumbens Stapf. cv. Basilisk from December 1995 to February 1996. Plants were grown in nutrient solution, using plastic pots with ground quartz as substrate. A complete randomized block design was used, with four replications. Plants were harvested 39 days after transplanting the seedlings to the pots and again 31 days after the first harvest. Eight rates of nitrogen were used $(0 ; 14$; 42; 126; 210; 296; 378 and $462 \mathrm{mg} \mathrm{L}^{-1}$ ). Dry matter yield, tiller number, nitrate reductase activity, chlorophyll concentration and concentration and content of nitrogen in the plant were evaluated. Nitrogen rates provided increases on dry matter yield of plant tops and roots and in tiller number. Nitrate reductase activity and chlorophyll concentration had higher increases in the first harvest than in the second. Nitrogen concentration was lower in stems+sheaths than in other plant parts and the content of this nutrient was lower in the non-expanded leaves and higher in the stems+sheaths than in other plant parts. The young leaf blades are recommended for evaluating the nutritional status of nitrogen in Brachiaria decumbens. The critical level of $\mathrm{N}$ in the Brachiaria decumbens is in the range of 14.5 to $22.0 \mathrm{~g}$ of $\mathrm{N} \mathrm{kg}^{-1}$ of dry matter which corresponded to SPAD value from 37 to 49 , respectively.

\subsection{Introdução}

O capim Brachiaria decumbens Stapf. é bastante difundido nas regiōes brasileiras, principalmente nas áreas de Cerrado, que se caracterizam pela relativa acidez e baixa fertilidade dos solos. Apesar da destacada 
importância, essa gramínea vem apresentando queda de produção de matéria seca no decorrer de ciclos subsequentes de pastejo.

Em levantamento realizado pelo Instituto Agronômico e pelo Instituto de Zootecnia, a Brachiaria decumbens já apresentava, nos primeiros anos da década de 80 , ocorrência em $92 \%$ dos municípios do Estado de São Paulo (Rocha, 1985). Segundo Meirelles (1993), o capim-braquiária deve ser a forrageira tropical com maior área cultivada no mundo, devido a sua grande expansão no Brasil.

Myers \& Robbins (1991) citaram que a deficiência de nitrogênio é o principal fator de degradação das pastagens cultivadas. Apesar de abundante na atmosfera na forma de $N_{2}$, na maioria dos solos apresenta-se com baixo teor. Este nutriente é constituinte de compostos orgânicos das plantas, entre os quais aminoácidos, proteínas, ácidos nucléicos e molécula de clorofila (Mengel \& Kirkby, 1987).

Sanzonowicz (1986) relatou que em pastagens estabelecidas há mais de cinco anos, o nitrogênio foi o principal nutriente limitante no rendimento em matéria seca das pastagens de Brachiaria ruziziensis e Brachiaria decumbens. Segundo Boin (1986), a produção de matéria seca de gramíneas, em resposta à adubação nitrogenada, dentro de limites, apresenta comportamento normalmente linear, variando fundamentalmente com a frequência de cortes e com as condições de solo e clima. Resposta diferencial em quatro braquiárias submetidas a doses de nitrogênio em solos de cerrrado foi observada por Pereira (1986), tendo sido a Brachiaria decumbens cv. IPEAN a mais produtiva. Harding \& Grof (1978), estudando efeito de nitrogênio em Brachiaria decumbens, consideraram a dose de $365 \mathrm{~kg}$ de N ha- $\mathrm{ano}^{-1}$ como ótima em termos de produção de matéria seca e aproveitamento de nitrogênio.

De acôrdo com Langer (1974), o perfilho caracteriza a unidade estrutural e produtiva das gramíneas forrageiras. $O$ número e tamanho desses 
perfilhos, influenciam a produtividade da pastagem. Langer (1963) citou que a capacidade de perfilhamento das gramineas forrageiras depende de muitos fatores, entre os quais destacam-se as caracteristicas genéticas de cada espécie e o seu estado nutricional. Esse autor enfatizou que o nitrogênio é o nutriente mais importante para o perfilhamento de gramíneas estabelecidas e, em condições de deficiência, o número de perfilhos na planta é significativamente reduzido.

A avaliação da atividade da redutase de nitrato também tem sido empregada como indicadora do "status" de nitrogênio na planta e como parâmetro para aplicação de fertilizantes (Johnson et al., 1976).

A redutase do nitrato é importante no metabolismo da planta e sua atividade está relacionada à taxa de assimilação de nitrato e de alguma maneira, ao rendimento produtivo e ao teor de proteina na planta.

Uma outra técnica para avaliação de deficiência de nitrogênio é aquela baseada na determinação do teor de clorofila. Esta pode ser feita através do Chlorophyll Meter SPAD 502 que vem sendo utilizado para expressar o teor de clorofila da planta assim como estimar a concentração de nitrogênio na folha e predizer a necessidade de uso de fertilizante nitrogenado (Minolta Camera Co. 1989). Respostas positivas têm sido verificadas em algumas culturas como milho (Smeal \& Zang, 1994); arroz (Peng et al. ,1995); trigo (Fox et al.1994), mas resultados com forrageiras são escassas na literatura.

Os objetivos deste estudo foram de avaliar respostas da Brachiaria decumbens Stapf cv. Basilisk a doses de nitrogênio em solução nutritiva quanto à produção de matéria seca, ao perfilhamento, à atividade da redutase do nitrato, ao teor de clorofila, o nivel crítico de nitrogênio e à concentração e o acúmulo desse nutriente na forrageira. 


\subsection{Material e métodos}

\subsubsection{Localização e espécie forrageira}

Este estudo foi desenvolvido em casa-de-vegetação localizada no Setor de Nutrição Mineral de Plantas, Departamento de Química, da Escola Superior de Agricultura "Luiz de Queiroz"-USP, Piracicaba, São Paulo. Cultivouse a espécie forrageira Brachiaria decumbens Stapf. no período de dezembro de 1995 a fevereiro de 1996 com temperatura ambiente variando de 27 a 38 ${ }^{\circ} \mathrm{C}$.

\subsubsection{Doses de nitrogênio, soluções nutritivas e delineamento experimental}

Foram utilizadas oito doses de nitrogênio correspondente a: 0,14 , $42,126,210,294,378$ e $462 \mathrm{mg}$ de $\mathrm{N} \mathrm{L}^{-1}$ de solução nutritiva. As soluções foram preparadas a partir da solução de Sarruge (1975), devidamente modificada para as oito doses de nitrogênio propostas. As soluções foram preparadas como demonstrado na Tabela 1.

Foi empregado o delineamento experimental de blocos completos ao acaso, com oito tratamentos e quatro repetições. Prevendo-se assegurar a produção de matéria seca necessária para as determinações das análises químicas dos componentes da parte aérea da planta (folhas não-expandidas, lâminas de folhas novas, lâminas de folhas velhas, colmos+bainhas) e das raízes, principalmente nos tratamentos com baixas doses de nitrogênio na solução, tratou-se de duplicar cada uma das repetições do experimento. Assim sendo, foram empregados um total de 64 vasos neste estudo. 
Tabela 1. Volumes $\left(m L L^{-1}\right)$ das soluções estoques empregados no preparo das soluções nutritivas para as doses de nitrogênio $\left(\mathrm{mg} \mathrm{L}^{-1}\right)$ estudadas.

\begin{tabular}{lc|c|c|c|c|c|c|c|c}
\hline \multirow{2}{*}{$\begin{array}{l}\text { Soluções } \\
\text { estoque }\end{array}$} & \multicolumn{8}{|c}{ Doses de nitrogênio $\left(\mathrm{mg} \mathrm{L}^{-1}\right)$} \\
\cline { 2 - 9 } $\mathrm{KNO}_{3}$ & $\mathrm{M}$ & - & 1 & 3 & 5 & 5 & 5 & 5 & 5 \\
$\mathrm{Ca}\left(\mathrm{NO}_{3}\right)_{2}$ & $\mathrm{M}$ & - & - & - & - & 5 & 5 & 5 & 5 \\
$\mathrm{NH}_{4} \mathrm{NO}_{3}$ & $\mathrm{M}$ & - & - & - & 2 & - & 3 & 6 & 9 \\
$\mathrm{KH}_{2} \mathrm{PO}_{4}$ & $\mathrm{M}$ & 1 & 1 & 1 & 1 & 1 & 1 & 1 & 1 \\
$\mathrm{KCl}_{\mathrm{KCl}}$ & $\mathrm{M}$ & 5 & 4 & 2 & - & - & - & - & - \\
$\mathrm{CaCl}_{2}$ & $\mathrm{M}$ & 5 & 5 & 5 & 5 & - & - & - & - \\
$\left.\left.\mathrm{Mg}_{(\mathrm{SO}}\right)_{4}\right)$ & $\mathrm{M}$ & 2 & 2 & 2 & 2 & 2 & 2 & 2 & 2 \\
$\mathrm{Micro}-\mathrm{Fe}$ & $*$ & 1 & 1 & 1 & 1 & 1 & 1 & 1 & 1 \\
$\mathrm{Fe}-\mathrm{EDTA}$ & $*$ & 1 & 1 & 1 & 1 & 1 & 1 & 1 & 1 \\
\hline
\end{tabular}

* A solução de micronutrientes teve a seguinte composição $\left(\mathrm{g} \mathrm{L}^{-1}\right): \mathrm{H}_{3} \mathrm{BO}_{3}$, 2,86; $\mathrm{MnCl}_{2} \cdot 4 \mathrm{H}_{2} \mathrm{O}, 1,81 ; \mathrm{ZnCl}_{2}, 0,10 ; \mathrm{CuCl}_{2}, 0,04$ e $_{2} \mathrm{MoO}_{4} \cdot \mathrm{H}_{2} \mathrm{O}, 0,02$.

** Dissolveram-se $26,1 \mathrm{~g}$ de EDTA dissódico em $286 \mathrm{~mL}$ de $\mathrm{NaOH} \mathrm{N}$, misturando-se com $24.0 \mathrm{~g}$ de $\mathrm{FeSO}_{4} \cdot 7 \mathrm{H}_{2} \mathrm{O}$, arejando-se por uma noite e completando-se a $1 \mathrm{~L}$ de água deionizada.

\subsubsection{Instalação e condução do experimento}

As sementes de braquiária foram germinadas em bandejas plásticas contendo areia lavada em água corrente e posteriormente em água deionizada. Vasos plásticos com capacidade para 3,6 L foram preenchidos com sílica apresentando granulometria em torno de $3 \mathrm{~mm}$ de diâmetro e livre de impurezas. 
Após oito dias da semeadura foram transplantadas, para cada vaso, 15 mudas das plantas com cerca de $5 \mathrm{~cm}$ de altura e adicionado um litro de solução diluída em $30 \%$ da concentração total correspondente a cada dose de nitrogênio. Inicialmente esta solução permaneceu nos vasos durante o dia e a noite, sendo circulada através da sílica três vezes ao dia, por um período de três dias e posteriormente drenada à noite. Nesta fase procederam-se desbastes periódicos até permanecerem cinco plantas por vaso. Após quatro dias do transplante, as soluções com concentração definitiva foram adicionadas nos vasos e trocadas a cada 14 dias. Durante o período do experimento, a cada três dias, os vasos eram remanejados dentro de cada bloco.

Aos 39 dias após o transplante procedeu-se ao primeiro corte, a uma altura de dois $\mathrm{cm}$ do colo das raizes, e as plantas foram separadas em folhas não-expandidas, lâminas de folhas novas (lâminas das duas folhas superiores totalmente expandidas), lâminas de folhas velhas (lâminas das demais folhas) e em colmos+bainhas (colmo propriamente dito mais as bainhas que foram mantidas a eles circundadas). As folhas foram consideradas totalmente expandidas quando apresentavam a lígula visivel.

Aos 31 dias após o primeiro corte realizou-se o segundo corte, no colo das raizes, e as plantas foram separadas segundo o mesmo critério, sendo que as raizes também foram separadas e lavadas. $O$ material vegetal foi colocado para secar em estufa com circulação de ar, à temperatura de $65^{\circ} \mathrm{C}$, durante 72 horas, até massa constante.

\subsubsection{Produção de matéria seca}

A produção de matéria seca foi determinada para a parte aérea através da soma do peso seco dos seus componentes (folhas não-expandidas, 
lâminas de folhas novas, lâminas de folhas velhas e colmos+bainhas) e para as raizes das plantas, após a secagem em estufa.

\subsubsection{Análises químicas}

Para obtenção do material vegetal juntaram-se as amostras colhidas em duplicata nos vasos. As amostras foram moídas em moínho tipo Wiley e acondicionadas em sacos plásticos. A determinação da concentração de nitrogênio total em cada componente da parte aérea e nas raízes foi executada conforme metodologia de Sarruge \& Haag (1974). A digestão sulfúrica foi utilizada para a obtenção do extrato e a determinação do nitrogênio total envolveu a destilação em aparelho semi-micro Kjeldahl e titulação com ácido sulfúrico.

A atividade da redutase do nitrato foi determinada utilizando-se a metodologia descrita por Mulder et al. (1959). Aos 21 e 27 dias do primeiro e segundo crescimentos da forrageira, respectivamente, foram coletadas amostras da lâmina foliar da segunda folha completamente expandida (no sentido do ápice para base). Antes da coleta das folhas, as plantas eram colocadas em câmara-de-crescimento com duas horas de exposição à luz e temperatura constante de $28{ }^{\circ} \mathrm{C}$, para padronização e redução da interferência de fatores ambientais na atividade enzimática. As leituras dos extratos foram realizadas em fotocolorímetro a $540 \mathrm{~nm}$ e utilizou-se a reta padrão de nitrito e análise de regressão para cálculo da concentração de $\mathrm{NO}_{2}$ no meio.

O Chlorophyll Meter SPAD-502, (Soil-Plant Analysis Development Section, Minolta Camera Co., Osaka, Japan) foi utilizado para a determinação de medidas de clorofila em valor SPAD em folhas intactas, correspondente à quantidade de clorofila presente na amostra. Os espectros de absorção são 
determinados com base na quantidade de luz transmitida pela folha amostrada em dois comprimentos de onda, sendo nas áreas do vermelho aproximadamente em $650 \mathrm{~nm}$ e infravermelho em $940 \mathrm{~nm}$, onde os picos de absorção são máximo e mínimo, respectivamente. Nesta faixa, as leituras não são influenciadas pela presença de outros pigmentos. A luz transmitida é convertida em sinais elétricos, que são digitalizados e microprocessados para cálculo em valor SPAD da medida de clorofila (Minolta Câmera Co., 1989).

As leituras do clorofilômetro foram realizadas aos 24 e 25 dias do primeiro e segundo crescimentos da forrageira, no terço médio do limbo da segunda folha completamente expandida a partir do ápice de cada planta. Este procedimento baseou-se em uma avaliação prévia dos valores de clorofila em unidades SPAD, feita ao longo do comprimento do limbo foliar e em cada folha da planta. Esses resultados preliminares demonstraram que a parte mediana das folhas (terço médio foliar) apresentou melhor estabilidade dos valores SPAD, uma vez que no terço basal os valores obtidos foram menores e na extremidade das folhas foram observadas maiores variações nos resultados. Considerou-se como valor representativo de cada repetição a média de dez leituras executadas por vaso no limbo foliar das plantas nos respectivos tratamentos.

\subsubsection{Análises estatísticas}

Os resultados foram submetidos à análise estatística de variância e em função do nivel de significância no teste de $F$ para doses de nitrogênio, procedeu-se ao estudo de regressão polinomial ou teste de médias (Tukey 5\%), utilizando-se o programa estatístico SAS - Institute, 1989. 


\section{5 Resultados e discussão}

\subsubsection{Produção de matéria seca}

Os resultados demonstraram que a produção de matéria seca, tanto da parte aérea como das raízes da Brachiaria decumbens Stapf., variou significativamente $(P<0,01) \mathrm{com}$ as doses de nitrogênio na solução. Como demonstrado na Figura 1, as equações de regressão da produção de matéria seca com as doses de nitrogênio apresentaram ajustes ao modelo quadrático.

Derivando-se as equações de regressão, verificou-se que as máximas produções de matéria seca da parte aérea do primeiro e segundo crescimentos foram obtidas nas doses de 435 e $433 \mathrm{mg}$ de $\mathrm{N} \mathrm{L}^{-1}$ de solução, respectivamente. Essas doses foram mais elevadas que aquelas obtidas por Santos et al. (1995) para o capim-Vencedor, por Almeida \& Monteiro (1995) para o capim-coastcross 1 e por Corrêa (1996) para o capim-vencedor. Por outro lado, foram inferiores aquelas observadas por Corrêa (1996) para o capim-colonião.

Altas respostas da braquiária às doses de nitrogênio também foram observadas por Hoffmann (1992) que obteve máxima produção com $437 \mathrm{mg}$ de $\mathrm{N} \mathrm{kg}^{-1}$ de solo. Apesar dos diferentes substratos, esta forrageira demonstra apresentar expressivas respostas às doses mais elevadas de nitrogênio.

Os resultados deste estudo também confirmam os descritos por Vicente-Chandler et al. (1972) com Brachiaria ruziziensis em Porto Rico, que obtiveram respostas até $400 \mathrm{~kg}$ de $\mathrm{N} \mathrm{ha}^{-1}$ e pelo CIAT (1978) e Carvalho et al. (1991), que observaram respostas significativas da Brachiaria decumbens quando submetida até a dose de $400 \mathrm{~kg}$ de $\mathrm{N} \mathrm{ha}^{-1} \mathrm{ano}^{-1}$. 


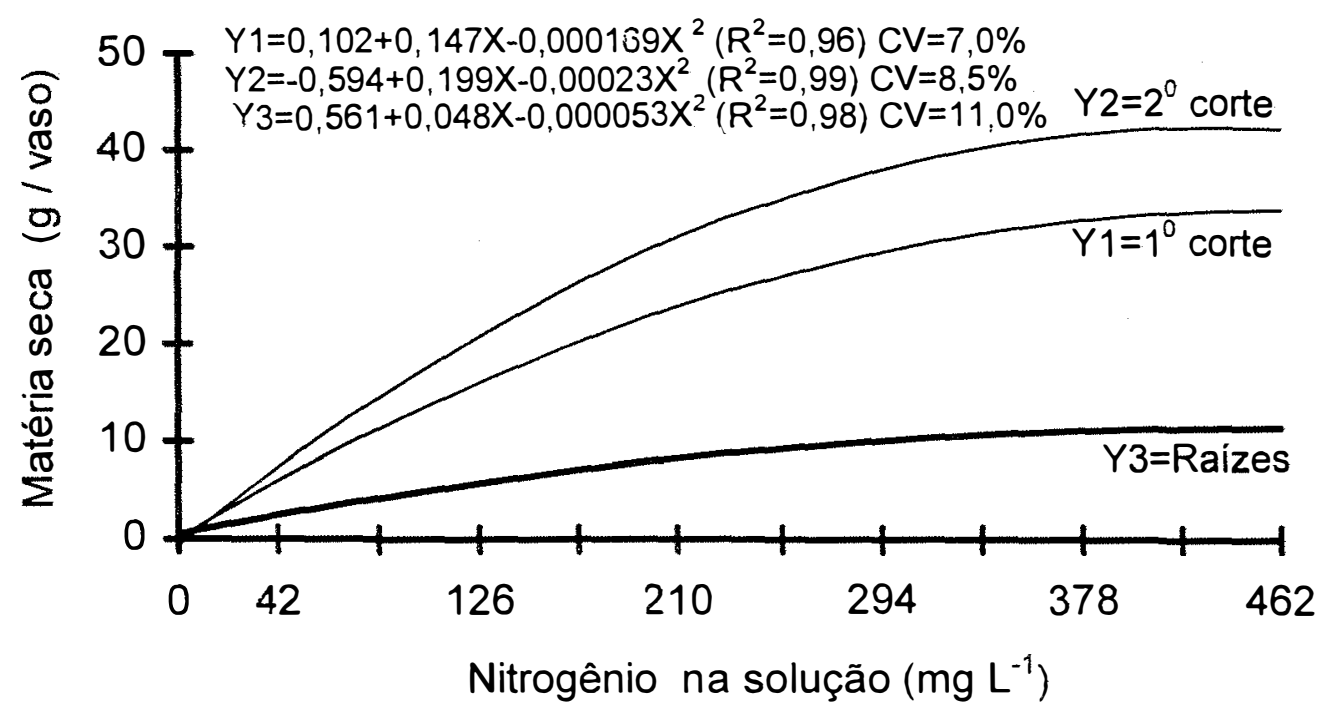

Figura 1- Produção de matéria seca da parte aérea e das raizes da Brachiaria decumbens Stapf., no primeiro e segundo cortes, em função das doses de nitrogênio. $C V=$ Coeficiente de variação.

A resposta observada ao nitrogênio para o capim braquiária caracteriza que a concentração de nitrogênio de $210 \mathrm{mg} \mathrm{L}^{-1}$ de solução estabelecida no tratamento completo da solução de Sarruge (1974), não é suficiente para atender às exigências para a expressão do máximo potencial produtivo da braquiária. Analisando as equações de regressão apresentadas

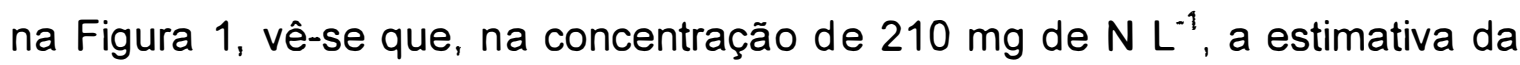
produção média de matéria seca da parte aérea foi de $71 \%$ em relação às máximas produções nos dois crescimentos da forrageira.

Em condições de baixa disponibilidade de nitrogênio, situação frequentemente encontrada em áreas de pastagens extensivas com capimbraquiária, observou-se que o desenvolvimento da parte aérea e das raizes foi muito reduzido. Esses efeitos confirmam os resultados observados por Sanzonowicz (1986) em Brachiaria ruziziensis e em Brachiaria decumbens. 
Observou-se que o valor absoluto da matéria seca da parte aérea produzida no segundo crescimento da forrageira foi superior ao primeiro, isto para todas as doses de nitrogênio avaliadas. Essa diferença de produção ocorreu de forma crescente com o aumento da concentração de nitrogênio na solução. Foi observado que a máxima produção de matéria seca obtida no segundo crescimento foi $33 \%$ superior à máxima produção do primeiro crescimento. Esta diferença pode ser atribuída à maior quantidade de nutrientes absorvidos no segundo cultivo da planta, uma vez que o volume radicular é mais intenso e a planta já se encontrava estabelecida. Nesta condição, a presença de maior quantidade de carboidratos acumulados nas raizes deve ter favorecido o processo inicial de rebrota da forrageira, induzindo, em menor tempo, o aparecimento de folhas fotossinteticamente ativas. Além disso, a diferença na altura dos dois cortes da forrageira também contribuiu para a maior produção de matéria seca no segundo crescimento.

Ainda na Figura 1, através da equação de regressão verifica-se que a máxima produção de matéria seca das raizes da braquiária, foi obtida na dose de $453 \mathrm{mg}$ de $\mathrm{N} \mathrm{L}^{-1}$ de solução. Essa produção de matéria seca das raizes $(11,43 \mathrm{~g} / \mathrm{vaso})$ foi equivalente aos valores obtidos por Corrêa (1996) para os cultivares Colonião e Vencedor.

A quase totalidade das publicações confirma o significativo efeito do nitrogênio no desenvolvimento das plantas forrageiras (Novoa, 1981; Corsi, 1984; Gomide, 1989; Corrêa, 1996), cujas respostas diferem em função da magnitude da espécie, do clima, das doses de nutriente e do manejo das plantas (Werner, 1986).

Tem-se dado prioridade a estudos com nutrientes em forrageiras consideradas com maior potencial produtivo, como exemplo o gênero Panicum, que em geral apresentam maior demanda pelos nutrientes, além de maior sensibilidade ao manejo da fertilidade do solo. Entretanto, o capim Brachiaria 
decumbens, como demonstrado, apresenta potencialidade de resposta na produção de matéria seca quando submetido a doses mais elevadas de nitrogênio. Assim, fica evidente a necessidade de se ajustar de forma adequada a adubação nitrogenada para esta forrageira.

$\mathrm{Na}$ figura 2 é apresentada ilustração do efeito das doses de nitrogênio no desenvolvimento da parte aérea e das raízes da braquiária decumbens.

\subsubsection{Número de perfilhos no capim-braquiária}

Os resultados apresentados na Figura 3 demonstram que o aumento da concentração de nitrogênio na solução exerceu efeito significativo $(P<0,01)$ no número de perfilhos por vaso, tanto no primeiro como no segundo crescimento do capim-braquiária.

No primeiro crescimento foi constatado que o número de perfilhos aumentou significativamente até a dose $378 \mathrm{mg}$ de $\mathrm{N} \mathrm{L}^{-1}$ de solução, não diferindo, nesta dose, da dose máxima avaliada que foi de $462 \mathrm{mg}_{\text {de } \mathrm{N} \mathrm{L}^{-1}}$. Contudo, pode-se observar que o perfilhamento das plantas foi diminuto nas baixas concentrações do elemento, como comprovado também no rendimento de matéria seca.

No segundo crescimento, o número de perfilhos foi crescente com as doses de nitrogênio avaliadas. Neste caso, fica evidenciado que a dose máxima de nitrogênio (462 $\mathrm{mg} \mathrm{L}^{-1}$ ) pode não ter sido suficiente para definir a máxima produção de perfilhos na braquiária, no seu segundo crescimento. 

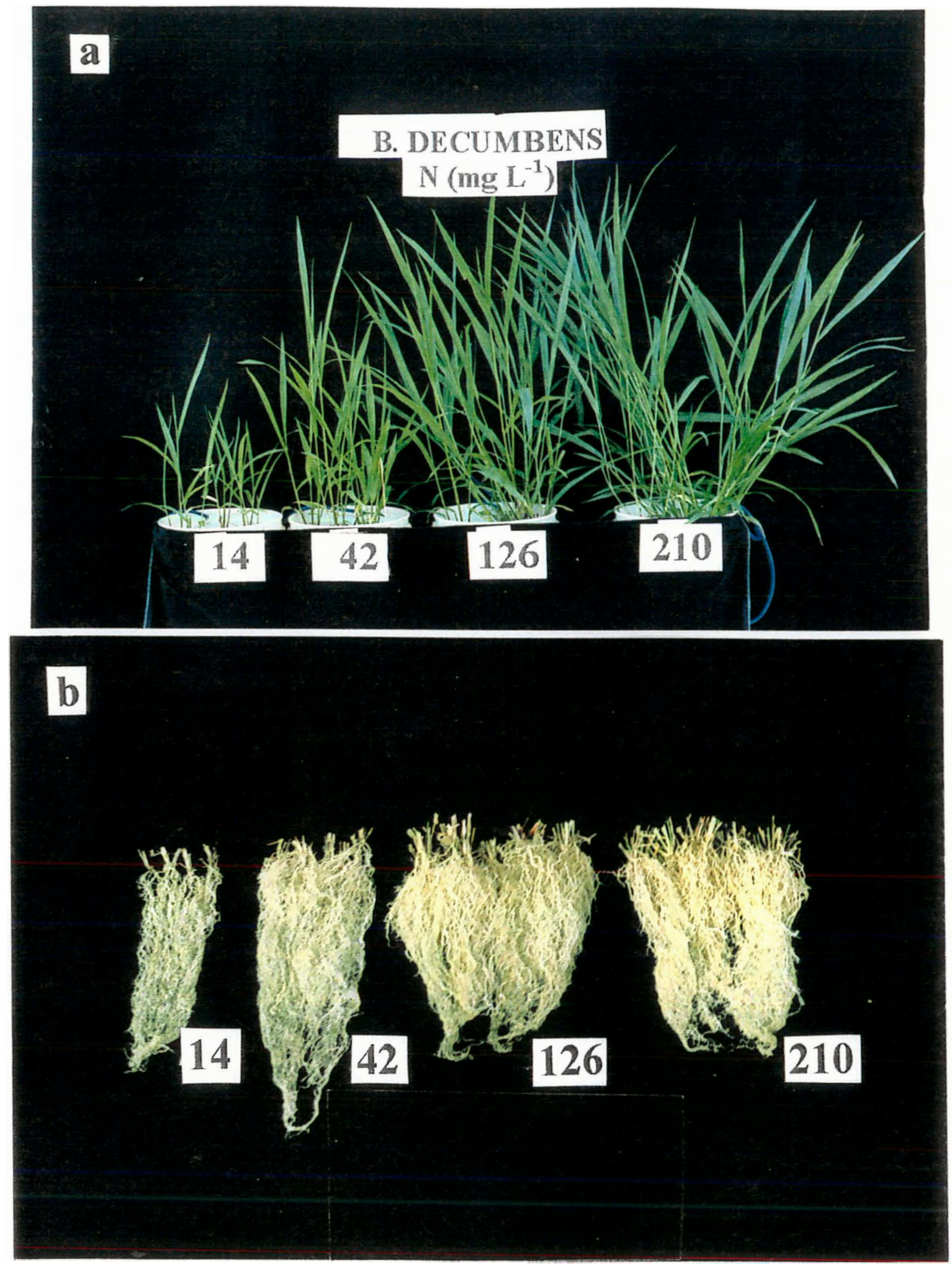

Figura 2 - llustração do efeito das doses de nitrogênio no desenvolvimento da parte aérea (a) e das raízes (b) de Brachiaria decumbens Stapf. 


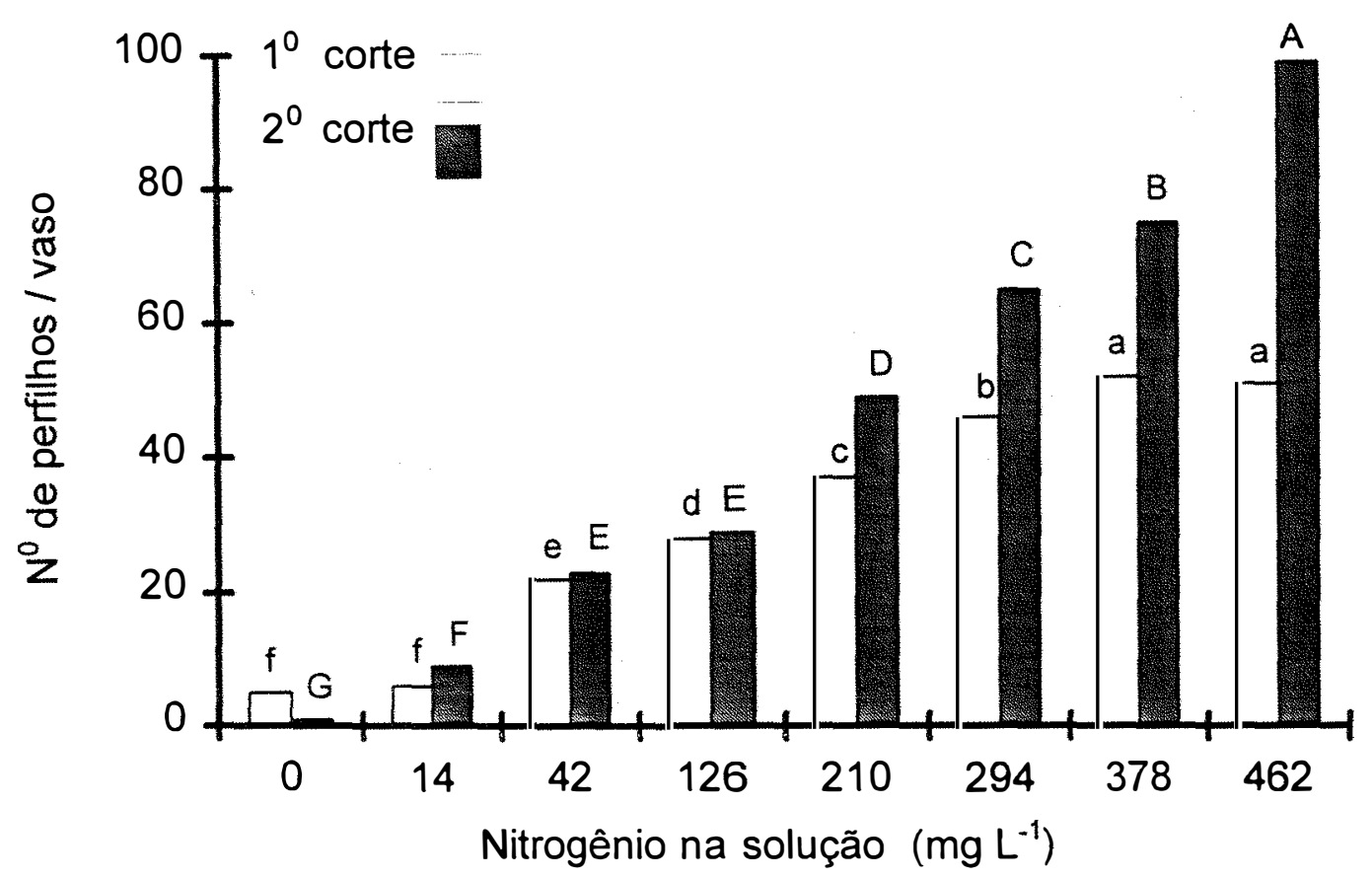

Figura 3 - Número de perfilhos nas cinco plantas da Brachiaria decumbens Stapf., no primeiro e segundo cortes em função das doses de nitrogênio na solução nutritiva. Letras diferentes entre doses de nitrogênio, para $\circ$ mesmo corte, indicam diferenças significativas ao nivel de $5 \%$ de probabilidade pelo teste de Tukey.

Comparando-se o perfilhamento, à época do primeiro com a do segundo corte, pode-se observar que houve maior número absoluto de perfilhos no segundo crescimento da forrageira nas doses mais elevadas de nitrogênio e que esta diferença foi mais representativa a partir da dose $210 \mathrm{mg}$ de $N^{-1}$ de solução. Esses resultados sugerem que esta forrageira pode apresentar taxa de perfilhamento ainda maior, quando cultivada em meio com concentrações de nitrogênio mais elevadas que as estudadas neste experimento. Por outro lado, não foram observadas diferenças representativas 


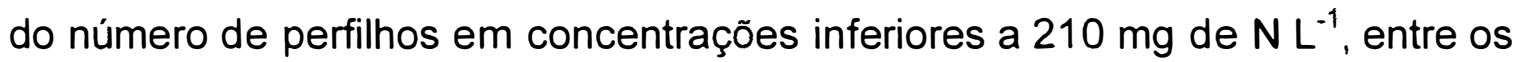
dois cultivos avaliados.

De acordo com Langer (1963), o surgimento e desenvolvimento de perfilhos está associado à atividade meristemática. Estes são considerado a unidade estrutural e produtiva das forrageiras, que em função de seu peso e do número de folhas lançadas, relaciona-se com a produção de matéria seca. A disponibilidade de nitrogênio tem pronunciado efeito na taxa de aparecimento foliar, podendo resultar em valores três a quatro vezes menores num alto nivel de deficiência quando comparado a um nivel não limitante. O efeito do nitrogênio na taxa de elongação foliar decorre do maior acúmulo deste nutriente na zona de alongamento da folha, mais especificamente na região de divisão celular (Gastal \& Nelson, 1994).

Nabinger (1997) relatou que a adequada disponibilidade de nitrogênio exerce efeitos positivos na taxa de aparecimento de perfilhos. Contudo, altas disponibilidades deste elemento podem determinar uma menor densidade de perfilhos na pastagem, devido ao mais rápido desenvolvimento do índice de área foliar e ao aumento na mortalidade. Deficiência de nitrogênio reduz ligeiramente a duração de vida das folhas, porém, a taxa de senescência aumenta devido ao pronunciado efeito do nitrogênio na taxa de aparecimento foliar e no tamanho da folha (Mazzanti \& Lemaire, 1994).

O destacado efeito do nitrogênio sobre o perfilhamento da braquiária, observado neste estudo, sustenta a importância deste nutriente sobre o aparecimento de perfilhos nas forrageiras, como já descrito por vários autores (Werner, 1986; Corsi, 1986; Morikawa, 1993; Santos et al., 1995).

Em condição de omissão de nitrogênio (dose 0 de nitrogênio) na solução nutritiva observou-se que no primeiro cultivo, cada planta tinha apenas a haste-mãe, sem qualquer perfilho basal, e teve seu crescimento paralizado logo no início do ciclo vegetativo. Nesta condição de ausência de nitrogênio, os 
efeitos foram drásticos no crescimento da forrageira, inclusive não havendo rebrota para produção de matéria seca. Este comportamento pode ser justificado pela presença de reservas de fontes nitrogenadas nas sementes serem suficientes apenas para estimular o início do crescimento da planta, 0 que não ocorreu na rebrota do capim após o corte.

Os resultados confirmam a destacada importância do nitrogênio para o número e o peso de cada perfilho, influenciando na produção de matéria seca e no estabelecimento do capim-braquiária. Resultados semelhantes foram encontrados por Monteiro \& Werner (1977); Abreu (1994) e Corrêa (1996) com cultivares de Panicum.

Ghisi et al. (1989) observaram que o maior número de perfilhos do cultivar Aruana em relação ao cultivar IZ-1 não se traduziu em maior produção de forragem. De acordo com Corsi (1986), o manejo da adubação nitrogenada é fundamental, uma vez que este elemento deverá estar disponivel no período em que a planta estimula os sítios de crescimento para a recomposição da parte aérea. No caso específico do Panicum maximum isto ocorre até sete dias após a desfolha.

Lawlor (1995) verificou que a deficiência de nitrogênio na cultura de trigo diminuiu o indice de área foliar, a taxa fotossintética das folhas $e$ estabeleceu uma menor taxa de perfilhamento. $O$ decréscimo na fotossintese líquida resultou em diminuição no conteúdo de fotoassimilados por unidade de área foliar.

\subsubsection{Atividade da redutase do nitrato}

A atividade da redutase do nitrato apresentou efeito diferenciado nos dois periodos de crescimento da gramínea forrageira e foi significativamente 
$(P<0,01)$ influenciada pelas doses de nitrogênio na solução. Os valores obtidos ajustaram-se a um modelo quadrático de regressão polinomial (Figura 4).

A atividade da enzima redutase do nitrato foi mais elevada no segundo crescimento da forrageira quando comparada com o primeiro, considerando todas as doses de nitrogênio na solução nutritiva. Seguramente este comportamento da enzima pode estar associado à maior absorção de nutrientes, induzindo o aumento na produção de material vegetativo e, consequentemente, maior quantidade de enzima presente nos componentes da planta.

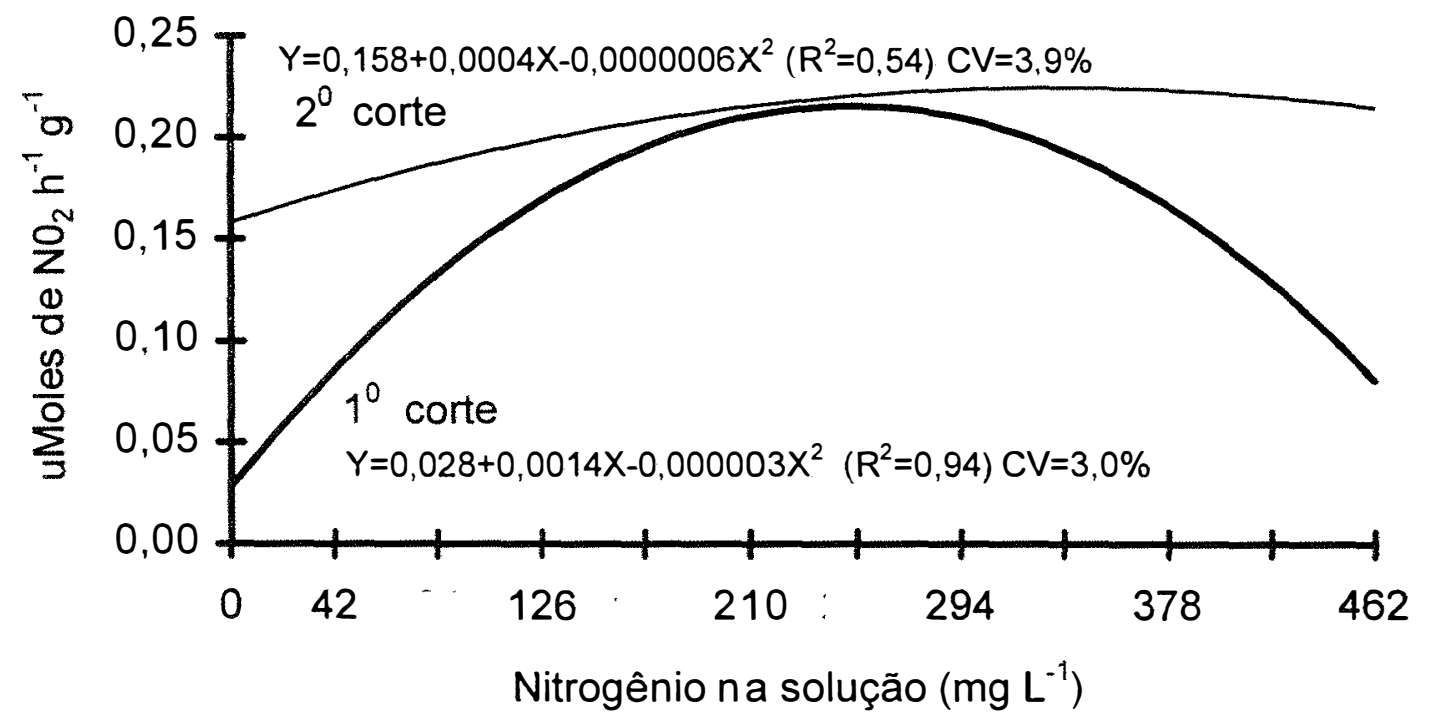

Figura 4 - Atividade da enzima redutase do nitrato no primeiro e segundo cortes da Brachiaria decumbens stapf., em função das doses de nitrogênio na solução. $C V=$ Coeficiente de variação.

Em condições de baixa disponibilidade de nitrogênio, como demonstrado na figura 4, no primeiro crescimento verificou-se que houve maior incremento da atividade da redutase do nitrato por unidade de nitrogênio adicionado. De acordo com Fernandes et al. (1978), o incremento em baixas doses de nitrogênio na forma mais reduzida aumentou a atividade dessa 
enzima. Este comportamento pode ser devido à maior relação entre a concentração de nitrogênio na solução e a quantidade enzimática presente na parte aérea, ainda pouco expressiva, uma vez que essa atividade foi avaliada aos 21 dias de crescimento da forrageira.

Aplicando o valor de $210 \mathrm{mg}$ de $\mathrm{N} \mathrm{L}^{-1}$ de solução nas equações de regressão apresentadas na Figura 4, verifica-se que as máximas atividades da redutase do nitrato foram de 0,19 e $0,21 \mu$ moles de $\mathrm{NO}_{2} \mathrm{~h}^{-1} \mathrm{~g}^{-1}$ de material vegetal fresco. Esses valores são em média duas vezes maiores que os encontrados por Abreu (1994), que obteve respostas lineares e valores de 0,10 $\mu$ moles de $\mathrm{NO}_{2} \mathrm{~h}^{-1} \mathrm{~g}^{-1}$ na média para os capins Gordura, Marandu e Tanzânia-1 e por Corrêa (1996) nos capins Vencedor, Tanzânia-1 e Colonião.

Verificou-se, através das equações de regressão, que as doses de 233 e $333 \mathrm{mg}$ de $\mathrm{N} \mathrm{L}^{-1}$ de solução foram as que promoveram as máximas atividades da enzima no primeiro e segundo crescimentos da planta, respectivamente. Entretanto, esses valores são inferiores àqueles encontrados para máxima produção de matéria seca e número de perfilhos da planta. Corrêa (1996) verificou que o capim-Vencedor apresentou redução da atividade enzimática até a dose de nitrogênio $232 \mathrm{mg} \mathrm{L}^{-1}$, aumentando a partir dessa concentração.

Neste estudo não se confirmou a ação estimuladora do ion amônio na atividade da redutase do nitrato, obtido por Andrade (1994) com capimcolonião. A análise estatística demonstrou que a atividade da redutase do nitrato apresentou baixos coeficientes de correlação entre a concentração de nitrogênio nas lâminas de folhas novas $(0,58$ e 0,50$)$ e os teores de clorofila medidos em valores $\operatorname{SPAD}(0,66$ e 0,67$)$, no primeiro e segundo crescimentos do capim-braquiária, respectivamente.

Os resultados desse estudo sugerem que a atividade da redutase do nitrato pode ser considerada como mais um parâmetro para avaliar o estado 
nutricional da planta em relação a disponibilidade de nitrogênio no sistema de produção, confirmando o que foi proposto por Johnson et al.(1976).

\subsubsection{Estimativa do teor de clorofila através do valor SPAD}

Os resultados das leituras de clorofila obtidos através do Chlorophyll Meter SPAD-502 na lâmina foliar do capim-braquiária em função das doses de nitrogênio estão mostrados na Figura 5. Observa-se que os valores SPAD tomados como referencial do teor de clorofila apresentaram ajuste ao modelo quadrático de regressão e foram significativamente $(P<0,01)$ influenciados pelas doses de nitrogênio na solução.

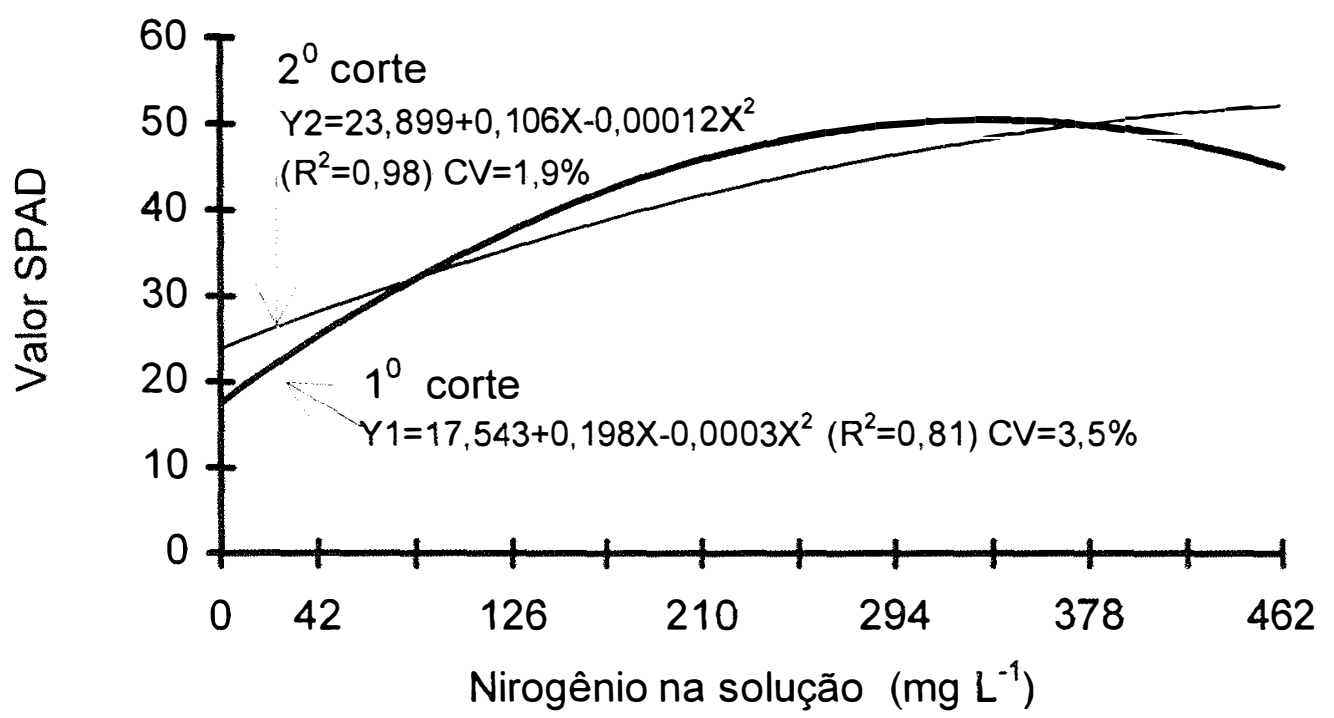

Figura 5 - Teor de clorofila determinado em unidade de valor SPAD no primeiro e segundo cortes da Brachiaria decumbens Stapf., em função das

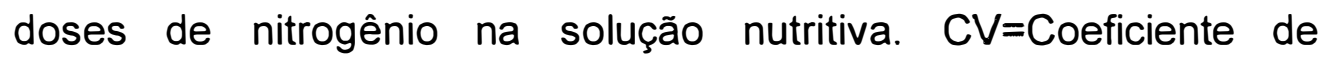
variação. 
A análise das equações de regressão demonstra que, no primeiro e no segundo crescimentos da forrageira. o teor de clorofila, expresso em valor SPAD, variou entre 17,0 e 50,2 e 23,9 e 52 para a condição de omissão e as doses do nutriente para máximo valor SPAD, que foram de 330 e $442 \mathrm{mg}$ de $\mathrm{N} \mathrm{L}^{-1}$, respectivamente.

Os valores SPAD obtidos neste estudo foram mais baixos que os observados por Campbell et al. (1990) em Malus domestica Borkh, por Peng et al. (1995) na cultura do arroz e por Piekielek et al. (1995) na cultura do milho.

Foi verificado alto coeficiente de correlação entre as leituras do clorofilômetro e as doses de nitrogênio no primeiro $(r=0,90)$ e no segundo crescimento $(r=0,99)$ da braquiária. Esses resultados indicam a possibilidade da utilização desta medida como mais uma alternativa viável para predizer o estado nutricional da forrageira quanto ao nitrogênio.

Blackmer \& Schepers (1993) confirmaram que o Chlorophyll Meter apresenta potencial para avaliar, com precisão, o "status" de nitrogênio na cultura do milho. Esses autores consideraram os valores de leitura SPAD 52,9 e 59 unidades como parâmetro ótimo para predizer o estado nutricional da cultura.

Fox et al. (1994) obtiveram o valor SPAD de 46 unidades como parâmetro do nível crítico para a cultura do trigo. Peng et al. (1995) confirmaram que Chlorophyll Meter pode ser utilizado para diagnosticar o "status" de nitrogênio em plantas de arroz e determinar a necessidade de fertiizante nitrogenado na cultura.

Neste experimento verificaram-se altos coeficientes de correlação entre os valores SPAD e a concentração de nitrogênio nos componentes da planta no primeiro e no segundo crescimento (folhas não-expandidas $=0,80 \mathrm{e}$ 0,83 ; lâminas de folhas novas $=0,91$ e 0,93 ; lâminas de folhas velhas $=0,87$ e 0,74 ; colmos + bainhas $=0,90$ e 0,93 e na parte aérea toda 0,91 e 0,88 ) da 
braquiária. Os resultados demonstraram serem as lâminas de folhas novas e os colmos+bainhas os componentes de maior correlação com os teores de clorofila medidos em valor SPAD. Devido a maior facilidade de amostragem, as lâminas de folhas novas devem ser o componente indicado para avaliação do teor de clorofila nessa forrageira.

\subsubsection{Concentração de nitrogênio nos componentes da parte aérea}

No primeiro crescimento do capim-braquiária, observou-se que a concentração de nitrogênio nos componentes da parte aérea (folhas nãoexpandidas, lâminas de folhas novas, lâminas de folhas velhas $e$ colmos+bainhas) apresentou respostas significativas $(P<0,01)$ para as doses de nitrogênio na solução.

No primeiro crescimento da forrageira (Figura 6), utilizando-se os valores das equações de regressão, verifica-se que houve pequena variação na concentração de nitrogênio nas folhas não-expandidas, nas lâminas de folhas novas e nas lâminas de folhas velhas em função das doses desse nutriente na solução. Observou-se que colmos+bainhas, mesmo apresentando um comportamento linear de respostas para as doses de nitrogênio, foi o componente da planta que apresentou as mais baixas concentrações de nitrogênio. A concentração de nitrogênio nas lâminas de folhas novas também teve efeito linear com variação de 12,6 a $27,5 \mathrm{~g}$ de $\mathrm{N} \mathrm{kg}^{-1}$ de matéria seca, nos limites das doses estudadas. Isso demonstra que nestes componentes da parte aérea a concentração de nitrogênio pode ser ainda mais elevada se forem empregadas doses superiores às avaliadas neste estudo.

Nas folhas não-expandidas e nas lâminas de folhas velhas a concentração de nitrogênio ajustou-se ao modelo quadrático de regressão. 
Utilizando-se as respectivas equações de regressão vê-se que nas folhas nãoexpandidas a dose de $406 \mathrm{mg}$ de $\mathrm{N} \mathrm{L}^{-1}$ foi a que proporcionou a máxima concentração de nitrogênio (23,8 $\mathrm{g}_{\text {de }} \mathrm{N} \mathrm{kg}^{-1}$ de matéria seca), enquanto que nas lâminas de folhas velhas a máxima concentração $\left(21,4 \mathrm{~g} \mathrm{de}^{\mathrm{N}} \mathrm{kg}^{-1}\right.$ de matéria seca) foi obtida na dose de $433 \mathrm{mg}$ de $\mathrm{N} \mathrm{L}^{-1}$.

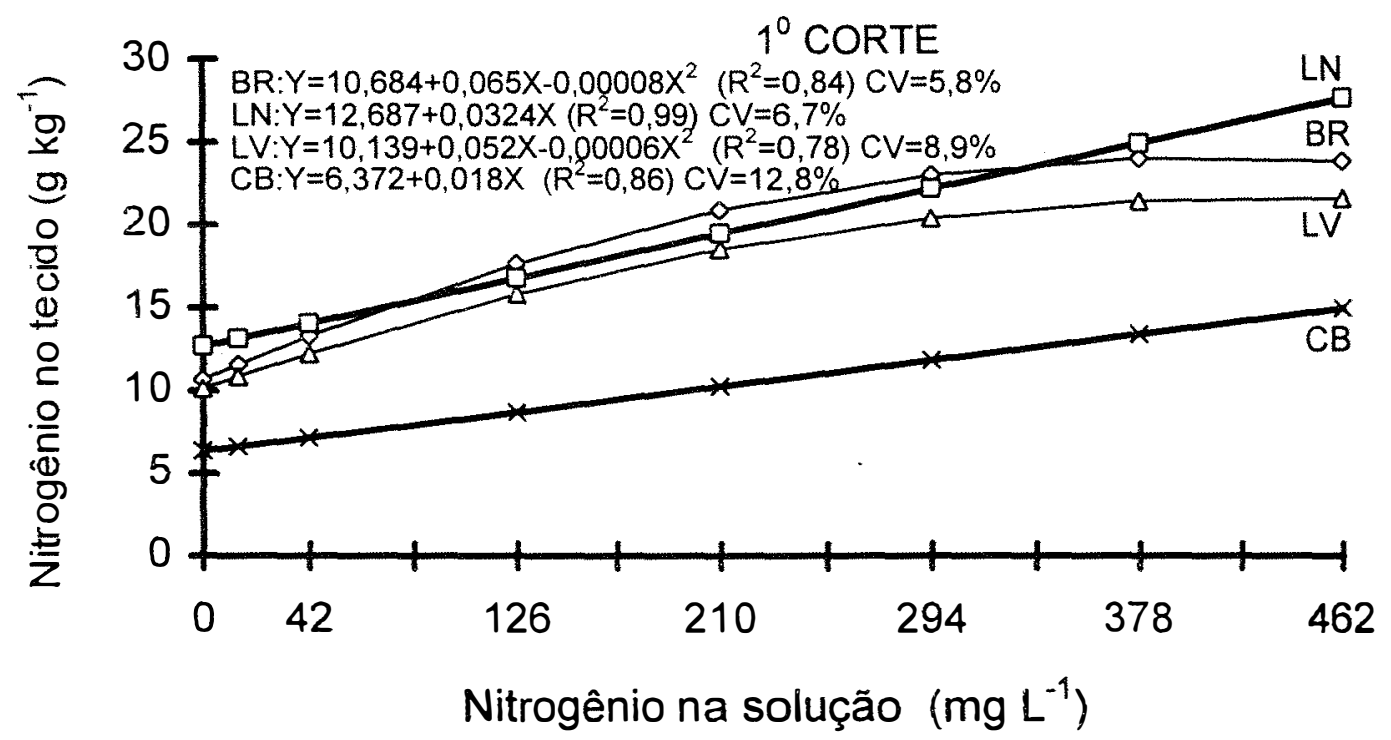

Figura 6 - Concentração de nitrogênio nas partes da parte aérea (folhas nãoexpandidas, BR; lâminas de folhas novas, LN; lâminas de folhas velhas, LV; colmos+bainhas, CB) no primeiro corte da Brachiaria decumbens Stapf., em função das doses de nitrogênio na solução nutritiva. $C V=$ Coeficiente de variação.

No segundo crescimento, a concentração de nitrogênio nos componentes da planta também apresentou efeito significativo $(P<0,01)$ em função das doses de nitrogênio na solução.

$\mathrm{Na}$ Figura 7 verifica-se que a concentração de nitrogênio foi mais baixa nos colmos+bainhas que nas demais partes no segundo crescimento e 
ajustou-se a um modelo linear de regressão. O mais elevado teor obtido na

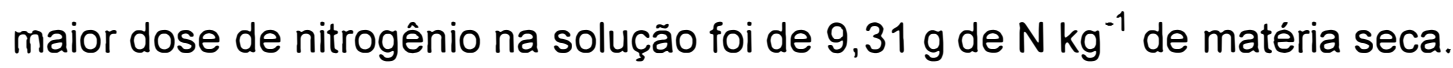

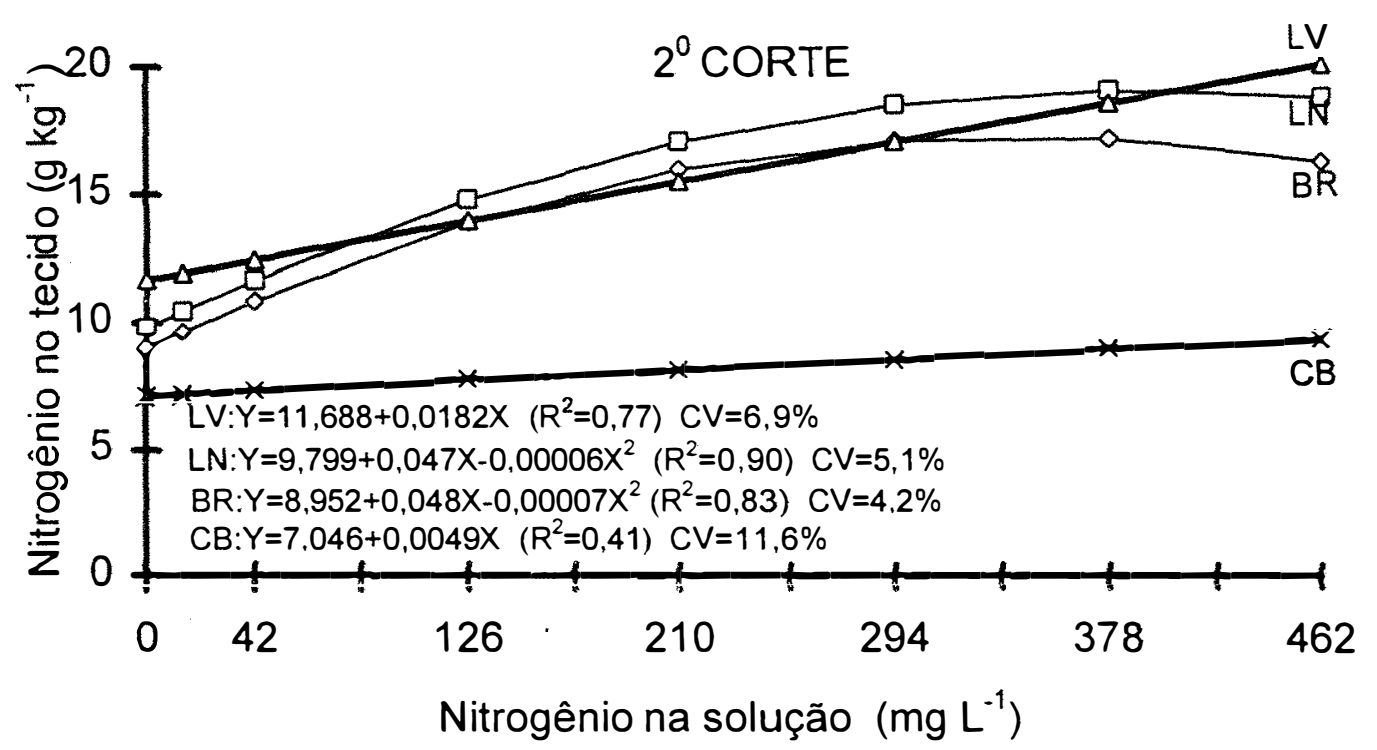

Figura 7 - Concentração de nitrogênio nas partes da planta (folhas nãoexpandidas, BR; lâminas de folhas novas, $L N$; lâminas de folhas velhas, LV; colmos+bainhas, CB) no segundo corte da Brachiaria decumbens Stapf., em função das doses de nitrogênio na solução nutritiva. $\mathrm{CV}=$ Coeficiente de variação.

As folhas velhas também apresentaram comportamento linear, com

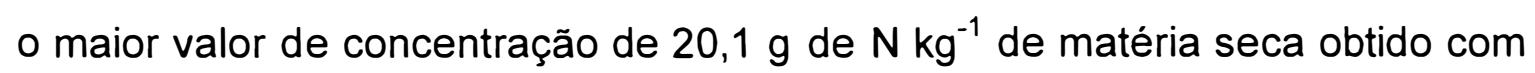
a dose mais elevada de nitrogênio. Entretanto, nas folhas não-expandidas e nas lâminas de folhas novas houve ajuste a um modelo quadrático de regressão, sendo as máximas concentrações de 17,1 e $19,0 \mathrm{~g}$ de $\mathrm{N} \mathrm{kg}^{-1}$ de

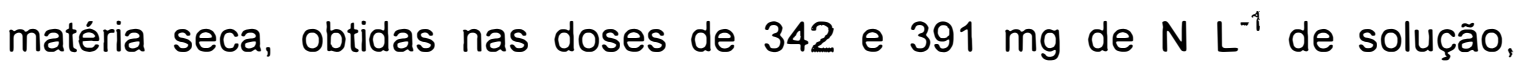
respectivamente.

A concentração de nitrogênio para os componentes da braquiária no primeiro e no segundo crescimento, foi superior aos valores de $12 \mathrm{~g} \mathrm{de} \mathrm{N} \mathrm{kg}^{-1}$ 
reportados para a Brachiaria decumbens e a Brachiaria brizantha obtidos por Bredon \& Horrell (1962) e de 12,6 $\mathrm{g}_{\text {de }} \mathrm{N} \mathrm{kg}^{-1}$ em Brachiaria decumbens obtidos por Oliveira (1980), ambos avaliando a parte aérea total da planta. Essas concentrações de nitrogênio são consideradas baixas.

A concentração de nitrogênio nas lâminas de folhas novas da braquiária foi superior aquela obtida por Corrêa (1996) no capim Tanzânia-1, enquanto que em colmos+bainhas a concentração de nitrogênio foi inferior às observadas com Colonião, Tanzânia-1 e Vencedor, submetidos a doses de nitrogênio em solução nutritiva.

\subsubsection{Concentração de nitrogênio nas raízes}

A concentração de nitrogênio nas raizes do capim-braquiária, em função das doses de nitrogênio apresentou ajuste ao modelo quadrático de regressão, conforme demonstrado na Figura 8.

Através da análise de variância foi demonstrado que houve efeito significativo $(P<0,01)$ das doses de nitrogênio no teor deste nutriente nas raízes da braquiária. De maneira gerail a concentração de nitrogênio nas raízes foi mais baixa que a encontrada nos componentes da parte aérea da forrageira.

Pela equação de regressão apresentada na Figura 8, verifica-se que nas raizes da braquiária a máxima concentração de nitrogênio $\left(10,9 \mathrm{~g} \mathrm{de} \mathrm{N} \mathrm{kg}^{-1}\right.$

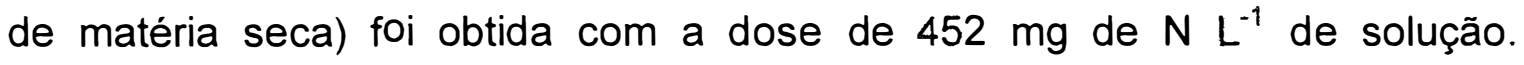
Também, constatou-se que houve um incremento da concentração de nitrogênio na ordem de duas vezes, quando comparadas a mínima ea máxima concentração deste nutriente nas raizes desta forrageira. 


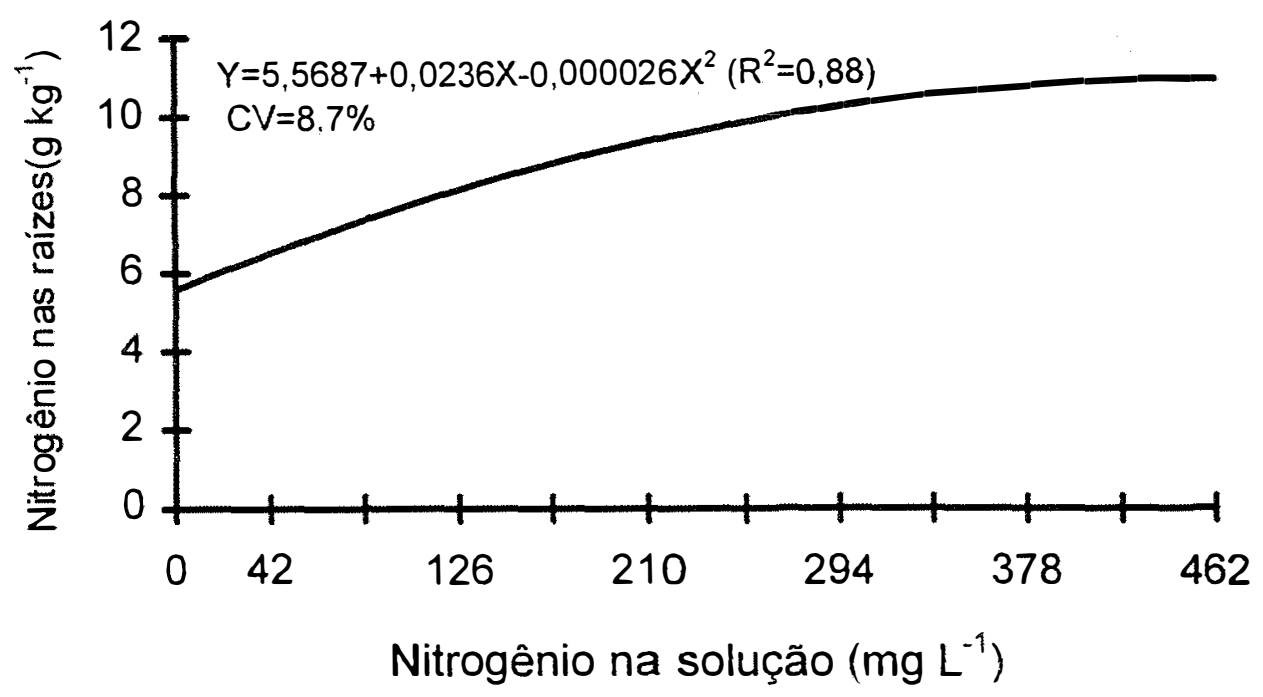

Figura 8 - Concentração de nitrogênio nas raízes da Brachiaria decumbens Stapf., em função das doses de nitrogênio na solução nutritiva. $C V=$ Coeficiente de variação

\subsubsection{Acúmulo de nitrogênio nos componentes da planta}

O acúmulo de nitrogênio no capim-braquiária (Tabela 2) foi obtido multiplicando-se as concentrações deste nutriente em cada componente (folhas não-expandidas, lâminas de folhas novas, lâminas de folhas velhas $e$ colmos+bainhas) e na parte aérea da forrageira pela produção de matéria seca de cada componente e da parte aérea dividindo-se esses produtos por 1000 .

Foi observado efeito significativo $(P<0,01)$ das doses de nitrogênio na solução, sobre a quantidade de nitrogênio acumulado nos componentes e na parte aérea da planta. Na Tabela 2 estão apresentadas as equações de regressão referentes ao acúmulo de nitrogênio nos componentes e na parte aérea no primeiro e segundo crescimentos da forrageira. 
Tabela 2. Equações de regressão referentes ao acúmulo de nitrogênio nos componentes e na parte aérea da Brachiaria decumbens Stapf., no primeiro e segundo crescimento, em função das doses de nitrogênio na solução.

\begin{tabular}{l|cc}
\hline \multicolumn{1}{c}{ Parte da planta } & \multicolumn{1}{c}{ equacão } & $\mathrm{R}^{2}$ \\
\hline & Primeiro cultivo & \\
\hline Folhas não-expandidas & $\mathrm{Y}=-0,0818+0,0112 \mathrm{X}-0,000007 \mathrm{X}^{2}$ & 0,94 \\
Lâminas de folhas novas & $\mathrm{Y}=-0,3868+0,0461 \mathrm{X}$ & 0,99 \\
Lâminas de folhas velhas & $\mathrm{Y}=0,0427+0,0320 \mathrm{X}$ & 0,98 \\
Colmos+bainhas & $\mathrm{Y}=-1,3672+0,0680 \mathrm{X}$ & 0,99 \\
Parte aérea & $\mathrm{Y}=-1,5815+0,1540 \mathrm{X}$ & 0,99 \\
\hline & Segundo cultivo & \\
\hline Folhas não-expandidas & $\mathrm{Y}=0,2800+0,0096 \mathrm{X}$ & 0,92 \\
Lâminas de folhas novas & $\mathrm{Y}=0,2596+0,0554 \mathrm{X}$ & 0,97 \\
Lâminas de folhas velhas & $\mathrm{Y}=0,5866+0,0236 \mathrm{X}$ & 0,93 \\
Colmos+bainhas & $\mathrm{Y}=0,6956+0,0490 \mathrm{X}$ & 0,95 \\
Parte aérea & $\mathrm{Y}=1,8179+0,1377 \mathrm{X}$ & 0,96 \\
\hline
\end{tabular}

A análise dos resultados apresentados através dessas equações indica que só houve efeito quadrático nas folhas não-expandidas no primeiro crescimento, enquanto que nos demais componentes esse efeito foi linear tanto no primeiro como no segundo crescimento da planta. Isso demonstra que esta gramínea forrageira tem potencialidade para acumular ainda mais nitrogênio nos seus componentes que as quantidades acumuladas neste experimento. Ressalta-se que essas plantas foram cultivadas em doses de 0 até $462 \mathrm{mg}$ de 
$\mathrm{N} \mathrm{L}^{-1}$ de solução (valor bem mais elevado que os $210 \mathrm{mg} \mathrm{N} \mathrm{L}^{-1}$ da solução nutritiva de Sarruge, 1975).

$\mathrm{Na}$ Tabela 3 são apresentadas as distribuições porcentuais da quantidade de nitrogênio acumulado no primeiro e segundo crescimentos dos componentes (folhas não-expandidas, lâminas de folhas novas, lâminas de folhas velhas e colmos+bainhas) em relação à parte aérea da forrageira.

Pode-se observar que, no primeiro crescimento, nas folhas nãoexpandidas o acúmulo de nitrogênio foi menor que nas demais partes e foi decrescente com $\circ$ aumento da concentração deste elemento até a dose126 $\mathrm{mg}$ de $\mathrm{N} \mathrm{L}^{-1}$. Contudo, o maior acúmulo deste nutriente ocorreu nos colmos+bainhas sendo crescente com o aumento das doses de nitrogênio na solução até a dose $126 \mathrm{mg}$ de $\mathrm{N} \mathrm{L}^{-1}$. Em relação às lâminas de folhas novas, foi observado um menor acúmulo de nitrogênio até a dose $210 \mathrm{~g} \mathrm{~L}^{-1}$ de solução, de 36 até $27 \%$ do total na parte aérea. A partir daí essa porcentagem ficou estável em 29 e $31 \%$.

Por outro lado, verificou-se que nas lâminas de folhas velhas o acúmulo de nitrogênio foi inferior à quantidade acumulada nas lâminas de folhas novas e nos colmostbainhas, para cada dose de nitrogênio. Essa distribuição do nitrogênio acumulado deve-se principalmente à alta mobilidade deste nutriente, que se redistribui no floema para suprir as folhas mais novas (Mengel \& Kirkby, 1987; Marschner, 1995).

No segundo crescimento $o$ acúmulo de nitrogênio também foi menor nas folhas não-expandidas que nas demais partes, porém não houve redução dessa distribuição porcentual com o aumento das doses de nitrogênio. As lâminas de folhas velhas apresentaram menor acúmulo de nitrogênio em relação a lâminas de folhas novas e a colmos+bainhas em função das doses de nitrogênio na solução. Nos colmos+bainhas observou-se que o nitrogênio acumulado aumentou até a dose de $210 \mathrm{mg}$ de $\mathrm{N} \mathrm{L}^{-1}$ de solução. 
Tabela 3. Valores porcentuais (\%) da distribuição de nitrogênio nos componentes da Brachiaria decumbens Stapf. em relação ao nitrogênio acumulado na parte aérea $(P A=100)$ nos dois períodos de crescimento em função das doses de nitrogênio na solução.

\begin{tabular}{c|c|c|c|c|c|c|c|c}
\hline \multirow{2}{*}{$\begin{array}{c}\text { N } \\
\mathrm{mg} \mathrm{L}^{-1}\end{array}$} & \multicolumn{5}{|c|}{ Primeiro corte } & \multicolumn{3}{c}{ Segundo corte } \\
\cline { 2 - 8 } & BR & LN & LV & C+B & BR & LN & LV & C+B \\
\hline 0 & $\star$ & $\star$ & $\star$ & $\star$ & $\star$ & $\star$ & $\star$ & * \\
14 & 11 & 36 & 28 & 25 & 7 & 36 & 20 & 37 \\
42 & 8 & 33 & 25 & 34 & 8 & 36 & 19 & 37 \\
126 & 6 & 33 & 21 & 40 & 7 & 38 & 17 & 38 \\
210 & 5 & 27 & 27 & 41 & 7 & 36 & 17 & 40 \\
294 & 7 & 29 & 22 & 42 & 9 & 38 & 19 & 34 \\
378 & 6 & 31 & 21 & 42 & 8 & 41 & 18 & 33 \\
462 & 5 & 30 & 21 & 44 & 6 & 40 & 17 & 37 \\
\hline
\end{tabular}

Folhas não-expandidas=BR; Lâminas de folhas novas=LN; Lâminas de folhas velhas $=\mathrm{LV}$; Colmos+bainhas $=\mathrm{C}+\mathrm{B}$

* Não houve material vegetal suficiente para análise

\subsubsection{Nível crítico de nitrogênio no capim-braquiária}

No primeiro crescimento do capim-braquiária foi observado que houve relação significatiâ $(P<0,01)$ das concentrações de nitrogênio apenas nos componentes lâminas de folhas novas e folhas não-expandidas quanto a produção de matéria seca da parte aérea. No segundo crescimento a significância foi constatada nos componentes lâminas de folhas novas, folhas não-expandidas e parte aérea. As lâminas de folhas novas foram, entre os 
componentes da planta, os que expressaram os mais altos coeficientes para essa correlação.

Nos dois crescimentos da forrageira foram determinados os coeficientes de correlação entre as concentrações de nitrogênio nos componentes da parte aérea e a produção de matéria seca da parte aérea. No primeiro crescimento obteve-se para folhas não-expandidas $r=0,81$; lâminas de folhas novas $r=0,94$; lâminas de folhas velhas $r=0,74$ e colmos+bainhas $r=0,82$ e da parte aérea toda $r=0,84$. No segundo crescimento obteve-se para folhas não-expandidas $r=0,88$; lâminas de folhas novas $r=0,93$; lâminas de folhas velhas $r=0,82$ e colmos + bainhas $r=0,47$ e da parte aérea $r=0,84$. Considerando esses resultados para essas relações, pode-se estabelecer que, entre os componentes da forrageira, a amostragem das lâminas de folhas novas é indicada para a avaliação do estado nutricional em nitrogênio no capimbraquiária (Figura 9).

Neste estudo adotou-se o conceito de nivel crítico definido por Ulrich \& Hills (1973), que corresponde à obtenção desse nivel através da concentração do nutriente que corresponde a $90 \%$ da produção ótima da cultura.

Os valores de nivel crítico de nitrogênio obtidos na amostragem de lâminas de folhas novas foram de $22,0 \mathrm{~g}_{\text {de }} \mathrm{N} \mathrm{kg}^{-1}$ no primeiro crescimento e de $14,5 \mathrm{~g}$ de $\mathrm{N} \mathrm{kg}^{-1}$ no segundo crescimento (Figura 9).

A utilização desta parte da planta para avaliação do estado nutricional em nitrogênio é importante não apenas pela facilidade de amostragem do material, como também pela maior estabilidade dos resultados em relação à amostragem em que se recolhe toda a parte aérea. Neste caso, a comprovada variação das concentrações nos demais componentes, como demonstrado nas figuras 6 e 7, poderá exercer influência significativa no valor do nivel crítico, uma vez que a parte da planta que for amostrada em maior 
quantidade certamente influenciará no resultado da análise. Por isso é preciso maior rigor na coleta do material vegetal quando a parte aérea for amostrada para determinação do teor de nitrogênio na forrageira.

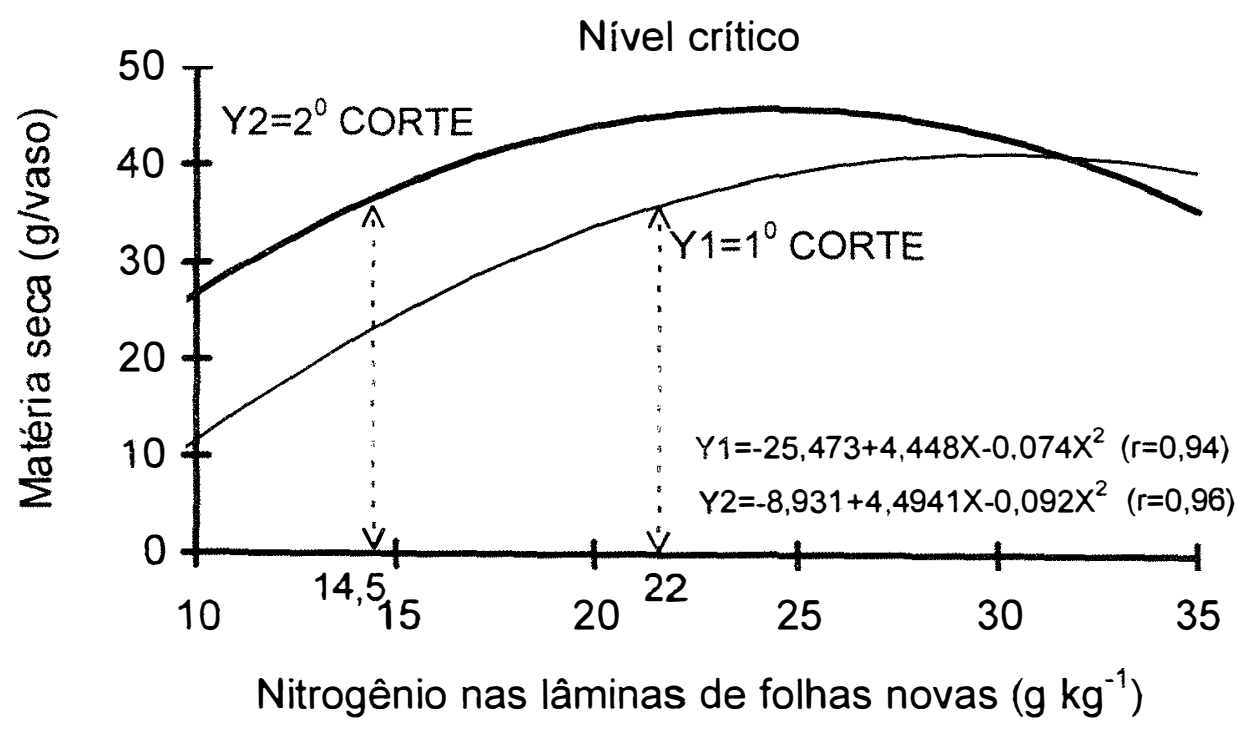

Figura 9 - Relação entre a concentração de nitrogênio nas lâminas de folhas novas no primeiro e segundo cortes e a produção de matéria seca da parte aérea nos respectivos cortes da Brachiaria decumbens Stapf.

\subsubsection{Relação do teor de N e valor SPAD no capim-braquiária}

Na Figura 10 estão demonstradas as equações e os valores SPAD medidos nas lâminas de folhas novas em função da concentração de nitrogênio nas lâminas de folhas novas nos dois crescimentos do capim-braquiária. 


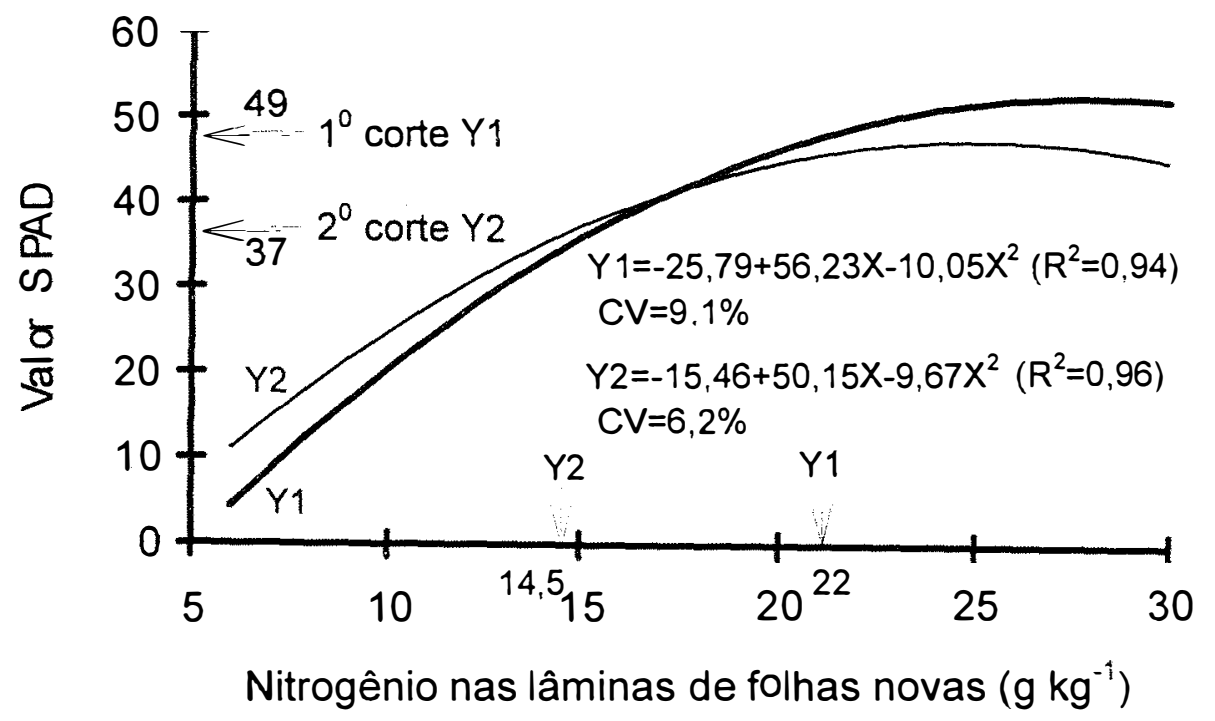

Figura 10 - Relação entre a concentração de nitrogênio nas lâminas de folhas novas no primeiro e segundo cortes com o valor SPAD medido nas lâminas de folhas novas dos respectivos cortes da Brachiaria decumbens Stapf. $\mathrm{CV}=$ Coeficiente de variação.

Verificou-se relação significativa $(P<0,01)$ das concentrações de nitrogênio nas lâminas de folhas novas, sobre valores SPAD observados em ambos os crescimentos do capim-braquiária. $O$ estudo de regressão demonstrou que, entre os componentes da planta, lâminas de folhas novas foi o que apresentou os mais altos coeficientes de correlação com os valores SPAD, sendo de 0,94 no primeiro e de 0,96 no segundo crescimento da forrageira.

Obtive-se no primeiro crescimento o nivel crítico em valor SPAD de 49 e no segundo crescimento o valor SPAD de 37 no capim-braquiária, que corresponderam à 22 e $14,5 \mathrm{~g}_{\text {de }} \mathrm{N} \mathrm{kg}^{-1}$ de matéria seca nas lâminas de folhas novas, respectivamente. Esses resultados indicam a viabilidade de uso do 
clorofilômetro para estimar a concentração de nitrogênio e, consequentemente, predizer a necessidade de fertilização nitrogenada no capim-braquiária.

\subsubsection{Sintomatologia de deficiência de nitrogênio}

A sintomatologia visual na braquiária em função das doses de nitrogênio começou a ser expressada após duas semanas do transplante das mudas. No primeiro crescimento foi verificado que, em condições da omissão (doses 0) de nitrogênio, as plantas não cresceram e emitiram apenas três pequenas folhas que ficaram totalmente cloróticas e com os bordos laminares necrosados. $O$ aparecimento de sintomas de deficiência se deu até na dose de $126 \mathrm{mg}$ de $\mathrm{N} \mathrm{L}^{-1}$ de solução.

Notadamente, no segundo crescimento os sintomas foram mais pronunciados e afetaram com maior rigor a rebrota das plantas submetidas às doses mais baixas de nitrogênio. Nestas condições, foi observado inicialmente que as folhas mais velhas apresentaram clorose intensa, seguidas das folhas mais novas e das folhas não-expandidas. Além disso, constatou-se que a senescência de folhas foi mais precoce que nos tratamentos com doses acima de $210 \mathrm{mg}$ de $\mathrm{N} \mathrm{L}^{-1}$ de solução. Essas observações são semelhantes às de Santos et al. (1995) em capim-vencedor.

O crescimento das plantas e o número de perfilhos foram visivelmente limitados nas condições de deficiência de nitrogênio. Os sintomas visuais de deficiência de nitrogênio em braquiária observados neste estudo, confirmam as citações de vários autores (Mengel \& Kirkby, 1987; Marschner, 1995; Malavolta, 1997) como características gerais deste elemento sobre as plantas. 


\subsection{Conclusões}

Nas condições em que foi desenvolvido o experimento, os resultados permitem apresentar as seguintes conclusões:

- O aumento das doses de nitrogênio em solução proporcionou aumentos na produção de matéria seca na parte aérea, nas raízes e no número de perfilhos do capim-braquiária.

- O nitrogênio estimulou a atividade da redutase do nitrato. $O$ teor de clorofila nas folhas da braquiária apresentou alta correlação com as doses de nitrogênio adicionadas.

- Os colmos+bainhas apresentaram as mais baixas concentrações de nitrogênio que outros componentes da parte aérea, em função das doses desse nutriente na soiução. $O$ acúmulo de nitrogênio foi menor nas folhas nãoexpandidas e maior nos colmos+bainhas no primeiro crescimento e nas lâminas de folhas novas no segundo crescimento da forrageira.

- As lâminas de folhas novas apresentaram as melhores correlações da produção de matéria seca da parte aérea tanto com teor de nitrogênio como com teor de clorofila. devendo ser, portanto, o componente utilizado para avaliação do estado nutricional em nitrogênio no capim-braquiária. O nivel crítico desse nutriente está entre 14,5 e $22,0 \mathrm{~g}_{\text {de }} \mathrm{N} \mathrm{kg}^{-1}$ de matéria seca, 0 qual corresponde a valor SPAD entre 37 e 49, respectivamente. 


\section{DIAGNOSE NUTRICIONAL E RESPOSTAS DO CAPIM- BRAQUIÁRIA SUBMETIDO A DOSES DE ENXOFRE}

\subsection{Resumo}

O experimento foi realizado em casa-de-vegetação, no período de outubro a dezembro de 1996, com Brachiaria decumbens Stapf. cv. Basilisk cultivada em solução nutritiva e utilizando sílica como substrato. Foi empregado o delineamento de blocos completos ao acaso com quatro repetições. $O$ primeiro corte das plantas foi realizado aos 40 dias do transplante para os vasos e o segundo 30 dias depois do primeiro. Foram avaliadas oito doses de enxofre $\left(0 ; 2 ; 4 ; 16 ; 32 ; 48 ; 64\right.$ e $\left.80 \mathrm{mg} \mathrm{L}^{-1}\right)$ na produção de matéria seca, no número de perfilhos, na atividade da redutase do nitrato, no teor de clorofila $e$ na concentração e no acúmulo de enxofre na planta. As doses de enxofre proporcionaram aumentos na produção de matéria seca da parte aérea em ambos os cortes e das raízes da braquiária e influenciaram no número de perfilhos no segundo crescimento dessa forrageira. $A$ atividade da redutase do nitrato e $o$ teor de clorofila foram influenciados pelas doses de enxofre. Comparando-se as partes amostradas a concentração de enxofre foi mais baixa nos colmos+bainhas nas doses mais baixas e nas lâminas de folhas novas nas doses mais altas de enxofre na solução, no primeiro crescimento. $O$ acúmulo de enxofre foi menor nas folhas não-expandidas e maior nos colmos+bainhas. As lâminas de folhas novas mostraram-se as mais indicadas para a avaliação da nutrição em enxofre no capim Brachiaria decumbens. $O$ nivel crítico de enxofre no capim-braquiária foi de 0,81 e $1,0 \mathrm{~g} \mathrm{de}^{\mathrm{sg}} \mathrm{kg}^{-1} \mathrm{de}$ matéria seca. 


\subsection{Summary: NUTRIENT DIAGNOSIS AND RESPONSES OF Brachiaria decumbens Stapf TO SULFUR RATES}

An experiment was carried out in greenhouse conditions from October to December of 1996, with Brachiaria decumbens Stapf. cv. Basilisk. Plants were grown in nutrient solution and ground quartz was used as substrate. A complete randomized block design was used, with four replications. Plants were harvested 40 days after transplanting the seedlings to the pots and 30 days after the first harvest. Eight rates of sulfur were studied $(0 ; 2 ; 4 ; 16 ; 32$; 48; 64 and $80 \mathrm{mg} \mathrm{L}^{-1}$ ) and dry matter yield, tiller number, nitrate reductase activity, chlorophyll concentration and concentration and content of sulfur in the plant were determined. Sulfur rates provided increases on dry matter yield of plant tops in both harvest and roots and in tiller number in second harvest. Nitrate reductase activity and chlorophyll concentration were increased with sulfur rates. Sulfur concentration in plant was lower in stems+sheaths for the lower rates and it was lower in the young leaf blades in the highest sulfur rates. Sulfur content was lower in the non-expanded leaves and higher in the stems+sheaths, in both harvests of the forage. The young leaf blades are recommended for evaluating the nutritional status of sulfur in Brachiaria decumbens, and the sulfur critical level was in the range of 0.81 to $1.00 \mathrm{~g} \mathrm{~S} \mathrm{~kg}^{-1}$ dry matter.

\subsection{Introdução}

A exploração racional das pastagens é fundamental para aumentar a disponibilidade de forragem e melhorar a qualidade da alimentação dos herbivoros. A Brachiaria decumbens Stapf., comumente denominada capim- 
braquiária, é bastante difundida nas regiões brasileiras e apresenta boa adaptação principalmente nas áreas de Cerrado, as quais se caracterizam pela relativa acidez e baixa fertilidade dos solos. Carvalho et al. (1991) relataram que as pastagens formadas com essa forrageira têm apresentado redução gradativa de produtividade após seu estabelecimento. Também Soares Filho et al. (1992) relataram que a maioria das pastagens com capim-braquiária, no Estado de São Paulo, vem apresentando queda de produção no decorrer dos subsequentes ciclos de pastejo. Estima-se que pastagens de braquiárias ocupem mais de 40 milhões de hectares no Brasil e a Brachiaria decumbens Stapf., junto com a Brachiaria brizantha cv. Marandu, representam mais de 85 $\%$ dessa área (Valle \& Miles, 1994).

A maior utilização de adubos concentrados nos anos recentes vem reduzindo significativamente a adição de enxofre em áreas de cultivo, com efeitos mais agravantes em solos de textura mais arenosa, com baixos teores de matéria orgânica e em áreas com alta incidência pluvial. Ressalta-se também que a percolação de água no perfil do solo favorece a lixiviação do sulfato e que áreas submetidas a queimadas periódicas facilitam a volatilização do enxofre (Malavolta et al., 1974; Vitti \& Novais, 1986). Esse nutriente é constituinte dos aminoácidos cistina, cisteína e metionina os quais contém cerca de $90 \%$ do total de enxofre na planta. Em condições de baixa disponibilidade desse nutriente, tem-se constatado limitação na produção de matéria seca de forrageiras.

Segundo Shirley \& Mariante (1976), o teor de enxofre na faixa de 1,0 a $2,0 \mathrm{~g}_{\text {de }} \mathrm{S} \mathrm{kg}^{-1}$ de matéria seca na forrageira é recomendado para dietas de bovinos e ovinos. Gallo et al. (1974) relataram que, tomando-se por base o teor de $1,0 \mathrm{~g}$ de $\mathrm{S} \mathrm{kg}^{-1}$ de matéria seca, apenas $30 \%$ dos capins e $52 \%$ das leguminosas no pasto se situaram dentro ou acima desse nível, em amostragem de forrageiras no Estado de São Paulo. No capim-braquiária esses 
autores obtiveram teor médio de $0,14 \%$ de enxofre.

Souza (1986) mencionou que estudos realizados no CIAT mostraram respostas diferenciadas na produção de matéria seca das forrageiras à dose de até $30 \mathrm{~kg}$ de $S$ ha $^{-1}$ durante três cortes. Os capins colonião e braquiária foram responsivos ao enxofre quanto a produção de matéria seca até a dose de $20 \mathrm{~kg} \mathrm{ha}^{-1}$, sendo o capim-braquiária o mais eficiente.

Marques et al. (1995) relataram que a omissão de enxofre não influenciou o perfilhamento e nem o rendimento total de matéria seca da parte aérea dos capins braquiarão e andropogon cultivados em Cambissolo álico. Em estudo com solução nutritiva. Monteiro et al. (1995) verificaram significativas reduções na produção de matéria seca e no número de perfilhos do capimMarandu no tratamento em que se omitiu enxofre quando comparado ao tratamento completo.

Os objetivos deste estudo foram de avaliar respostas da Brachiaria decumbens Stapf cv. Basilisk quanto a produção de matéria seca, ao perfilhamento, à atividade enzimática, ao teor de clorofila, o nível crítico de enxofre e à concentração e acúmulo desse nutriente nos componentes e na parte aérea, quando submetida a doses de enxofre em solução nutritiva.

\subsection{Material e métodos}

\subsubsection{Localização e espécie forrageira}

O experimento foi realizado no período de outubro a dezembro de 1996, em casa-de-vegetação localizada no Setor de Nutrição Mineral de Plantas, do Departamento de Química da Escola Superior de Agricultura "Luiz de Queiroz"-USP, Piracicaba, São Paulo. Foi utilizada a espécie forrageira Brachiaria decumbens Stapf cv. Basilisk e oito doses de enxofre em solução nutritiva. 


\subsubsection{Doses de enxofre, soluções nutritivas e delineamento experimental}

Foram utilizadas oito doses de enxofre correspondentes a: $0,2,4$, $16,32,48,64$ e $80 \mathrm{mg}$ de $S L^{-1}$ de solução nutritiva. As soluções foram preparadas a partir da solução de Sarruge (1975), devidamente modificada para as oito doses de enxofre propostas. O preparo das soluções para atender às doses de enxofre se deu conforme demonstrado na tabela 4 .

Tabela 4 - Volumes ( $m L^{-1}$ ) das soluções estoques empregados no preparo das soluções nutritivas para as doses de enxofre $\left(\mathrm{mg} \mathrm{L}^{-1}\right)$ estudadas.

\begin{tabular}{|c|c|c|c|c|c|c|c|c|}
\hline \multirow{2}{*}{$\begin{array}{l}\text { Soluções } \\
\text { estoque }\end{array}$} & \multicolumn{8}{|c|}{ Doses de enxofre $\left(\mathrm{mg} \mathrm{L}^{-1}\right)$} \\
\hline & 0 & 2 & 4 & 16 & 32 & 48 & 64 & 80 \\
\hline $\mathrm{MgSO}_{4} \quad \mathrm{M}$ & - & 0,06 & 0,12 & 0,5 & 1 & 1,5 & 2 & 2 \\
\hline$\left(\mathrm{NH}_{4}\right)_{2} \mathrm{SO}_{4} \mathrm{M}$ & - & - & - & - & - & - & - & 0,5 \\
\hline $\mathrm{KH}_{2} \mathrm{PO}_{4}$ & - & 1 & 1 & 1 & 1 & 1 & 1 & 1 \\
\hline $\mathrm{KCl}$ & 6 & - & - & - & - & - & - & - \\
\hline $\mathrm{KNO}_{3}$ & - & 5 & 5 & 5 & 5 & 5 & 5 & 5 \\
\hline $\mathrm{Ca}\left(\mathrm{NO}_{3}\right)_{2} \quad \mathrm{M}$ & 5 & 3,06 & 3,12 & 3,5 & 4 & 4,5 & 5 & 4,5 \\
\hline $\mathrm{CaCl}_{2}$ & - & 2,19 & 1,87 & 1,5 & 1 & 0,5 & & 0,5 \\
\hline $\mathrm{NH}_{4} \mathrm{H}_{2} \mathrm{PO}_{4} \quad \mathrm{M}$ & 1 & - & - & - & - & - & - & - \\
\hline $\mathrm{Mg}\left(\mathrm{NO}_{3}\right)_{2} \quad \mathrm{M}$ & 2 & 1,94 & 1,87 & 1,5 & 1 & 0,5 & - & - \\
\hline Micro $-\mathrm{Fe}$ * & 1 & 1 & 1 & 1 & 1 & 1 & 1 & 1 \\
\hline Fe-EDTA $\quad * *$ & 1 & 1 & 1 & 1 & 1 & 1 & 1 & 1 \\
\hline
\end{tabular}

* $A$ solução de micronutrientes teve a seguinte composição $\left(\mathrm{g} \mathrm{L}^{-1}\right): \mathrm{H}_{3} \mathrm{BO}_{3}, 2,86$; $\mathrm{MnCl}_{2} \cdot 4 \mathrm{H}_{2} \mathrm{O}, 1,81 ; \mathrm{ZnCl}_{2}, 0,10 ; \mathrm{CuCl}_{2}, 0,04$ e $\mathrm{H}_{2} \mathrm{MoO}_{4} \cdot \mathrm{H}_{2} \mathrm{O}, 0,02$.

**Dissolveram-se $26,1 \mathrm{~g}$ de EDTA dissódico em $286 \mathrm{~mL}$ de $\mathrm{NaOH} \mathrm{N}$, misturando-se com $24,0 \mathrm{~g}$ de $\mathrm{FeSO}_{4} .7 \mathrm{H}_{2} \mathrm{O}$, arejando-se por uma noite e completando-se a 1 litro de água deionizada. 
Foi empregado o delineamento experimental de blocos completos ao acaso, com oito doses de enxofre e quatro repetições. Prevendo-se assegurar a produção de material vegetal suficiente para a execução das análises químicas das partes da planta, principalmente nos tratamentos com baixas doses de enxofre em solução, tratou-se de duplicar cada uma das repetições dos vasos do experimento. Assim sendo foram empregados 64 vasos neste estudo.

\subsubsection{Instalação e condução do experimento}

As sementes de braquiária foram germinadas em bandejas plásticas, contendo areia lavada em água corrente e posteriormente em água deionizada. Vasos plásticos com capacidade para 3,6 litros foram preenchidos com sílica com diâmetro em torno de $3 \mathrm{~mm}$, que também foi lavada até retirada das impurezas.

Após 14 dias da semeadura, 15 mudas das plantas com cerca de 5 $\mathrm{cm}$ de altura foram transplantadas para cada vaso e foi adicionado um litro de solução diluída a $30 \%$ da concentração total correspondente a cada dose de enxofre. Inicialmente as soluções permaneceram nos vasos durante o dia e a noite, sendo circulada através da sílica três vezes ao dia por um período de três dias. Posteriormente, a solução foi drenada à noite e durante esta fase foram realizados desbastes periódicos até permanecerem cinco plantas por vaso. Após oito dias do transplante, as soluções com concentração definitiva foram adicionadas aos vasos e foram trocadas a cada 14 dias. Durante o período experimental, a temperatura ambiente variou entre 22 a $34{ }^{\circ} \mathrm{C}$ e a cada três dias, os vasos eram remanejados dentro de cada bloco, para que houvesse menor efeito das condições ambientais. 
Aos 40 dias após o transplante procedeu-se ao primeiro corte a uma altura de $2 \mathrm{~cm}$ do colo das raízes e as plantas foram separadas em folhas nãoexpandidas, lâminas de folhas novas (lâminas das duas folhas superiores totalmente expandidas), lâminas de folhas velhas (lâminas das demais folhas) e colmos+bainhas (colmo propriamente dito mais as bainhas que foram mantidas a eles circundadas). As folhas foram consideradas totalmente expandidas quando apresentavam a lígula visível.

O segundo corte foi efetuado no colo das raizes, 30 dias após o primeiro e as plantas foram separadas segundo o mesmo critério, sendo que as raizes também foram separadas e lavadas. O material vegetal foi colocado para secar em estufa de circulação de ar, à temperatura de $65^{\circ} \mathrm{C}$, durante 72 horas.

\subsubsection{Produção de matéria seca}

A produção de matéria seca de cada componente da parte aérea (folhas não expandidas, lâminas de folhas novas, lâminas de folhas velhas e colmos+bainhas) e das raízes foi obtida através de pesagens do material vegetal após a secagem em estufa. A produção da parte aérea foi obtida pela soma dos valores relativos a folhas não-expandidas, lâminas de folhas novas, lâminas de folhas velhas e colmos+bainhas. As amostras foram moídas em moinho de estrutura laminar inox tipo Wiley e acondicionadas em sacos plásticos.

\subsubsection{Análises químicas}

Para obtenção do material vegetal juntaram-se as amostras colhidas nos vasos em duplicata. A determinação da concentração de enxofre em cada 
componente da parte aérea e nas raízes foi executada conforme metodologia de Sarruge \& Haag (1974). A digestão utilizada para a obtenção do extrato foi a nítrico- perclórica e o método analítico empregado foi por turbidimetria do sulfato de bário. O nitrogênio total foi determinado através da digestão sulfúrica com destilação em aparelho semi-micro Kjeldahl e a titulação com ácido sulfúrico.

A atividade da redutase do nitrato foi determinada utilizando-se a metodologia descrita por Mulder et al. (1959). Aos 28 dias no primeiro e 27 dias no segundo crescimento das plantas foram coletadas amostras do limbo foliar da segunda folha completamente expandida (no sentido do ápice para a base). Antes da coleta das folhas, as plantas foram submetidas a duas horas de exposição à luz em temperatura constante de $28{ }^{\circ} \mathrm{C}$ dentro de uma câmara-decrescimento, para redução das variações de fatores ambientais na atividade enzimática. As leituras dos extratos foram realizadas em colorímetro a $540 \mathrm{~nm}$, utilizando-se reta padrão de nitrito e análise de regressão para cálculos da concentração de $\mathrm{NO}_{2}$ no meio.

Utilizou-se o Chlorophyll Meter SPAD-502, (Soil-Plant Analysis Development (SPAD) Section, Minolta Camera Co., Osaka, Japan) para a determinação de valores de clorofila em unidades SPAD em folhas intactas. correspondente à quantidade de clorofila presente na amostra foliar. Os espectros de absorção são calculados com base na quantidade de luz transmitida pela folha amostrada em dois comprimentos de onda, nas áreas do vermelho, aproximadamente em $650 \mathrm{~nm}$, e em infravermelho, em $940 \mathrm{~nm}$, onde os picos de absorção são máximo e mínimo, respectivamente. Nesta faixa, as leituras não são influenciadas pela presença de outros pigmentos, como o caroteno. A luz transmitida é convertida em sinais elétricos, que são digitalizados e microprocessados para cálculo do valor SPAD (Minolta Câmera Co., 1989). 
As leituras do clorofilômetro ocorreram aos 27 dias no primeiro e 26 dias no segundo crescimento das plantas e foram realizadas no terço médio da lâmina da segunda folha completamente expandida a partir do ápice de cada planta. Este procedimento baseou-se em avaliação prévia dos valores de clorofila em unidades SPAD, feita ao longo do comprimento do limbo foliar e em cada folha da planta. Esses resultados preliminares demonstraram que a parte mediana das folhas (terço médio foliar) apresentou maior estabilidade dos valores SPAD, uma vez que no terço basal e na extremidade das folhas foram observadas maiores variações nos resultados. Considerou-se como valor representativo de cada dose de enxofre a média de 10 leituras por vaso tomadas na lâmina foliar das plantas das respectivas doses de enxofre.

\subsubsection{Análises estatísticas}

Os resultados foram submetidos à análise estatística de variância e em função do nível de significância no teste $F$ para doses de enxofre, procedeu-se ao estudo de regressão polinomial ou teste de médias (Tukey $5 \%$ ), utilizando-se o programa estatístico SAS (1989).

\subsection{Resultados e discussão}

\subsubsection{Produção de matéria seca}

A análise de variância mostrou significância $(P<0,01)$ do efeito das doses de enxofre em solução sobre a produção de matéria seca da parte aérea e das raízes tanto no primeiro como no segundo crescimento do capim Brachiaria decumbens Stapf. (Figura 11). 


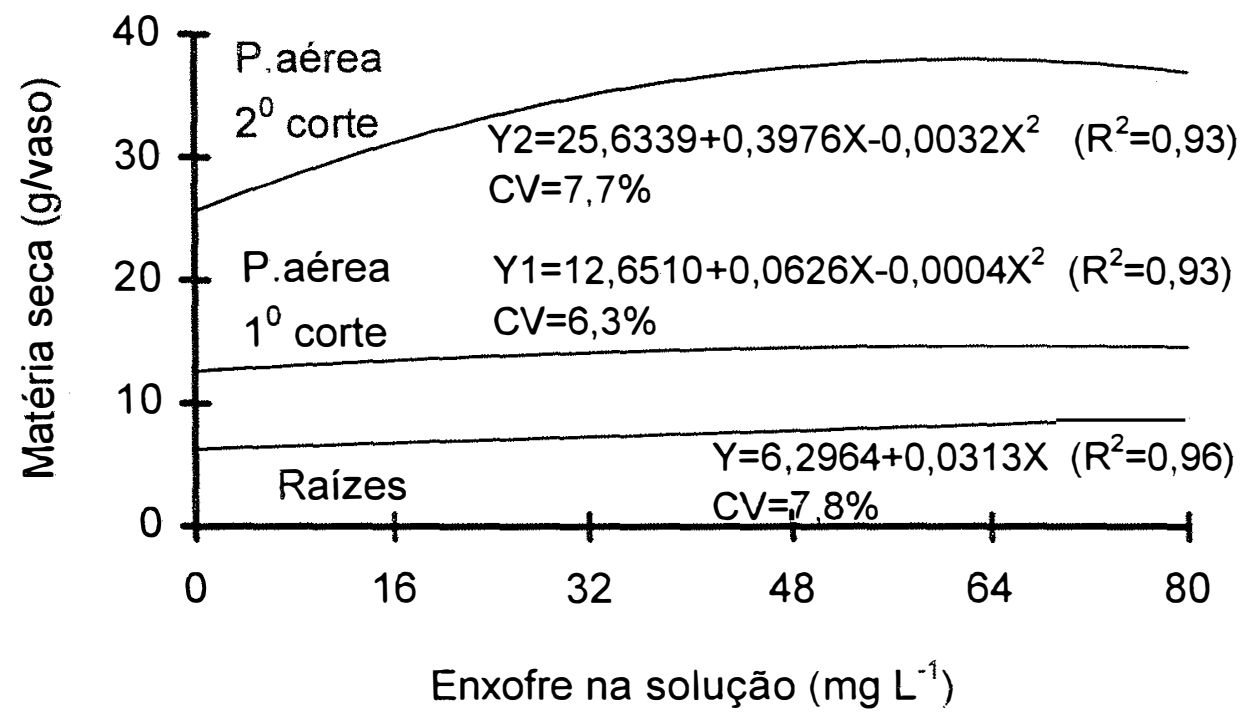

Figura 11 - Produção de matéria seca da parte aérea e das raízes da Brachiaria decumbens Stapf., no primeiro e segundo cortes em função das doses de enxofre. CV=Coeficiente de variação.

A produção da parte aérea da braquiária, nos dois crescimentos, mostrou ajuste a modelo de segundo grau, enquanto as raízes ajustaram-se a modelo linear. No primeiro crescimento a forrageira apresentou um incremento na produção de matéria seca da parte aérea de 19\%, considerando a produção desde condições de omissão do nutriente até a máxima produção. Comparativamente, verificou-se que no primeiro crescimento da planta a produção de matéria seca foi inferior ao crescimento subsequente para todas as doses de enxofre estudadas. No segundo crescimento foi observado que a produção de matéria seca apresentou um incremento de $48 \%$ para as mesmas condições avaliadas no primeiro cultivo. Esta diferença entre as produções que foi 2,5 vezes maior no último cultivo, pode ser atribuída à existência de um maior volume de raízes que pode ter favorecido uma maior absorção de nutrientes e, naturalmente, um maior desenvolvimento vegetativo da forrageira. Além disso, neste período a forrageira já se encontrava estabelecida. Também, 
deve-se considerar a diferença entre as alturas nos dois cortes efetuados na forrageira.

Através das equações de regressão apresentadas na Figura 11, obteve-se que as doses de enxofre de 78 e $62 \mathrm{mg} \mathrm{L}^{-1}$ foram as que proporcionaram as máximas produções de matéria seca da parte aérea no primeiro e no segundo corte da forrageira, respectivamente. Vale ressaltar que a máxima produção de matéria seca no primeiro crescimento representou apenas $40 \%$ da obtida por ocasião do segundo corte. Os resultados deste estudo estão próximos daqueles obtidos em estudo com solo por Hoffmann (1992), que foi de $76 \mathrm{mg}$ de $S \mathrm{~kg}^{-1}$, e por Faquin et al. (1995) que foi de $65 \mathrm{mg}$ de $S \mathrm{~kg}^{-1}$ para Brachiaria decumbens e de $72 \mathrm{mg}$ de $S \mathrm{~kg}^{-1}$ para capimcolonião.

Foi observado (Figura 11) que houve um incremento de produção de matéria seca das raizes da ordem de $39 \%$, entre a dose 0 e a de $80 \mathrm{mg}$ de $\mathrm{S}$ $\mathrm{L}^{-1}$. A resposta linear apresentada pelo sistema radicular às doses de enxofre indica que a braquiária pode produzir mais massa de raizes a valores mais elevados de enxofre em solução que os utilizados neste estudo. Este efeito de linearidade na produção de matéria seca das raízes deve ser considerado como informação relevante para a definição de um programa de manejo mais adequado para esta braquiária quanto ao uso de fertilizantes contendo enxofre.

Monteiro \& Ono (1995) também obtiveram respostas significativas $(P<0,01)$ na produção de matéria seca de raizes de Brachiaria brizantha, em função da aplicação de enxofre em solução.

A Figura 12 apresenta ilustração do efeito das doses de enxofre no desenvolvimento da parte aérea (a) e das raizes (b) de Brachiaria decumbens Stapf. 

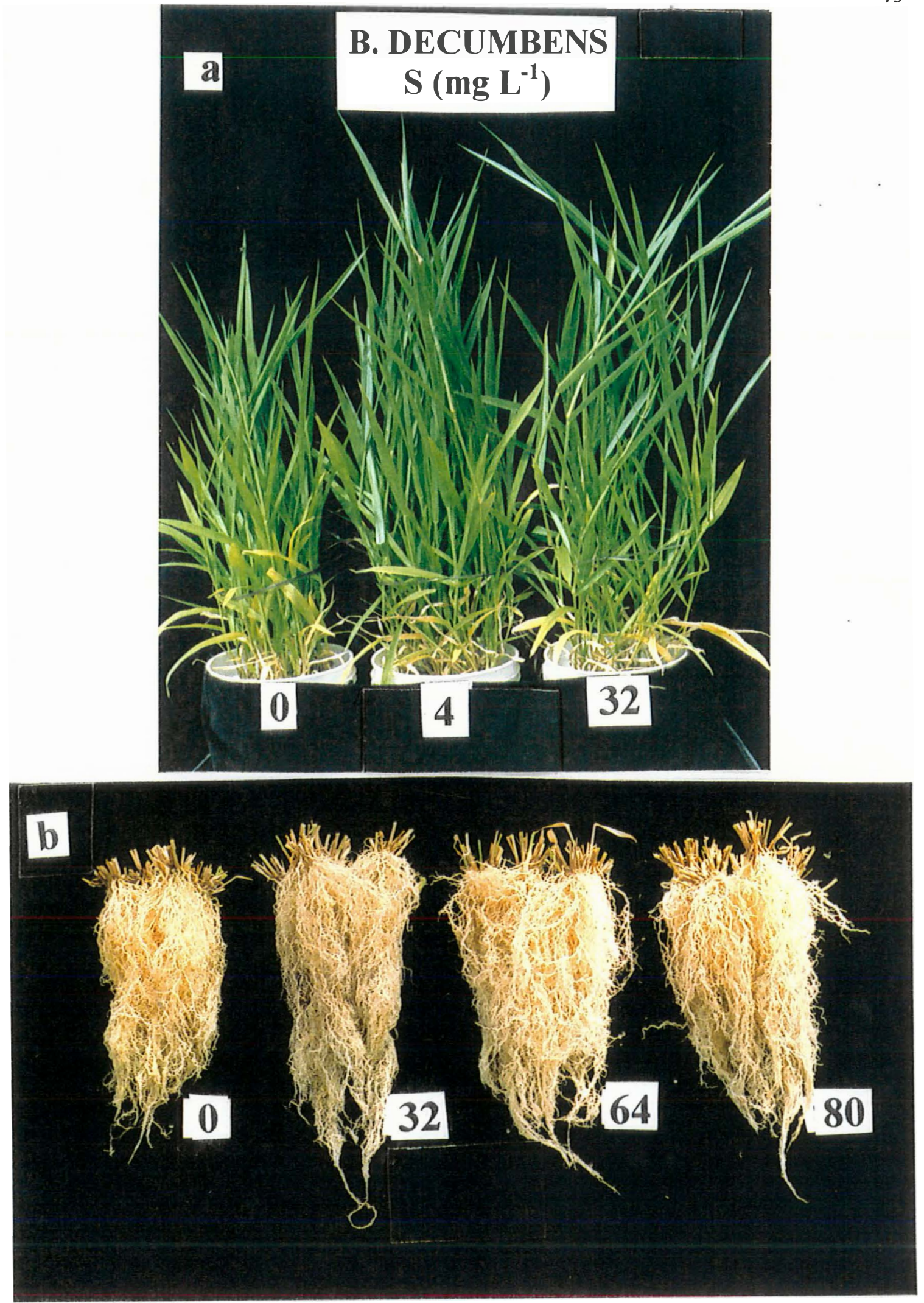

Figura 12 - llustração do efeito das doses de enxofre no desenvolvimento da parte aérea (a) e das raizes (b) de Brachiaria decumbens Stapf. 


\subsubsection{Número de perfilhos no capim-braquiária}

Os resultados demonstraram que no primeiro corte da forrageira não houve influência significativa $(P>0,05)$ das doses de enxofre no perfilhamento da braquiária, mas tal efeito foi significativo $(P<0,01)$ no segundo corte (Figura 13). Nesse corte verificou-se que as doses de enxofre de 64 e $80 \mathrm{mg} \mathrm{L}^{-1}$ não diferiram entre si, mas tiveram número de perfilhos superior às doses mais baixas de enxofre.

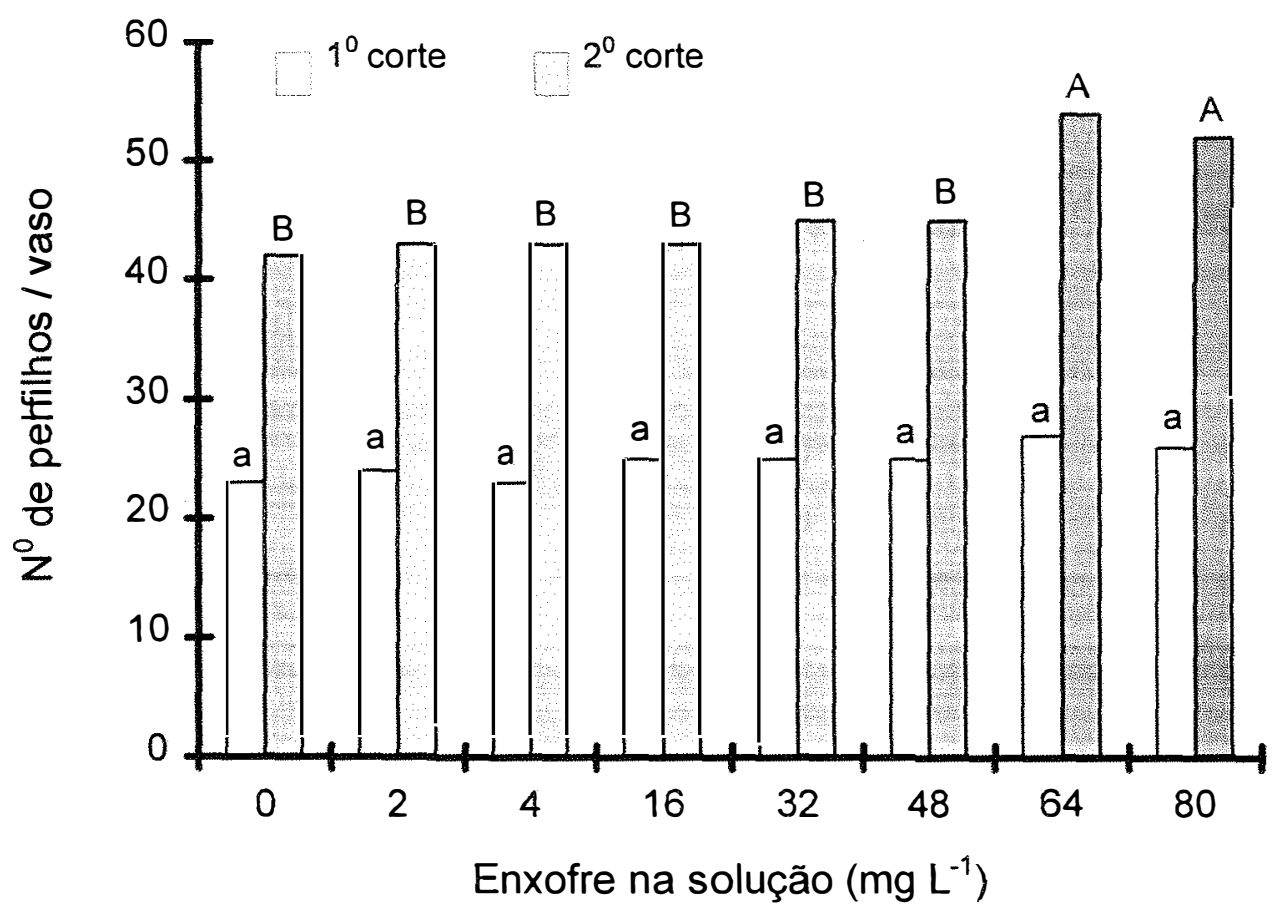

Figura 13 - Número de perfilhos nas cinco plantas no primeiro e segundo cortes da Brachiaria decumbens Stapf., em função das doses de enxofre na solução nutritiva. Letras diferentes entre doses de enxofre, para o mesmo corte, indicam diferenças significativas ao nivel de $5 \%$ de probabilidade pelo teste de Tukey. 
Respostas semelhantes às obtidas neste estudo foram verificadas por Marques et al. (1995) para os capins andropogon e braquiarão cultivados em solo e em condições de omissão de enxofre. Resultados diferentes destes foram observados por Faquin et al. (1995), que verificaram respostas significativas deste nutriente no perfilhamento da braquiária. Estes autores verificaram que a dose de $98 \mathrm{mg}$ de $S \mathrm{~kg}^{-1}$ de solo foi a que resultou no número máximo de perfilhos no capim-braquiária. Além disso, não constataram influência do enxofre sobre $\circ$ perfilhamento do capim-colonião. Efeito significativo do enxofre no perfilhamento do capim-marandu cultivado em solução nutritiva foi verificado por Monteiro et al. (1995).

Esta diferença do número de perfilhos entre os dois crescimentos da forrageira pode ser devido ao melhor estabelecimento do sistema radicular existente no segundo crescimento favorecendo uma maior absorção de nutrientes e maior acúmulo de assimilados pela fotossíntese, e de energia necessária para estimular o número de gemas basais existentes. Além disso, o procedimento do corte também estimula o perfilhamento, pois proporciona maior luminosidade na base da planta (Langer, 1963).

\subsubsection{Atividade da redutase do nitrato}

A análise de variância demonstrou que houve efeito significativo $(P<0,01)$ das doses de enxofre na solução sobre a atividade da redutase do nitrato na planta. Os resultados ajustaram-se a um modelo de regressão de segundo grau para os dois crescimentos da forrageira, como demonstra a Figura 14.

Através da observação da Figura 14 verifica-se que na concentração média de $40 \mathrm{mg}$ de $S \mathrm{~L}^{-1}$ de solução, tanto no primeiro como no segundo 
crescimento do capim-braquiária a enzima redutase do nitrato teve igual atividade $\left(0,14 \mu \mathrm{mol}\right.$ de $\left.\mathrm{NO}_{2} \mathrm{~h}^{-1} \mathrm{~g}^{-1}\right)$.

Ainda na primeira fase de crescimento ficou demonstrado, através da equação de regressão, que a dose de $66 \mathrm{mg}$ de $S \mathrm{~L}^{-1}$ foi a que promoveu a máxima atividade da redutase do nitrato $\left(0,15 \mu\right.$ moles de $\left.\mathrm{NO}_{2} \mathrm{~h}^{-1} \mathrm{~g}^{-1}\right)$.

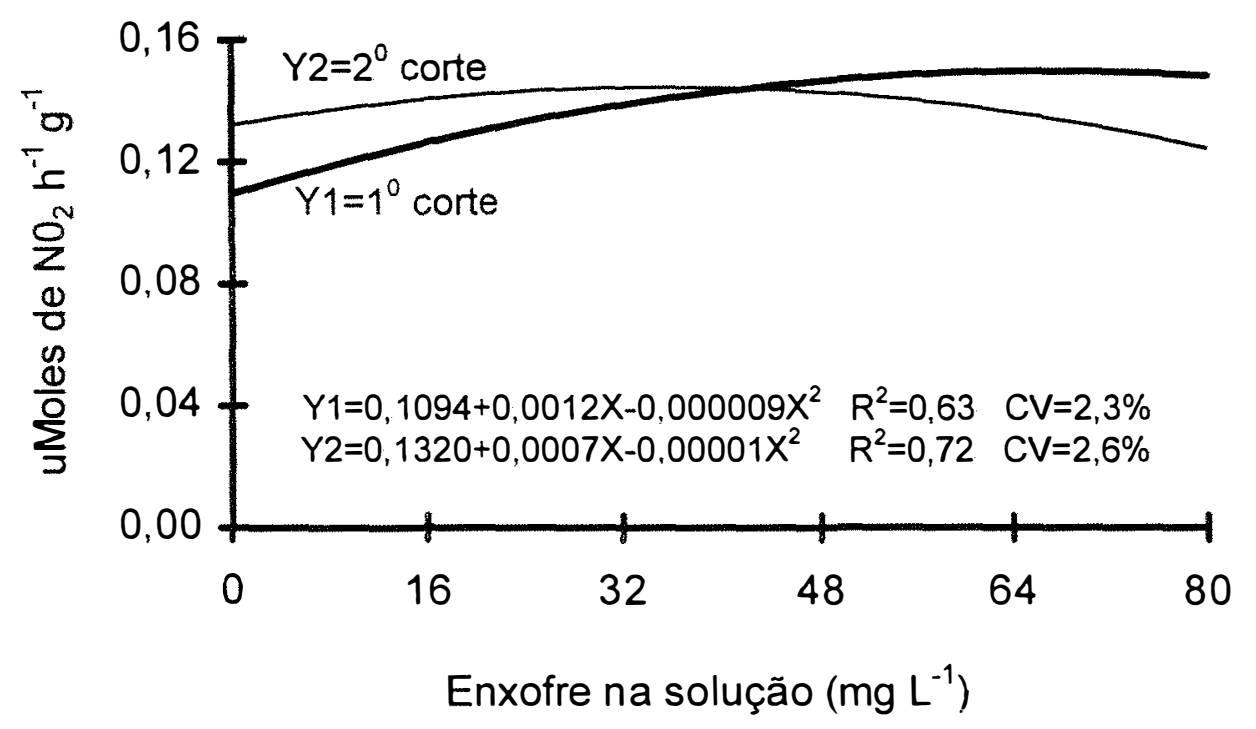

Figura 14 - Atividade da enzima redutase do nitrato no primeiro e segundo crescimentos da Brachiaria decumbens Stapf., em função das doses de enxofre na solução nutritiva. $\quad C V=$ Coeficiente de variação.

No segundo crescimento da forrageira, a máxima atividade enzimática foi de $0,14 \mu$ moles de $\mathrm{NO}_{2} \mathrm{~h}^{-1} \mathrm{~g}^{-1}$, e foi obtida na dose de $35 \mathrm{mg}$ de $S L^{-1}$, a qual representa $53 \%$ da concentração de enxofre correspondente à máxima atividade no primeiro crescimento.

Os valores da atividade da redutase do nitrato deste estudo foram inferiores aos obtidos por Fernandes \& Freire (1976) para a mesma espécie de 
braquiária e por Corrêa (1996) para os capins Colonião e Vencedor. Entretanto, estes valores foram superiores aos encontrados por Abreu (1994), que avaliou o efeito de doses de nitrogênio na atividade dessa enzima nos capins Gordura, Marandu e Tanzânia-1.

A influência do enxofre na atividade da enzima redutase do nitrato não tem sido reportada com unanimidade na literatura. De acordo com Schrader et al. (1968) a planta deficiente em enxofre apresenta pouca ou nenhuma síntese de proteína. Além disso, nessa condição a redutase do nitrato teria a sua meia-vida e a sua atividade mais rapidamente reduzida ou inibida do que muitas outras enzimas na planta.

Friedrich \& Schrader (1978) citaram que em plantas de milho com deficiência de enxofre a concentração de nitrogênio protéico diminuiu e o não protéico aumentou. Verificaram que a redução do nitrato e a assimilação do amônio foram igualmente afetados nessas condições. Reuveny et al. (1980) citaram que, em cultura de fumo deficiente em enxofre, a atividade da redutase do nitrato é rápida e drasticamente reduzida devido à acumulação de produtos finais provenientes da redução do nitrato até aminoácidos, nitrito e amônio. Entretanto, Srivastava (1980) relatou que o suprimento externo desses produtos (nitrito, amônio e aminoácidos) pode aumentar, diminuir ou apresentar pouco ou nenhum efeito na atividade da redutase do nitrato nas plantas. Entretanto, há dificuldades de se determinarem os efeitos causados por esses aminoácidos supridos de forma inter e intracelular no funcionamento normal das plantas. 


\subsubsection{Estimativa do teor de clorofila através do valor SPAD}

As variações nas unidades de valor SPAD, referentes ao teor de clorofila determinados no limbo foliar da planta foram significativas $(P<0,01)$ em função das doses de enxofre na solução nutritiva. Os valores dessas unidades ajustaram-se a um modelo quadrático nos dois períodos de crescimento da forrageira (Figura 15).

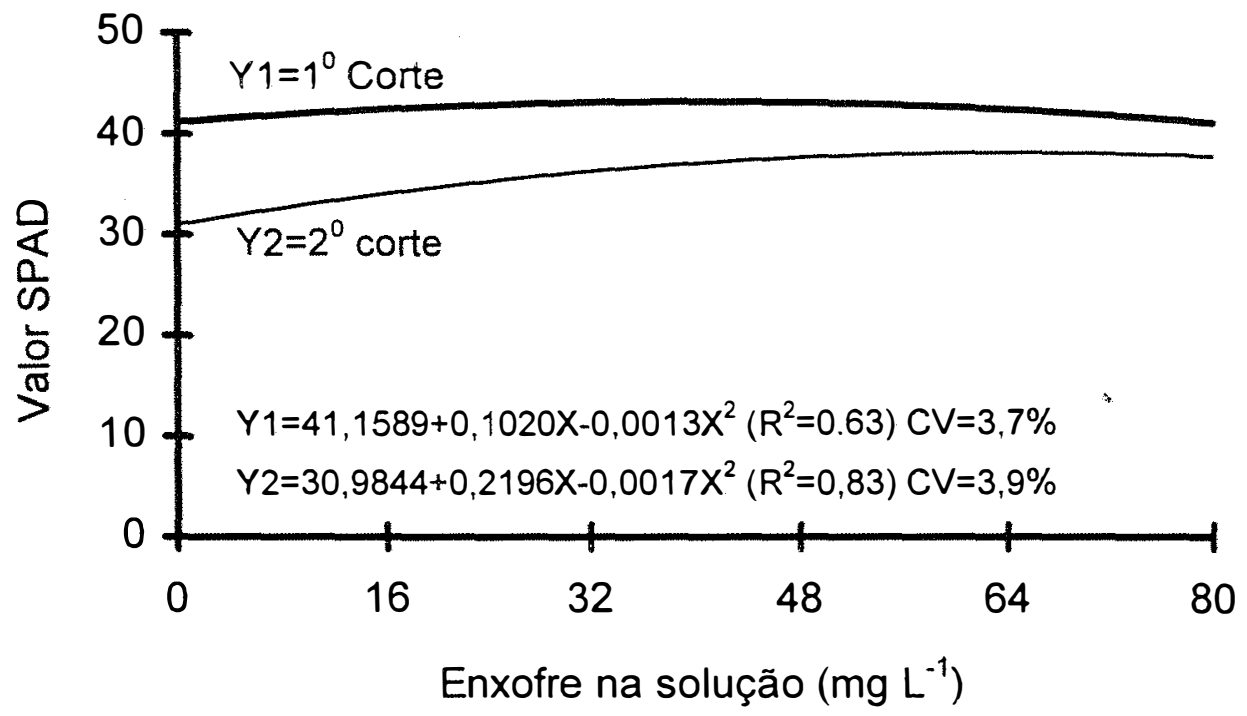

Figura 15 - Teor de clorofila determinado em unidade de valor SPAD no primeiro e segundo cortes da Brachiaria decumbens Stapf., em função das doses de enxofre na solução nutritiva. CV= Coeficiente de variação.

No primeiro crescimento a dose de enxofre de $39 \mathrm{mg} \mathrm{L}^{-1}$ de solução foi a que proporcionou o máximo teor de clorofila, representado pela medida do clorofilômetro que foi de 43,1 valor SPAD. A variação dos valores SPAD referentes aos teores de clorofila, em função das doses de enxofre foi próxima 
a $5 \%$ entre a condição de omissão de enxofre e a dose referente ao máximo teor de clorofila.

No segundo crescimento da forrageira foi observado que a dose de enxofre de $65 \mathrm{mg} \mathrm{L}^{-1}$ foi a que proporcionou o máximo teor de clorofila o qual correspondeu a 38 unidades de valor SPAD. Nesse crescimento houve um aumento de $23 \%$ no teor de clorofila, entre as doses de enxofre mais baixas e aquela correspondente ao valor máximo de SPAD. Esses resultados confirmam a importância do enxofre na formação das moléculas de clorofila, fato já citado por muitos autores, entre os quais Malavolta (1974) e Marschner (1995).

As leituras do clorofilômetro no primeiro crescimento foram sempre superiores às leituras observadas no segundo crescimento da forrageira nas concentrações correspondentes de enxofre na solução. No segundo ciclo vegetativo, em função da maior produção de matéria seca, pode ter ocorrido um efeito de diluição do enxofre e consequentemente da concentração de clorofila na lâmina foliar. É importante ressaltar que os valores das leituras do clorofilômetro expressam a pigmentação de clorofila através da quantidade de luz que é transmitida pela lâmina foliar amostrada.

Apesar dos poucos estudos referentes à determinação do teor de clorofila para estimar o estado nutricional das plantas, resultados satisfatórios têm sido observados em algumas culturas de arroz (Chubachi et al., 1986; Turner \& Jund, 1991; Peng et al., 1993), de milho (Piekielek \& fox, 1992; Smeal and Zang, 1994; Piekielek et al., 1995) e de trigo (Fox et al., 1994), em função de doses de nitrogênio. Mayol (1996), utilizando o clorofilômetro, observou aumento de 1,13 e 1,09 vezes na concentração de clorofila devido ao incremento de doses de ferro em solução nutritiva.

De acordo com Friedrich \& Schrader (1978), a redução do teor de enxofre nas plantas proporciona uma acentuada diminuição na concentração de clorofila e degeneração dos cloroplastos. 
O teor de clorofila nas lâminas de folhas novas apresentou baixo coeficiente de correlação com a concentração de enxofre nessa mesma parte da planta, sendo de 0,31 e 0,64 no primeiro e segundo crescimentos, respectivamente. Isso indica que o uso do clorofilômetro para se estimar a concentração de enxofre nas lâminas de folhas novas do capim-braquiária é de baixa confiabilidade.

\subsubsection{Concentração de enxofre nos componentes da parte aérea}

A análise de variância revelou que houve significância $(P<0,01)$ do efeito das doses de enxofre na solução nutritiva sobre a concentração de enxofre na forrageira. Os resultados apresentados na Figura 16 demonstram ajuste a um modelo de primeiro grau para as folhas não-expandidas da planta, o que caracteriza potencialidade de aumento desta concentração com a adição de doses de enxofre mais elevadas que as utilizadas neste estudo. Nas demais partes da forrageira como lâminas de folhas novas, lâminas de folhas velhas e colmos+bainhas os resultados ajustaram-se a um modelo de segundo grau.

A análise das equações de regressão apresentadas na Figura 16, permite obter as doses de enxofre na solução nutritiva que promoveram as máximas concentrações deste nutriente nos componentes da planta. A concentração de $2.0 \mathrm{~g}_{\text {de S kg-1 }}{ }^{-1}$ de matéria seca nos brotos da planta foi obtida na dose de $80 \mathrm{mg}$ de $S L^{-1}$ de solução. Neste período de crescimento, obsservou-se que a máxima concentração de enxofre nas lâminas de folhas novas foi de $1,6 \mathrm{~g}_{\text {de }} \mathrm{S} \mathrm{kg}{ }^{-1}$ na matéria seca, a qual foi obtida na dose de $42 \mathrm{mg}$ de $S L^{-1}$. Nas lâminas de folhas velhas, a máxima concentração foi de $1,9 \mathrm{~g}$ de $S \mathrm{~kg}^{-1}$ obtida na dose de $49 \mathrm{mg}$ de $\mathrm{S} \mathrm{L}^{-1}$, enquanto nos colmos+bainhas essa 
concentração máxima foi de $2,1 \mathrm{~g}$ de $S \mathrm{~kg}^{-1}$ quando a dose de enxofre foi de 65

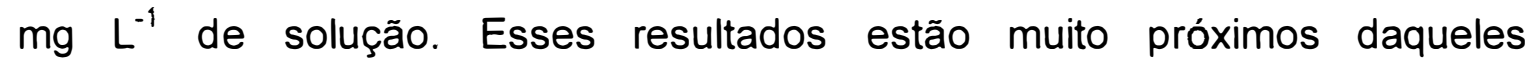
encontrados por Faquin et al. (1995a) que foi de $1,7 \mathrm{~g} \mathrm{de} \mathrm{kg}^{-1}$ de matéria seca na parte aérea do capim-braquiária.

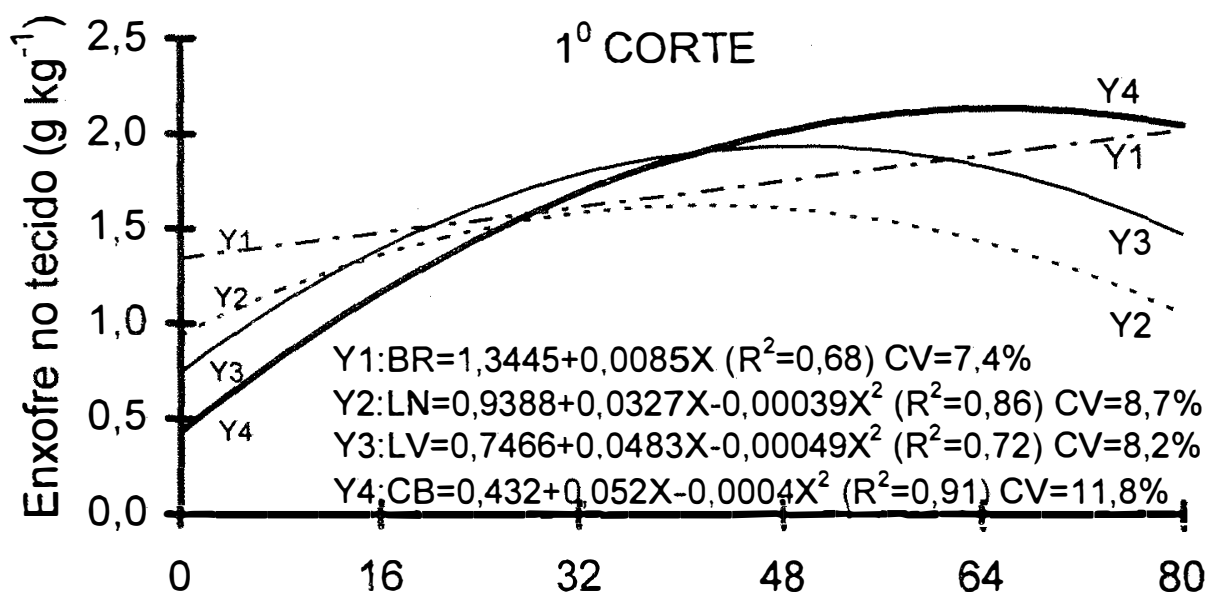

Enxofre na solução $\left(\mathrm{mg} \mathrm{L}^{-1}\right)$

Figura 16 - Concentração de enxofre nas partes da planta (BR=folhas nãoexpandidas, $L N=$ lâminas de folhas novas, $L V=$ lâminas de folhas velhas e $\mathrm{CB}=$ colmos+bainhas) no primeiro corte da Brachiaria decumbens Stapf., em função das doses de enxofre na solução nutritiva. CV= Coeficiente de variação.

Em condições de baixas doses de enxofre no substrato verificou-se quie nas folha não expandidas e nas lâminas de folhas novas ocorreram as mais elevadas concentrações desse nutriente. Por outro lado, os colmos+bainhas e as lâminas de folhas velhas foram as partes da forrageira onde ocorreram as mais baixas concentrações de enxofre. 
Nas doses acima de $32 \mathrm{mg}$ de $S L^{-1}$ na solução a concentração desse nutriente no tecido vegetal foi mais baixa nas lâminas de folhas novas, quando comparada à das demais partes da planta. Esse comportamento pode ser explicado pela baixa mobilidade do enxofre no floema, não se redistribuindo de órgãos mais velhos para os mais novos da planta.

Utilizando as equações de regressão pode-se constatar que o incremento de enxofre até a máxima concentração deste nutriente nos componentes da parte aérea da planta, apresentou valores da ordem de 1,5 vezes nas folhas não-expandidas; de 1,8 vezes nas lâminas de folhas novas; de 1,5 vezes nas lâminas de folhas velhas e de 4,8 vezes nos colmos+bainhas. Assim verifica-se que, entre os componentes da parte aérea do capimbraquiária, o maior aumento da concentração de enxofre ocorreu nos colmos+bainhas com o aumento na disponibilidade do nutriente na solução.

A análise de variância revelou significância $(P<0,01)$ da variação na concentração de enxofre na planta, em função das doses desse nutriente em solução durante o segundo crescimento. Pela observação da Figura 17 nota-se que em cada componente da parte aérea da planta houve ajuste a modelo quadrático.

Nos colmos+bainhas, conforme equação de regressão apresentada, a máxima concentração de enxofre foi de $1,7 \mathrm{~g} \mathrm{~kg}^{-1}$ de matéria seca e foi obtida na dose de $61 \mathrm{mg}$ de $\mathrm{S} \mathrm{L}^{-1}$ de solução. Considerando os valores mínimo e máximo da concentração de enxofre verificou-se um incremento dessa concentração na ordem de três vezes nos colmos+bainhas.

Nas folhas não-expandidas e nas lâminas de folhas novas foi observado que as máximas concentrações de enxofre $\left(1,7\right.$ e $1,8 \mathrm{~g} \mathrm{~kg}^{-1}$, respectivamente) foram obtidas na dose de $72 \mathrm{mg}$ de $\mathrm{S} \mathrm{L}^{-1}$ de solução. Nestes componentes da forrageira verificou-se que houve um aumento nessa concentração da ordem de 2,3 e 2,7 vezes, respectivamente. 
Nas lâminas de folhas velhas a máxima concentração foi de $2,0 \mathrm{~g}$ de $S \mathrm{~kg}^{-1}$ de matéria seca, obtida na dose de $42 \mathrm{mg}$ de $\mathrm{S} \mathrm{L}^{-1}$ de solução, representando um incremento de 2,2 vezes entre o mínimo e o máximo na concentração de enxofre.

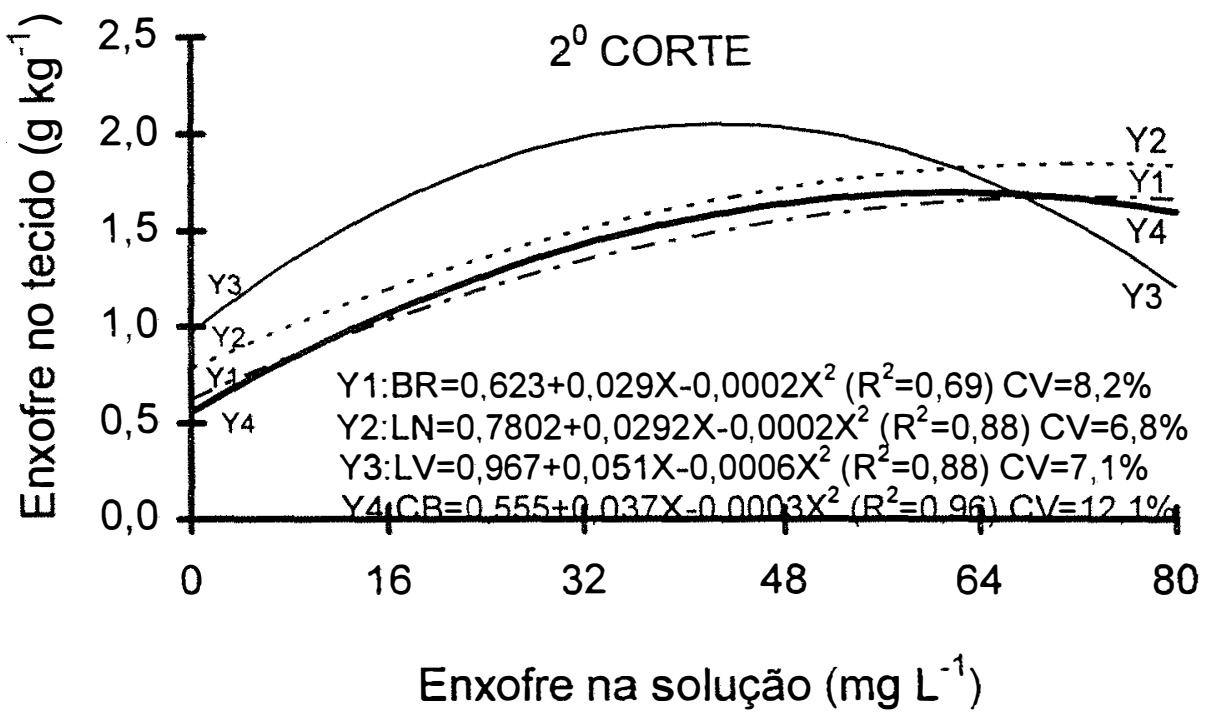

Figura 17 - Concentração de enxofre nas partes da planta $(B R=$ folhas nãoexpandidas, $L N=$ lâminas de folhas novas, $L V=$ lâminas folhas velhas e $C B=$ colmos+bainhas) no segundo corte da Brachiaria decumbens Stapf., em função das doses de enxofre na solução nutritiva. $C V=$ Coeficiente de variação.

As plantas quando submetidas à doses inferiores a $64 \mathrm{mg}$ de $\mathrm{S} \mathrm{L}^{-1}$ apresentaram concentração mais elevada desse nutriente nas lâminas de folhas velhas. Este comportamento pode ser justificado pelo fato da baixa mobilidade do elemento no floema, não o translocando suficientemente para suprir os órgãos mais novos da forrageira. 
As concentrações de enxofre obtidas neste estudo foram superiores àquelas encontradas por Gallo el al. (1974) de $1,4 \mathrm{~g} \mathrm{de} \mathrm{S} \mathrm{kg}^{-1}$ de matéria seca no capim-braqiária e por Faquin et al. (1995b) de $0,8 \mathrm{~g}$ de $\mathrm{S} \mathrm{kg}^{-1}$ no capimBraquiarão e de $0,6 \mathrm{~g}_{\text {de }} \mathrm{S} \mathrm{kg}^{-1}$ no capim-Andropogon.

\subsubsection{Concentração de enxofre nas raízes}

Pela análise de variância pode-se verificar efeito significativo $(P<0,01)$ das doses de enxofre na concentração deste elemento nas raízes do capim-braquiária. Os resultados revelaram ajuste a modelo de segundo grau (Figura 18).

A equação de regressão apresentada na Figura 18 indica que a dose de $72 \mathrm{mg}$ de $S L^{-1}$ de solução foi a que resultou na máxima concentração desse nutriente nas raizes, a qual foi de $2,3 \mathrm{~g}_{\text {de }} \mathrm{S} \mathrm{kg}^{-1}$ de matéria seca. Esse resultado mostra que houve um incremento de três vezes na quantidade de enxofre quando se compara a mínima e a máxima concentração desse nutriente nesta parte da planta. 


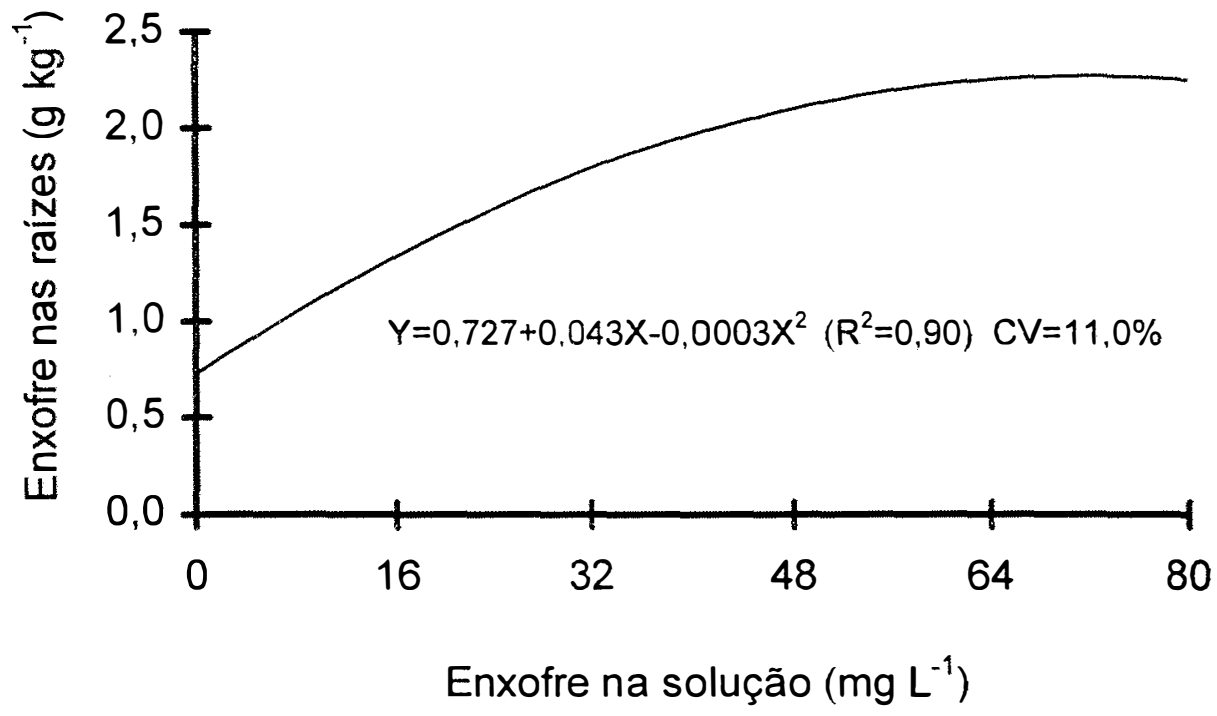

Figura 18 - Concentração de enxofre nas raízes da Braqhiaria decumbens Stapf., em função das doses de enxofre na solução nutritiva. $C V=$ Coeficiente de variação.

\subsubsection{Acúmulo de enxofre nos componentes da planta}

$\mathrm{Na}$ Tabela 5 estão apresentadas as equações de regressão referentes ao acúmulo de enxofre nos componentes da parte aérea e na parte aérea toda por ocasião do primeiro e do segundo corte da forrageira. $O$ acúmulo de enxofre no capim-braquiária foi obtido multiplicando-se as concentrações deste nutriente em cada componente (folhas não-expandidas, lâminas de folhas novas, lâminas de folhas velhas e colmos+bainhas) e na parte aérea da forrageira pela produção de matéria seca de cada componente e da parte aérea dividindo-se esses produtos por 1000.

Através da análise de variância verificou-se efeito significativo $(P<0,01)$ das doses deste nutriente na solução sobre a quantidade de enxofre acumulada na matéria seca dos componentes e na parte aérea da planta. 
No primeiro crescimento da forrageira o acúmulo de enxofre nas folhas não-expandidas aumentou linearmente com o aumento das doses de enxofre na solução. Isto indica que essa gramínea pode acumular nesta parte maior quantidade deste nutriente quando cultivada em condições de disponibilidades mais elevadas de enxofre que as utilizadas neste estudo. Nos demais componentes da planta o acúmulo de enxofre seguiu um modelo de segundo grau.

Utilizando-se as equações de regressão pode-se obter que o maior acúmulo de enxofre entre os componentes da forrageira ocorreu nos colmos+bainhas na dose de $79,7 \mathrm{mg}$ de S L L ${ }^{-1}$ de solução, nas lâminas de folhas novas na dose de $41,7 \mathrm{mg}$ de $S L^{-1}$ de solução, enquanto nas lâminas de folhas velhas na dose de $72 \mathrm{mg} \mathrm{L}^{-1}$ de solução. Na parte aérea o máximo acúmulo de enxofre no primeiro corte, foi obtido na dose de $64 \mathrm{mg}$ de $\mathrm{S} \mathrm{L}^{-1}$ de solução.

No segundo corte da forrageira o acúmulo de enxofre foi explicado através de uma equação de segundo grau para todos os componentes e na parte aérea toda. Foi observado que a maior quantidade de enxofre acumulado na parte aérea foi obtida na dose de $64 \mathrm{mg}$ de $S L^{-1}$ de solução. Verificou-se que apesar da mesma concentração de $64 \mathrm{mg}$ de $S L^{-1}$ promover o acúmulo máximo deste nutriente nos dois cortes da forrageira, a quantidade acumulada no primeiro representou $44,5 \%$ do enxofre acumulado no segundo corte. Essas informações indicam a necessidade de maior quantidade do nutriente no segundo do que no primeiro crescimento da forrageira. 
Tabela 5 - Equações de regressão referentes ao acúmulo de enxofre (y) nos componentes e na parte aérea da Brachiaria decumbens Stapf., no primeiro e segundo crescimentos, em função das doses de enxofre na solução $(x)$.

\begin{tabular}{lcc}
\hline Parte da planta & \multicolumn{1}{c}{ Equação } & $R^{L}$ \\
\hline Folhas não-expandidas & $Y=1,208+0,013 X$ & 0,68 \\
Lâminas de folhas novas & $Y=3,732+0,167 X-0,002 X^{2}$ & 0,84 \\
Lâminas de folhas velhas & $Y=1,589+0,144 X-0,001 X^{2}$ & 0,82 \\
Colmos+bainhas & $Y=2,352+0,319 X-0,002 X^{2}$ & 0,90 \\
Parte aérea & $Y=8,906+0,641 X-0,005 X^{2}$ & 0,93 \\
\hline & Segundo cultivo & 0,87 \\
\hline Folhas não-expandidas & $Y=0,726+0,083 X-0,0006 X^{2}$ & 0,89 \\
Lâminas de folhas novas & $Y=4,273+0,296 X-0,002 X^{2}$ & 0,94 \\
Lâminas de folhas velhas & $Y=4,411+0,366 X-0,004 X^{2}$ & 0,97 \\
Colmos+bainhas & $Y=7,058+0,798 X-0,005 X^{2}$ & 0,96 \\
Parte aérea & $Y=16,469+1,544 X-0,012 X^{2}$ \\
\hline
\end{tabular}

A maior quantidade de enxofre acumulado nas folhas nãoexpandidas ocorreu na dosagem de $69 \mathrm{mg}$ de $S \mathrm{~L}^{-1}$ de solução, sendo este 0 componente da planta onde houve menor acúmulo deste nutriente, representando apenas $5 \%$ do enxofre acumulado na parte aérea. Por outro lado, o maior acúmulo foi observado nos colmos+bainhas mediante a dose de $79,8 \mathrm{mg} \mathrm{L}^{-1}$ de solução. Essa quantidade acumulada nos colmos+bainhas significa $51 \%$ do total deste nutriente na parte aérea. Nas lâminas de folhas 
velhas e nas lâminas de folhas novas os maiores acúmulos de enxofre foram obtidos nas doses de 46 e $74 \mathrm{mg}$ de $S^{-1}$ de solução, respectivamente.

A relação porcentual da distribuição da quantidade de enxofre acumulada nos componentes (folhas não-expandidas, lâminas de folhas novas, lâminas de folhas velhas e colmos+bainhas) em relação a parte aérea da forrageira, no primeiro e segundo cortes é apresentada na Tabela 6.

Tabela 6. Valores porcentuais (\%) da distribuição de enxofre nos componentes da parte aérea da Brachiaria decumbens Stapf. em relação ao enxofre acumulado na parte aérea $(P A=100)$ nos dois corte em função das doses de enxofre na solução.

\begin{tabular}{l|c|c|c|c|c|c|c|c}
\hline \multirow{2}{*}{$\mathrm{S}$} & \multicolumn{4}{|c|}{ Primeiro corte } & \multicolumn{4}{c}{ Segundo corte } \\
\cline { 2 - 9 } $\mathrm{mg} \mathrm{L}^{-1}$ & BR & L N & LV & CB & BR & L N & LV & CB \\
\hline 0 & 13 & 55 & 11 & 21 & 4 & 16 & 33 & 47 \\
2 & 12 & 39 & 20 & 29 & 3 & 23 & 27 & 47 \\
4 & 13 & 33 & 22 & 32 & 5 & 26 & 21 & 48 \\
16 & 8 & 32 & 17 & 43 & 4 & 23 & 22 & 51 \\
32 & 7 & 31 & 21 & 41 & 5 & 22 & 24 & 49 \\
48 & 8 & 29 & 23 & 40 & 5 & 22 & 21 & 52 \\
64 & 6 & 30 & 14 & 50 & 6 & 21 & 14 & 59 \\
80 & 6 & 24 & 19 & 46 & 5 & 25 & 11 & 59 \\
\hline
\end{tabular}

$\mathrm{BR}=$ folhas não-expandidas; $\mathrm{LN}=$ lâminas de folhas novas; $\mathrm{LV}=$ lâminas de folhas velhas; $C B=$ colmos + bainhas. 
No primeiro corte, nos colmos+bainhas, foi observado que com a elevação das doses de enxofre em solução os valores porcentuais da distribuição de enxofre aumentaram e variaram de 21 a $50 \%$. No segundo corte essa variação foi de 47 a $59 \%$ do enxofre acumulado na parte aérea total da planta, e, nas três doses de enxofre mais baixas deste estudo, constatou-se incremento da quantidade de enxofre nas lâminas de folhas novas, enquanto que nas lâminas de folhas velhas esse porcentual foi decrescente.

O menor acúmulo de enxofre entre os componentes da planta foi observado nas folhas não-expandidas, em ambos os crescimentos. Nas lâminas de folhas novas verificaram-se os maiores porcentuais de distribuição desse nutriente em relação às demais partes quando as plantas foram cultivadas nas três concentrações mais baixas do nutriente na solução. $A$ distribuição porcentual do enxofre nessa parte da planta foi também decrescente, como verificado nos brotos. Em condições de baixa disponibilidade do nutriente, a planta provavelmente é induzida a ter proporções mais elevadas do nutriente nas partes de maior atividade meristemática.

Ainda na Tabela 6 , pode-se notar que no segundo crescimento o menor e o maior porcentual de distribuição de enxofre ocorreu nas folhas nãoexpandidas e nos colmos+bainhas, respectivamente. Nas duas mais elevadas doses de enxofre (64 e $80 \mathrm{mg}$ de $S^{-1}$ ), o porcentual de enxofre acumulado foi menor nas lâminas de folhas velhas em relação às lâminas de folhas novas.

\subsubsection{Relação N:S no capim-braquiária}

A relação entre os teores de nitrogênio e enxofre (N:S) foi avaliada nos componentes do capim-braquiária nos dois cortes em função das doses de enxofre na solução, estando os resultados apresentados na Tabela 7. 
No primeiro corte observou-se que os valores da relação $\mathrm{N}: \mathrm{S}$ nas folhas não-expandidas e nos colmos+bainhas apresentaram as mais baixas variações entre o menor e o maior valor dessa relação em função do incremento de enxofre na solução.

Tabela 7. Relação entre a concentração de nitrogênio e enxofre (N:S) nos componentes da parte aérea da Brachiaria decumbens Stapf., nos dois cortes, em função das doses de enxofre na solução.

\begin{tabular}{l|cc|c|c|c|c|c|c}
\hline \multirow{2}{*}{$\begin{array}{l}S \\
\mathrm{mg} \mathrm{L}^{-1}\end{array}$} & \multicolumn{4}{|c|}{ Primeiro corte } & \multicolumn{4}{c}{ Segundo corte } \\
\cline { 2 - 9 } & BR & L N & L V & CB & BR & L N & L V & CB \\
\hline 0 & 15,2 & 20,0 & 35,0 & 10,6 & 43,9 & 51,9 & 16,1 & 39,8 \\
2 & 15,0 & 13,0 & 16,9 & 11,2 & 28,6 & 27,2 & 12,6 & 16,3 \\
4 & 15,0 & 11,7 & 15,2 & 12,8 & 15,9 & 14,0 & 10,6 & 14,1 \\
16 & 14,9 & 11,5 & 11,7 & 11,1 & 13,0 & 13,8 & 9,2 & 10,0 \\
32 & 15,7 & 10,1 & 11,7 & 12,3 & 13,1 & 12,0 & 5,8 & 8,2 \\
48 & 14,3 & 11,5 & 10,7 & 10,5 & 13,0 & 10,4 & 6,1 & 6,6 \\
64 & 8,2 & 10,3 & 10,7 & 7,4 & 10,8 & 10,3 & 8,9 & 6,2 \\
80 & 9,4 & 8,8 & 6,6 & 6,9 & 12,8 & 8,5 & 10,8 & 6,3 \\
\hline
\end{tabular}

$B R=$ folhas não-expandidas; $L N=$ lâminas de folhas novas; $L V=$ lâminas de folhas velhas; $\mathrm{CB}=$ colmos+bainhas.

A relação $\mathrm{N}: S$ foi mais alta nas folhas não-expandidas que nos colmos+bainhas. As lâminas de folhas novas e as lâminas de folhas velhas apresentaram a mais alta variação (2,5 e 5,3 vezes) respectivamente nos valores dessa relação, considerando o menor e o maior valor observados. 
Nesse crescimento da planta, constatou-se que lâminas de folhas velhas foi o componente mais afetado na relação $\mathrm{N}: \mathrm{S}$ quando adicionou-se a mais baixa dose de enxofre na solução onde não havia esse nutriente.

No segundo corte observou-se que, ao contrário do primeiro, lâminas de folhas velhas foi o componente que apresentou a mais baixa variação ( 1,8 vezes) na relação N:S e colmos+bainhas a mais alta variação $(6,4$ vezes) em função das doses de enxofre. De maneira geral, no primeiro corte as plantas crescidas entre as concentrações de 32 a $64 \mathrm{mg}$ de $\mathrm{S} \mathrm{L}^{-1}$ apresentaram valores da relação $\mathrm{N}: \mathrm{S}$ considerados adequados para o consumo animal, na proporção entre 10:1 e 12:1 conforme citado por Tisdale (1977). No segundo corte, para as mesmas concentrações de enxofre, os componentes folhas não-expandidas e lâminas de folhas novas apresentaram valores dessa relação próximo à faixa nutricional citada. Monteiro \& Carriel (1987) estudaram capim-colonião crescido em solo Podzólico e verificaram uma relação N:S de 13,7:1 no segundo corte. De acordo com Werner \& Monteiro (1988), altas disponibilidades de nitrogênio requer em maior aplicação de enxofre, visto que este nutriente é importante no metabolismo do nitrogênio e na síntese de proteinas.

\subsubsection{Nivel crítico de enxofre no capim-braquiária}

Os resultados do estudo da relação entre as concentrações de enxofre nos componentes e na parte aérea com a produção de matéria seca da planta, referentes ao primeiro crescimento do capim-braquiária, demonstraram não haver significância $(P>0,05)$ para a regressão entre elas. Além disso, os coeficientes de correlação entre as variáveis estudadas são considerados 
baixos (folhas não-expandidas $r=0,66$; lâminas de folhas novas $r=0,47$; lâminas de folhas velhas $r=0,55$; colmos+bainhas $r=0,65$ e parte aérea $r=0,66$ ).

Entretanto, no segundo crescimento constatou-se significância $(P<0,01)$ para as variáveis avaliados. Foram observados coeficientes de correlação da ordem de: 0,76 para as lâminas de folhas novas e para parte aérea; 0,70 para as folhas não-expandidas; 0,46 para lâminas de folhas velhas e 0,72 para colmos+bainhas. Baseando-se nesses resultados as lâminas de folhas novas e a parte aérea foram os componentes da planta considerados adequados para a determinação de níveis críticos de enxofre na braquiária. $O$ conceito de nivel crítico adotado neste estudo foi o estabelecido por Ulrich \& Hills (1973), que define a obtenção deste valor através da concentração do nutriente que corresponde a $90 \%$ da produção ótima da cultura.

$\mathrm{Na}$ Figura 19 são apresentadas as equações de regressão relacionando a concentração de enxofre com a produção de matéria seca no segundo crescimento da forrageira, e que permitiram definir como nivel crítico na parte aérea $0,81 \mathrm{~g}$ de $S \mathrm{~kg}^{-1}$ de matéria seca e nas lâminas de folhas novas $1,0 \mathrm{~g}_{\text {de }} \mathrm{S} \mathrm{kg}{ }^{-1}$ de matéria seca.

Considerando que cada compartimento da forrageira pode apresentar resultados significativamente diferenciados quanto à concentração de enxofre, como demonstraram as Figuras 16 e 17, a amostragem de toda a parte aérea pode não apresentar estabilidade nos resultados, uma vez que a parte amostrada na planta em maior quantidade, no momento da coleta, certamente influenciará no teor de enxofre encontrado na análise. Assim, é preciso maior rigor quando a parte aérea da forrageira for amostrada para fins de diagnóstico nutricional.

Sugere-se que, preferencialmente, sejam amostradas as lâminas de folhas novas para avaliação do estado nutricional de capim-braquiária quanto ao enxofre, por ser de fácil identificação e coleta nas pastagens, além de 
apresentar menor variação nos resultados em relação à parte aérea total da planta.

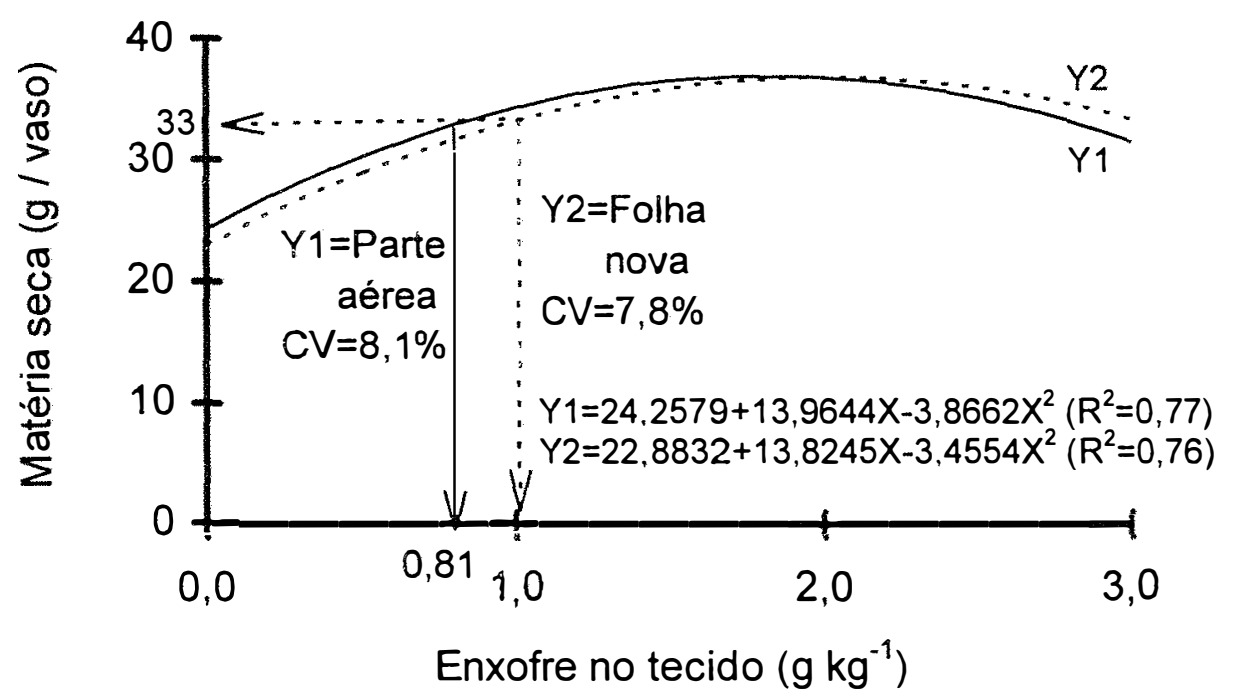

Figura 19 - Relação entre a concentração de enxofre na parte aérea (Y1) e nas lâminas de folhas novas (Y2) no segundo corte, com a produção de matéria seca da parte aérea da Brachiaria decumbens Stapf. $C V=$ Coeficiente de variação.

Os valores de nível crítico de enxofre obtidos neste estudo estão próximos aos observados por Smith \& Siregar (1983) em amostras da parte aérea de braquiária e que variaram entre 0,7 e $1,1 \mathrm{~g} \mathrm{de} \mathrm{kg}^{-1}$ de matéria seca. Resultados semelhantes também foram apontados por Hoffmann (1992) para a mesma forrageira. Entretanto, valores de nivel crítico mais elevados foram obtidos por Faquin et al. (1995a) no primeiro crescimento do capim-braquiária, que foi de $1,0 \mathrm{~g}_{\text {de }} S \mathrm{~kg}^{-1}$ na parte aérea e de $1,2 \mathrm{~g}_{\text {de }} S \mathrm{~kg}^{-1}$ para lâminas de folihas novas. No segundo crescimento foi de 1,5 e $2,4 \mathrm{~g}$ de $S \mathrm{~kg}^{-1}$ para parte aérea e lâminas de folhas novas, respectivamente. Rao et al. (1996) encontraram na parte aérea do capim-braquiária um nivel crítico de enxofre de $1,6 \mathrm{~g} \mathrm{de} \mathrm{S} \mathrm{kg}^{-1}$. 


\subsubsection{Sintomatologia de deficiência de enxofre}

No primeiro crescimento do capim-braquiária a expressão de sintoma visual da deficiência de enxofre foi verificada de forma não intensiva a partir de 30 dias após transplantio, com leve clorose nas lâminas de folhas novas nas doses inferiores a $16 \mathrm{mg}$ de $\mathrm{S} \mathrm{L}^{-1}$ de solução. Não foram observadas variações expressivas no crescimento das plantas em função das doses de enxofre.

A influência das doses de enxofre no crescimento e no aparecimento de sintomas característicos da deficiência deste nutriente foram observados com maior definição no segundo crescimento da braquiária.

Duas semanas após o primeiro corte da braquiária foram observados sintomas de deficiência de enxofre nas plantas submetidas às mais baixas doses de enxofre (abaixo de $16 \mathrm{mg}$ de $S \mathrm{~L}^{-1}$ ). Ao final do período do segundo crescimento constatou-se a presença de grande número de plantas com lâminas de folhas novas cloróticas e leve clorose com tendência a verde pálido nos demais componentes da parte aérea. Contudo, não foi observado outro sintoma externo de deficiência de enxofre (como enrolamento das margens das folhas, folhas pequenas, desfolhamento, tecido necrosado) conforme comprovado e relatado por outros autores (Mengel \& Kirkby, 1987; Marschner, 1995; Mikkelsen \& Camberato, 1995; Malavolta. 1997). 


\subsection{Conclusões}

Os resultados desse experimento permitem apresentar as seguintes conclusões:

- O aumento das doses de enxofre em solução proporcionou aumentos na produção de matéria seca da parte aérea e das raízes do capim-braquiária. O número de perfilhos não sofreu influência das doses de enxofre no primeiro crescimento, mas foi incrementado no segundo crescimento nas doses 64 e $80 \mathrm{mg}$ de $S^{-1}$ de solução nutritiva .

- A atividade da redutase do nitrato e o teor de clorofila nos dois crescimentos da forrageira foram estimulados pelas doses de enxofre na solução nutritiva.

- A concentração de enxofre foi mais baixa nos colmos+bainhas nas doses mais baixas e nas lâminas de folhas novas nas doses mais altas de enxofre na solução, no primeiro crescimento. No segundo crescimento a concentração mais elevada de enxofre ocorreu nas lâminas de folhas velhas. $O$ acúmulo de enxofre foi menor nas folhas não-expandidas e maior nos colmos+bainhas, nos dois crescimentos da forrageira.

- As lâminas de folhas novas são indicadas para a avaliação do stado nutricional em enxofre no capim-braquiária e o nível crítico está entre 0,81 e $1,0 \mathrm{~g}_{\text {de }} \mathrm{S} \mathrm{kg}^{-1}$ de matéria seca. 


\section{REFERÊNCIAS BIBLIOGRÁFICAS}

ABREU, J.B.R. Niveis de nitrogênio e proporções de nitrato e amônio afetando produção, atividade da redutase do nitrato e composição de três gramíneas forrageiras. Piracicaba, 1994. 109p. Dissertação (Mestrado) - Escola Superior de Agricultura "Luiz de Queiroz", Universidade de São Paulo.

ADAMS, F. Nutritional imbalances and constrainst to plant growth on acid soils. Journal of Plant Nutrition, v.4, n.2, p.81-87, 1981.

ALCÂNTARA, P.B. Origem das braquiárias e suas características morfológicas de interesse forrageiro. In: ENCONTRO PARA DISCUSSĀO DOS CAPINS DO GÊNERO BRACHIARIA, Nova Odessa, 1986. Anais. Nova Odessa: Instituto de Zootecnia, 1987. p.1-14.

ALMEIDA, C.R. de.; MONTEIRO, F.A. Respostas de Cynodon dactylon cv. Coastcross 1 a niveis de nitrogênio em solução nutritiva. In: CONGRESSO BRASILEIRO DE CIÊNCIA DO SOLO, 25.,Viçosa, 1995. Resumos. Viçosa: SBCS;UFV, 1995. p.743-744.

ALVIM, M.J.; BOTREL, M.A.; VERNEQUE, R.DA S.; et al. Aplicação de nitrogênio em acessos de Brachiaria. 1. Efeito sobre a produção de matéria seca. Pasturas Tropicales, v.12, n.2, p.2-6, ago. 1990.

ANDRADE, J.B. de. Estudo comparativo de três capins da espécie Panicum maximum Jacq. (Colonião, Tobiatã e K-187 B). 1987. 133p. Dissertação (Mestrado) - Escola Superior de Agricultura "Luiz de Queiroz", Universidade de São Paulo. 
ANDRADE, S.R.M. Efeito da proporção $\mathrm{NH}_{4}+/ \mathrm{NO}_{3}-$ na composição da fração nitrogenada e na atividade das enzimas de redução e assimilação de nitrogênio em plantas de capim-colonião (Panicum maximum Jacq). Viçosa, 1994. 49p. Dissertação (M.S.) Universidade Federal de Viçosa.

ANDREW, C.S. Mineral nutrition of subtropical pasture species. Journal Australian Institute Agriculture Science, v.31, n.1, p. 56-59, Jan./Apr. 1965.

BEEVERS, L.; HAGEMAN, R.H. Nitrate reduction in higher plants. Annual Review of Plant Physiology, v.20, n.3, p.495-522. 1969.

BLACKMER, T.M.; SCHEPERS, J.S.; VIGIL, M.F. Chlorophyll meter readings in corn as affected by plant spacing. Communications in Soil Science and Plant Analysis, v.24, n.17-18, p. 2507-2516, 1993.

BOIN, C. Produção animal em pastos adubados. In: SIMPÓSIO SOBRE CALAgEM E ADUBAÇĀO DE PAStAgenS, 1., Nova Odessa, 1985. Anais. Piracicaba: Associação Brasileira para a Pesquisa da Potassa e do Fosfato, 1986. p.383-419.

BOTREL, M. de A.; ALVIM, M.J.; MARTINS, C.E. Aplicação de nitrogênio em acessos de Brachiaria. 2. Efeito sobre os teores de proteína bruta e minerais. Pasturas Tropicales, v.12, n.2, p.7-10, ago. 1990.

BREDON, R.N.; HORRELL, C.R. The chemical composition and nutritive value of some common grasses in Uganda - II. The comparison of chemical composition and nutritive value of grasses throughout the year, with special 
reference to the later stage of growth. Tropical Agriculture, v.39, n.1, p.13-17, Jan. 1962.

CAMPBELL, R.J.; MOBLEY, K.N.; MARINI, R.P.; PFEIFFER, D.G. Growing conditions alter the relationship between SPAD-501 values and apple leaf chlorophyll. HortScience, v.25, n.3, p.330-331, Mar. 1990.

CARVALHO, M.M.; MARTINS, C.E.; VERNEQUE, R.da S. \& SIQUEIRA, C. Respostas de uma espécie de Brachiaria à fertilização com nitrogênio e potássio em um solo ácido. Revista Brasileira de Ciência do Solo, v.15, n.2, p.195-200, maio/ago. 1991.

CASAGRANDE, J.C.; SOUZA, O.L. Efeito de niveis de enxofre sobre quatro gramineas forrageiras tropicais em solos sob vegetação de cerrado do Mato Grosso do Sul, Brasil. Pesquisa Agropecuária Brasileira, v.17, n.1, p.21-25, jan. 1982.

CENTRO INTERNACIONAL DE AGRICULTURA TROPICAL. Informe anual. 1978: programa de ganado de carne. Cali, 1978. p.B86-B104: Fertilidade del suelo y nutrición de la planta.

CHUBACHI,T.; ASANO, I.; OIKAWA, T. The diagnosis of nitrogen nutrition of rice plants, using chlorophyll meter. Journal of Soil Science and Plant and Nutrition, v.57, n.2, p.190-193, 1986.

CORREAA, B.D. Doses de nitrogênio e de magnésio afetando aspectos produtivos e bioquímicos dos capins Colonião, Tanzânia-1 e 
Vencedor.Piracicaba, 1996. 76p. Dissertação (Mestrado) - Escola Superior de Agricultura "Luiz de Queiroz", Universidade de São Paulo.

CORSI, M. Effects of nitrogen rates and harvesting intervals on dry matter production, tillering and quality of the tropical grass Panicum maximum Jacq. Ames, 1984. 125p. Thesis (PhD)- Ohio State University.

CORSI, M. Pastagens de alta produtividade. In: SIMPÓSIO SOBRE MANEJO DE PASTAGEM, 8. Piracicaba, 1986. "Anais". Piracicaba: FEALQ, 1985. p.1-14.

DEANNE-DRUMMOND, C. E. Biochemical and biophysical aspects of nitrate uptake and its regulations. In: ABROL, Y. P. (Ed.). Nitrogen in higher plants. Somerset, Research Studies, 1990. p.1-37.

DOW, A.I.; ROBERTS, A.I. Proposal critical nutrient ranges for crops diagnosis. Agronomy Journal, v.74, n.2, p.401-403, Mar./Apr. 1982.

DUKE, S. H. \& REISENAUER, H.M. Roles and requirements of sulfur In plant nutrition. Series In: SULFUR IN AGRICULTURE, Ed. Tabatabai, M. A Agronomy, Madison, 1986. p.123-168.

ERGLE, D.R. \& EATON, F.M. Sulfur nutrition of cotton. Plant Physiology. v.26, n.1, p.639-654, 1951.

FAQUIN, V.; HOFFMANN, C.R.; EVANGELISTA, A.R. \& GUEDES, G.A.A. O potásssio e o enxofre no crescimento da braquiária e do colonião em 
amostras de um latossolo da região noroeste do Paraná. Revista Brasileira de Ciência do Solo, v.19, n.1, p.87-94, jan./abr. 1995a.

FAQUIN, V.; CURI, N.; MARQUES, J.J.G.S.M.; TEIXEIRA, W.G.; EVANGELISTA, A.R.; SANTOS, D. \& CARVALHO, M.M. Limitações nutricionais para gramíneas forrageiras em Cambissolo álico da microrregião Campos da Mantiqueira-MG, Brasil. 2. Nutrição em macro e micronutrientes. Pasturas Tropicales, v.17, n.3, p.17-22, $1995 \mathrm{~b}$.

FAVORETTO, V. Adaptações de plantas forrageiras ao pastejo. In: SIMPÓSIO SOBRE ECOSSISTEMA DE PASTAGENS, 2., Jaboticabal, 1993. Anais. Jaboticabal: FUNEP, 1993. p. 31-42.

FERNANDES, F.M.; ISEPON, O.J.; NASCIMENTO, V.M. Resposta de Brachiaria decumbens Stapf a niveis de N, P e K em solo originalmente coberto por vegetação de cerrado. Científica, v.13, n.1/2, p. 89-97, 1985.

FERNANDES, M.S.; FREIRE, L.R. Efeito de nitrogênio nítrico aplicado ao solo na atividade da nitrato redutase e acumulação de $\mathrm{N}$-proteico com Brachiaria sp. Turrialba, v.26, p. 268-273, 1976.

FERNANDES, M.S.; ROSSIELO, R.O.P. Aspectos do metabolismo e utilização do nitrogênio em gramíneas tropicais, In: SIMPÓSIO SOBRE CALAGEM E ADUBAÇÃO DE PASTAGENS, 1., Nova Odessa, 1985. Anais. Piracicaba: POTAFOS, 1986. p. 93-123. 
FERNANDES, M.S.; FERREIRA, M.B.; FREIRE, L.R. Efeitos da interação de $\mathrm{N}$-nitrato e amônio na atividade da redutase de nitrato e acumulação de $\mathrm{N}$ protéico com Brachiaria sp. Turrialba, v.28, n.3, p.187-191, jul./set. 1978.

FERRARI JÚNIOR, E.; ANDRADE,J.B.de.; PEDREIRA, J.V.S.; CONSENTINO, J.R.; SCHAMMASS, E.A. Produção de feno de Brachiaria decumbens e Brachiaria brizantha cv. Marandu sob três frequências de corte. I. Produção de matéria seca. Boletim de Industria Animal, Nova Odessa, v.51, n.1, p.49-54, jan/jun. 1994.

FERRARI NETO, J. Limitações nutricionais para o colonião (Panicum maximum Jacq) e (Brachiaria decumbens Stapf.) em latossolo da região noroeste do estado do Paraná. Lavras, 1991. 126p. Dissertação (M.S.) Escola Superior de Agricultura de Lavras.

FOX, R.H.; PIEKIELEK, W.P.; MACNEAL, K.M. Using a chlorophyll meter to predict nitrogen fertilizer needs of winter wheat. Communications in Soil Science and Plant Analysis, v.25, n.3/4, p.171-181, 1994.

FRIEDRICH, J.W. \& SCHRADER, L.E. Sulfur deprivation and nitrogen metabolism in maize seedlings. Plant Physiology, v.61, n.2, p.900-903, 1978.

GALLO, J.R.; HIROCE, R.; BATAGLIA, O.C.; FURLANI, P.R.; FURLANI, - A.M.C.; MATTOS, H.B.; SARTINI, H.J. \& FONSECA, M.P. Composição química inorgânica de forrageiras do Estado de São Paulo. Boletim de Indústria Animal, v.31, n.1, p.115-137, jan./jun. 1974. 
GASTAL, F. \& NELSON, C.J. Nitrogen use withing the growing leaf blade of tall fescue. Plant Physiology, v.105, n.1, p.191-197, 1994.

GHISI, O.M.A.A.; ALMEIDA, A.R.P. de; ALCÂNTARA, V. de B.G. Avaliação agronômica de seis cultivares de Panicum maximum Jacq. sob três níveis de adubação. Boletim de Industria Animal, v.46, n.1, p.1-15, 1889.

GOMIDE, J. A. Aspectos biológicos e econômicos da adubação de pastagens. In: ECOSSISTEMA DE PASTAGENS, 1., Jaboticabal, 1989. Anais. Jaboticabal: FUNEP, 1989. p.237-270.

HARDING, W.A.T.; GROF, B. Effect of fertilizer nitrogen on yield, nitrogen content and animal productivity of Brachiaria decumbens cv. Brasilisk on the wet tropical coast of North Queensland. Queensland Journal of Agricutural and Animal Sciences, v.35, n.1, p.11-21, 1978.

HOFFMANN, C.R. Nutrição mineral e crescimento de Brachiaria e do Colonião, sob influencia das aplicações de nitrogênio, fósforo, potássio e enxofre em Latossolo da região noroeste do Paraná. Lavras, 1992. 204p. Dissertação (Mestrado) - Escola Superior de Agricultura de Lavras.

JANSEN, H.H.; BETANY, J.R. Sulfur nutrition of rapeseed: I: Influence of fertilizer nitrogen and sulfur rates. Soil Science Society of America Journal, v.48, n.1, p.100-107, 1984.

JOHNSON, C.B.; WHITTINGTON, W.J.; BLACKWOOD, G.C. Nitrate reductase as a possible predictive test of crop yield. Nature, v.262, n.2, p.133-134, July, 1976. 
KARIA, C.T.; ANDRADE, R. P. de. Avaliação preliminar de espécies forrageiras no centro de pesquisa agropecuária dos cerrados: perspectivas futuras. In: SIMPÓSIO SOBRE CERRADO, 8., Brasilia,1996. Biodiversidade e produção sustentável de alimentos e fibras nos Cerrados: Anais. Planaltina: EMBRAPA,CPAC, 1996. p.35-39.

LANGER, R.H.M. Tillering in herbage grasses. Herbage Abstracts, v.33, n.3, p.141-148, Sept. 1963.

LANGER, R. H. M. How grasses grow. London: Edward Arnold, 1974. 66p.

LAWLOR, D. W. Photosynthesis, productivity and environment. Journal Experiment Botany, v.46, n.1, p.1449-1461, 1995.

MALAVOLTA, E. Elementos de nutrição mineral de plantas. São Paulo: Agronômica Ceres, 1980. 251p.

MALAVOLTA, E. Nutrição mineral. In: FERRI, M.G.(Coord). Fisiologia vegetal. São Paulo: Editora Pedagógica e Universitária; EDUSP, 1979. v.1, p.97-113.

MALAVOLTA, E.; VITTI, G.C.; OLIVEIRA, S.A. de. Avaliação do estado nutricional das plantas: princípios e aplicações. 2.ed. Piracicaba: POTAFOS, 1997. 319p.

MALAVOLTA, E.; HAAG, H. P.; MELLO, F.A.F. \& BRASIL SOBRINHO, M.O.C. Nutrição mineral e adubação de plantas cultivadas. São Paulo: Pioneira, 1974. 727p. 
MARQUES, J.J.G.S.M.; CURI, N.; FAQUIN, V.; TEXEIRA, W.G.; EVANGELISTA, A.R.; SANTOS, D.; CARVALHO, M.M. Limitações nutricionais para gramíneas forrageiras em Cambissolo álico da microrregião Campos da Mantiqueira-MG, Brasil. 1. Produção de matéria seca e perfilhamento. Pasturas Tropicales, v.17, n.3, p.12-16, 1995.

MARSCHNER, $H$. Mineral nutrition in higher plants. Berlin: Academic Press, 1995. 674p.

MAYOL, R.M. Nutrição mineral e desenvolvimento de cultivares de arroz (Oryza sativa L.), cultivados em soluções nutritivas com diferentes concentrações de ferro. Piracicaba, 1996. 114p. Dissertação (Mestrado) - Escola Superior de Agricultura "Luiz de queiroz", Universidade de São Paulo.

MAZZANTI, A. \& LEMAIRE, G. Effect of nitrogen fertilisation on the herbage production of tall fescue swards grazed continuously with sheep. 2 . Consumption and efficiency of herbage utilisation. Grass and Forage Science, v.49 n.2 p.352-359, 1994.

McCLUNG, A. C.; FREITAS, L.M.M. de; LOTT, W.L. Analysis of several Brazilian soils in relation to plant responses to sulfur. Soil Science Society of America Proceedings, v.23, n.2, p.212-214, 1959.

MEIRELLES, N.M.F. Degradação de pastagens - critérios de avaliação. In: . ENCONTRO SOBRE RECUPERAÇÃO DE PASTAGENS. Nova Odessa, 1993. Anais. Nova Odessa: Instituto de Zootecnia, 1993. p.27-47. 
MENGEL, K.; KIRKBY, E.A. Principles of plant nutrition. 4.ed. Bern: International Potash Institute, 1987. 687p.

MIKKELSEN, R. L.; CAMBERATO,J.J. Potassium, sulfur, lime and micronutrient fertilizers. In: RECHCIGL, J.E. (Ed.) Soil amendments and environmental quality. Boca Raton: Lewis Publishers, 1995. p.109-137.

MILFORD, R.; MINSON, S.J. The relation between the crude protein content of tropical pasture plants. Journal of the Bristish Grassland Society, v.20, n.3, p.1977-1979, Sept. 1965.

MILLS, H.A.; BARKER, A.V.; MAYNARD, D.N. Effects of nitrapyrin on nitrate accululation in spinach. Journal of the American Society for Horticultural Science, v.101, p.202-204, 1976.

MINOLTA CAMERA Co. Manual for chlorophyll meter Spad-502. Osaka, 1989. 22p.

MONTEIRO, F.A.; CARRIEL, J.M. Aplicação de níveis de enxofre na forma de gesso para cultivo do capim-colonião em dois solos arenosos do Estado de São Paulo. Boletim de Industria Animal, v.44, n.2, p. 335-347, 1987.

MONTEIRO, F.A.; ONO, M.N. Niveis de enxofre em Brachiaria brizantha cV. Marandu cultivado em solução nutritiva. In: CONGRESSO BRASILEIRO DE - CIÊNCIA DO SOLO, 25.,Viçosa, 1995. Resumos. Viçosa: SBCS/UFV, 1995. p.1021-1022. 
MONTEIRO, F.A.; WERNER, J.C. Efeitos das adubações nitrogenada e fosfatada em capim-colonião, na formação e em pasto estabelecido. Boletim de Indústria Animal. v.34, n.1, p.91-101, jan./jun. 1977.

MONTEIRO, F.A.; RAMOS, A.K.B.; CARVALHO, D.D.de; ABREU, J.B.R.; DAIUB, J.A.S.; SILVA, J.E.P. \& NATALE, W. Cultivo de Brachiaria brizantha Stapf. cv. Marandu em solução nutritiva com omissão de macronutrientes. Scientia Agricola, v.52, n.1, p.135-141, jan./abr. 1995.

MORIKAWA, C.K. Limitações nutricionais para o andropogon (Andropogon gayanus) e braquiarão (Brachiaria brizantha) em Latossolo da região do Campos das Vertentes-MG. Lavras, 1993. 136p. Dissertação (M.S) - Escola Superior de Agricultura de Lavras.

MULDER, E.G.; BOXMA, R.; VAN VEEN, W.L. The effect of molybdenum and nitrogen deficiencies on nitrate reduction in plant tissue. Plant and Soil, v.10, n.4, p. 335-355, Apr. 1959.

MYERS, R.J.K.: ROBBINS, G.B. Sustaining productive pastures in the tropics 5. Maintaining productive sown grass pastures. Tropical Grasslands, v.25, n.2, p.104-110, June, 1991.

NAMBIAR, P.T.C.; REGO, T.J.; RAO, B.S. Nitrate concentration and nitrate reductase activity in the leaves of three legumes and three cereals. Annals of Applied Biology, v.112, n.3, p.547-553, June, 1988. 
NABINGER. C. Eficiência do uso de pastagens: disponibilidade e perdas de forragem. In: SIMPÓSIO SOBRE MANEJO DA PASTAGEM, 14. Piracicaba, 1997. Anais. Piracicaba: FEALQ, 1997. p.213-251.

NASCIMENTO Jr., D. do; QUEIROZ, D.S.; SANTOS, M.V.F. Degradação das pastagens e critérios para avaliação. In: SIMPÓSIO SOBRE MANEJO DA PASTAGEM, 11. Piracicaba, 1994. Anais. Piracicaba: FEALQ, 1994. p.107-151.

NOVOA, R.; LOOMIS, R.S. Nitrogen and plant production. Plant and Soil. v.58, n.1/3, p.177-204, 1981.

OKHI, K. Critical nutrient levels related to plant growth and some physiology processes. Journal of Plant Nutrition, v.10, n.5, p.1583-1590, 1987.

OLIVEIRA, M.A. de. Estudo de crescimento e valor nutritivo do capim brachiaria (Brachiaria decumbens Stapf). Piracicaba, $1980.68 p$. Dissertação (Mestrado) - Escola Superior de Agricultura "Luiz de Queiroz", Universidade de São Paulo.

PENG, S.; GARCÍA, F.V.; LAZA, M.R.C. \& CASSMAN, K.K. Adjustment for specific leaf weight improves chlorophyll meter's estimate of rice leaf nitrogen concentration. Agronomy Journal, v.85, n.1, p.987-990, 1993.

PENG, S.; LAZA, M.R.C.; GARCÍA, F.V. \& CASSMAN, K.G. Chlorophyll meter estimates leaf area-based nitrogen concentration of rice. Communication in Soil Science and Plant Analysis, v.26, n.5-6, p.927-935, 1995. 
PEREIRA, J.P. Adubação de capins do gênero Brachiaria. In: ENCONTRO PARA DISCUSSÃO DOS CAPINS DO GÊNERO BRACHIARIA. Nova Odessa, 1986. Anais. Nova Odessa: Instituto de Zootecnia, 1986. p.117196.

PIEKIELEK, W.P.; FOX, R.H. Use of a chlorophyll meter to predict sidedress nitrogen requirements for maize. Agronomy Journal, v.84, n.1, p.59-65, Jan./Feb. 1992.

PIEKIELEK, W.P.; FOX. R.H.; TOTH. J.D. et al. Use of a chlorophyll meter at the early dent stage of corn to evaluate nitrogen sufficiency. Agronomy Journal, v.87, n.2, p.403-408, May/June, 1995.

RAO, I.M.; KERRIDGE, P.C.; MACEDO, M.C.M. Nutritional requiriments of Brachiaria and adaptation to Acid soil, In: MILES, J.W.; MAASS, B.L.; VALLE, C.B. do (Ed.) Brachiaria: Biology, (Agronomy, and Improvement). Cali: CIAT;EMBRAPA, 1996. p.53-71.

REUVENY, Z.; DOUGALL, S.K. \& TRINITY, P.M. Regulatory coupling of nitrate and sulfate assimilation pathways in cultured tobacco cells. Procindings Academic Science, v.77, n.1, p.6670-6672, 1980.

ROCHA, G. L. da. Situação das pastagens no Estado de São Paulo, pastagens naturais e cultivadas. In: CURSO DE MANEJO DE PASTAGENS, 1., Nova - Odessa, 1985. Anais. Nova Odessa: Instituto de Zootecnia, 1985. p.124.

ROCHA, G. L. da. Ecossistema de pastagens: aspectos dinâmicos. Piracicaba: FEALQ, 1991. 391p. 
SALINAS. J.G.; GUALDRÓN, R. Adaptación y requirement de fertilización de Brachiaria humidicola (Rendle) Schweikt en la altillanura plana de los Llanos Orientales de Colombia. In: SIMPÓSIO SOBRE O CERRADO. 6., Brasilia, 1982. Anais. Planaltina: EMBRAPA,CPAC, 1988. p.457-471.

SANCHES, P.A. Suelos del trópicos: caracteristicas e manejo. San José: IICA, 1981. 660p.

SANTOS, A.R.; CORREA, B.D.; MONTEIRO, F.A. Efeito de niveis de nitrogênio sobre o rendimento de matéria seca, teor de nitrogênio e perfilhamento em Panicum maximum cultivar Vencedor. In: CONGRESSO BRASILEIRO DE CIÊNCIA DO SOLO, 25., Viçosa, 1995. Resumos. Viçosa: SBCS;UFV, 1995. p.741-742.

SANTOS FILHO, L. F. Diagnóstico da situação da produção de sementes de plantas forrageiras no Estado de São Paulo. In:ENCONTRO SOBRE PRODUÇÃO DE SEMENTES DE PLANTAS FORRAGEIRAS, 4., São José do Rio Preto, 1990. Anais. São José do Rio Preto: 1990. p.1-14.

SANZONOWICZ, C. Recomendação e prática de adubação e calagem na região centro-oeste do Brasil. In: SIMPÓSIO SOBRE CALAGEM E ADUBAÇÃO DE PASTAGENS. 1., Nova Odessa, 1985. Anais. Piracicaba: Associação Brasileira para a Pesquisa da Potassa e do Fosfato, 1986. p.309-336.

SARRUGE, J.R. Soluções nutritivas. Summa Phytopathologica, v.1, n.3, p.231-233, set. 1975. 
SARRUGE, J.R.; HAAG, H.P. Análises químicas em plantas. Piracicaba: ESALQ, Departamento de Química, 1974. 54p.

SAS INSTITUTE CORPORATION. Propriety software release 6.08. Cary, 1989.

SCHRADER, L.E.; RITENOUR, G.L.; EILRICH, G.L. \& HAGEMAN, R.H. Some characteristics of nitrate reductase from higher plants. Plant Physiology, v.43, n.1, p.930-940, 1968.

SHIRLEY, R.L.; MARIANTE, A. Enxofre na nutrição de ruminantes. In: SIMPÓSIO LATINO-AMERICANO SOBRE PESQUISA EM NUTRIÇÃO MINERAL DE RUMINANTES EM PASTAGENS, Belo Horizonte, 1976. Anais. 1976. p.130-147.

SILVEIRA, J.A.G. Aspectos bioquímicos e fisiológicos da relação $\mathrm{K}: \mathrm{N}$ em canade-açúcar (Saccharum sp) cv.-5679, cultivada em solução nutritiva. Piracicaba, 1980. 127p. Dissertação (Mestrado) - Escola Superior de Agricultura "Luiz de Queiroz", Universidade de São Paulo.

SMEAL, D.; ZHANG, H. Chlorophyll meter evaluation for nitrogen management in corn. Communications in Soil Science and Plant Analysis, V.25, n.9/10, p.1495-1503, 1994.

SMITH, F.W.; SIREGAR, M.E. Sulphur requeriments of tropical forages. In: BLAIR, G. L.; TILL, A.R. (Ed) Sulphur in S.E Asian and S. Pacific agriculture. Armidale: University of New England, 1983. p. 76-86. 
SOARES FILHO, C.V. Recomendação de espécies e variedades de Brachiaria para deferentes condições. In: SIMPÓSIO SOBRE MANEJO DA PASTAGEM, 11., Piracicaba, 1994. Anais. Piracicaba:FEALQ, 1994. p.2548.

SOARES FILHO, C.V.; MONTEIRO, F.A.; CORSI, M. Recuperação de pastagens degradadas de Brachiaria decumbens. 1. Efeito de diferentes tratamentos de fertilização e manejo. Pasturas Tropicales, v.14, n.2, p.16, ago. 1992.

SOUZA, J.C. Composição mineral de capins do gênero Brachiaria em relação a outras gramineas. In: ENCONTRO PARA DISCUSSÃO SOBRE CAPINS DO GÊNERO BRACHIARIA, Nova Odessa, 1986. Anais. Nova Odessa: Instituto de Zootecnia, 1986. cap.4, p.1-23.

SPENCER, K.; JONES, M.B.; FRENEY, J.R. Diagnostic indices for sulphur status of subterranean clover. Australian Journal of Agricultural Reseach, v.28, n.3, p.401-412, May, 1977.

SRIVASTAVA, H.S. Regulation of nitrate reductase activity in higher plants. Phytochemistry, v.19, n.1, p.725-733, 1980.

TAIZ, L.; ZEIGER, E. Plant physiology. Redwood City: The Benjamim/Cumminggs Publishing Company, 1991. Cap. 12, p. 292-317: Assimilation of mineral nutrients.

TISDALE, S.L. Sulphur in forage quality and ruminant nutrition. Washington: The Sulphur Institute, 1977. 13p. 
TISDALE, S. L.; NELSON, J. L.; BEATON, J. D.: Soil fertility and fertilizers. 5. ed. "New York: MacMillan, 1985". 754 p.

TURNER, F.T.; JUND, M.F. Chlorophyll meter to predict nitrogen requiremente for semi-dwarf rice. Agronomy Journal. v.83, n.1, p. 926-928, 1991.

ULRICH, A.; HILLS, F.J. Principles and pratices of plant analysis. In:HARDY G.W. (Ed.) Soil testing and plant analysis. Madison: Soil Science Society of America, 1967, p.11-24. (Special Publication Series).

ULRICH, A.; HILLS, F.J. Plant analysis as aid fertilizing sugar crops: part I. Sugar beets. Principles and pratices of plant analysis. In: WALS, L.M.; BEATON, J.D. (Ed.) Soil testing and plant analysis. Madison: Soil Science Society of America, 1973. p. 271-288.

VALLE, C.B. do.; MILES, J.W. Melhoramento de gramineas do gênero Brachiaria. In: SIMPÓSIO SOBRE MANEJO DA PASTAGEM, 11., Piracicaba, 1994. Anais. Piracicaba: FEALQ, 1994. p.1-24.

VICENTE-CHANDLER, J. Intensive grassland management in Puerto Rico. Revista da Sociedade Brasileira de Zootecnia, v.2, n.1, p.173-215, 1973.

VICENTE-CHANDLER, J.; SILVA, S.; ABRUNÃ, F. \& PEARSON, R.W. Effect of two cutting heights, four harvest intervals and five nitrogen rates on yield and composition of Congo Grass under humic tropical conditions. Journal of Agriculture of University of Puerto Rico, v.56, n.3, p.280-291, 1972. 
VITTI, G.C.; NOVAES. N.J. Adubação com enxofre. In: SIMPÓSIO SOBRE CALAGEM E ADUBAÇÃO DE PASTAGENS, 1., Nova Odessa, 1985. Anais. Piracicaba: Associação Brasileira de Pesquisa da Potassa e do Fosfato, 1986. p.191 - 231.

WERNER, J.C. Adubação de pastagens. Nova Odessa: Instituto de Zootecnia, 1986. 49p. (IZ. Boletim Técnico, 18).

WERNER, J.C.; MONTEIRO, F.A. Respostas das pastagens à aplicação de enxofre. In: SIMPOSIO: ENXOFRE E MICRONUTRIENTES NA AGRICULTURA BRASILEIRA, Londrina, 1988. Anais. Londrina: EMBRAPA,CNPS;IAPAR, 1988. p.87-102.

WERNER, J.C.; QUAGLIATO, J.L.; MARTINELLI, D. Ensaio de fertilização do colonião com solo da "Noroeste". Boletim de Indústria Animal, v.24, n.1, p.19-167, 1967.

YADAVA, U.L. A rapid and nondestructive method to determine chlorophyll in intact leaves. HortScience, v.21, n.6, p.1449-1450, Dec. 1986. 